Louisiana State University

LSU Digital Commons

1969

\title{
Economic Aspects of Ground-Water Basin Control.
}

Laurence Henry Falk

Louisiana State University and Agricultural \& Mechanical College

Follow this and additional works at: https://digitalcommons.Isu.edu/gradschool_disstheses

\section{Recommended Citation}

Falk, Laurence Henry, "Economic Aspects of Ground-Water Basin Control." (1969). LSU Historical Dissertations and Theses. 1588.

https://digitalcommons.Isu.edu/gradschool_disstheses/1588

This Dissertation is brought to you for free and open access by the Graduate School at LSU Digital Commons. It has been accepted for inclusion in LSU Historical Dissertations and Theses by an authorized administrator of LSU Digital Commons. For more information, please contact gradetd@lsu.edu. 
This dissertation has been microfilmed exactly as received

$70-235$

FALK, Laurence Henry, 1929ECONOMIC ASPECTS OF GROUND-WATER BASIN CONTROL.

The Louisiana State University and Agricultural and Mechanical College, Ph.D., 1969 Economics, general

University Microfilms, Inc., Ānn Arbor, Michigan 
ECONOMIC ASPECTS OF GROUND-WATER BASIN CONTROL

A Dissertation

Submitted to the Graduate Faculty of the Louisiana State University and

Agricultural and Mechanical College

in partial fulfillment of the

requirements for the degree of

Doctor of Philosophy

in

The Department of Economics

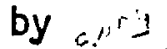

Laurence H. Falk

B.S.B.A., University of Denver, 1952

May, 1969 


\section{ACKNOWLEDGMENT}

This writer is happy to acknowledge the assistance and encouragement given him by many people at different stages of this work. A sincere thanks is due to the members of his committee, Professors W. J. Stober, J. P. Payne, R. F. Smith, W. F. Campbell and P. F. Boyer for their constructive criticism of this dissertation. In particular, the writer would like to thank Professor W. J. Stober, who patiently directed the research and gave very generously of his time and ideas during the preparation of the manuscript. Responsibility for any errors or opinions are assumed by this writer, of course.

Appreciation is sincerely extended to Professor R. G. Kazmann, Associate Director of the Louisiana Water Resources Research Institute, for his guidance in general, and for his clarification of parts of the study pertaining to ground-water hydrology in particular. The writer is also most grateful to the following: Louisiana Water Resources Research Institute at Louisiana State University; the East Baton Rouge City-Parish Council and the Federal Office of Water Resources Research whose matching grants under P.L. 88-379 made this work possible; Mr. Clinton Milne of the Los Angeles Flood Control District, Mr. Max Bookman of the Central and West Basin Water Replenishment District of Los Angeles County, and Mr. Frank Thill of the California Taxpayers' Association who personally answered many of the writer's questions concerning water facilities and taxation in the Los Angeles Area; Mr. Sam Roy, 
fellow doctoral candidate, for his helpful advice on several parts of the manuscript; and Mrs. Leila Cutshaw for her help on the water law portions of the study.

Finally, the assistance, encouragement and sacrifices of my wife, Sylvia, are noted with the greatest measure of gratitude and affection. 
TABLE OF CONTENTS

Page

ACKNOWLEDGMENT ...................

LIST OF TABLES ............................. vi

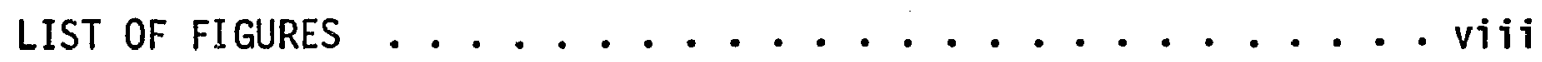

ABSTRACT ......................... ix

Chapter

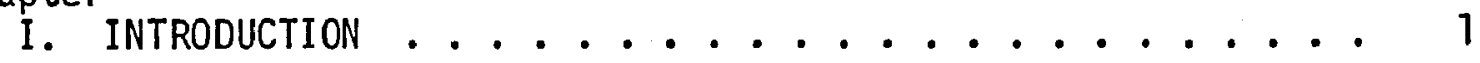

Purpose and Scope................

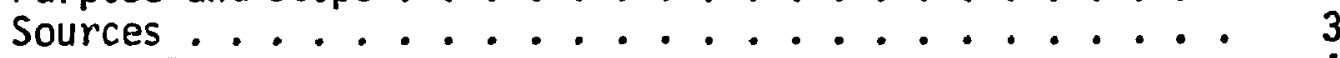

Study Plan ..................... 4

Ground-Water Hydrology ............ 6

The Hydrologic Cycle ............ . . 6

The Complete Cycle .............. 9

Ground Water ............... . . 12

Total Water Demand and Supply. . . . . . . . 13

The Myth of Water Shortage ............ 15

Glossary and Measurements ........... 16

II. ALLOCATION OF EXISTING SUPPLIES ............ 19

Water Law in the United States .......... 21

The Riparian Doctrine ............ . 21 21

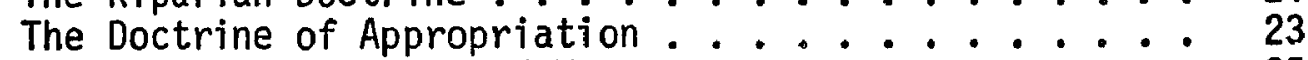

Inters tate Regulation of Water ......... 25

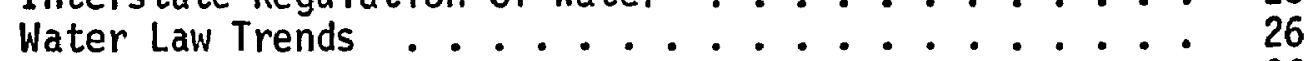

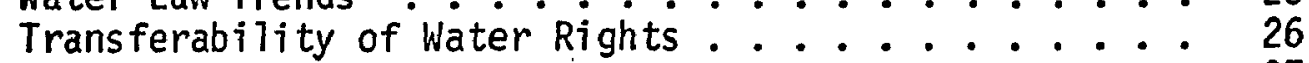

Summary ..................... 27

Optimal Allocation of Water ............. 28

Impediments to Market Optimization ....... 30

Free Market or Adminis trative Controi ........ 33

An Evaluation of Existing Water Laws ....... 34

The Use of Flat Rates ............ 35

Summary of Chapter ............... 38

III. DECISIONS TO AUGMENT EXISTING SUPPLIES ........ 41

Criteria for Choice ............ 43

Benefit-Cost Ratios.......... 43 
Application of Benefit-Cost Ratios ......... 45

The Present Value of Future Costs.......... 48

Appropriate Rates of Discount ........... 51

Present Value Unit Cost: Community Project . . . . . 59

Present Value Unit Cost: Corporate Alternative . . . 60

The Non-Profit Community Project Unit Costs . . . . . 69

Corporate Project Unit Costs ........... 70

A Comparison of Costs............. 73

Benefit-Cost Ratios ............... 76

Public Investment Criteria and National Economic

Welfare................ 79

The Appropriate Social Discount Rate . . . . . . 80

Market Rate of Interest ............... 83

The Conservationist Viewpoint . . . . . . . . . 84

Dual Individual Time Preference Rates . . . . . . . 84

Other Views on the Discount Rate . . . . . . . . 86

Application to Local Project Analysis . . . . . . . 88

Conclusions ..................... 89

IV. THE CENTRAL AND WEST COASTAL BASINS OF LOS

ANGELES: A CASE STUDY ............. 92

Ground Water ............... . . 98

Costs to Water Users ................ 101

Direct Costs to Ground-Water Users ......... 101

Indirect Costs to Ground-Water Users . . . . . . . 102

Average Total Costs of Ground Water ........ . 104

Social Cost of Ground Water ............ 110

Imported Water .................. 116

Cost to Water Users .............. 119

Social Cost of Imported Water ............ 122

Conjunctive Use and the Transfer of Water Rights . . . 133

West Bas in Exchange Pool ........... . . 134

Central Basin Exchange Pool . . ......... 136

Transfer of Rights and Economic Efficiency ... ... 136

Permanent Sale of Water Rights .......... 140

Optimal Conjunctive Use . . . . . . . . . . . . . 141

Social and Private Marginal Cost Discrepancy . . . . 142

Private Marginal Cost Discrepancies... . . . . . 143

Requirements for Efficiency Restoration ....... 146

Adjudication vs. Use Charges ........... 154

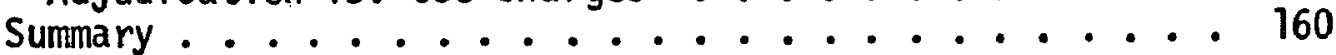


v. SUMMARY AND CONCLUSIONS .............. 162

Allocation of Existing Water Supplies ........ 163 Supplementing Local Water Supplies ......... 165 A Case Study ............... 166

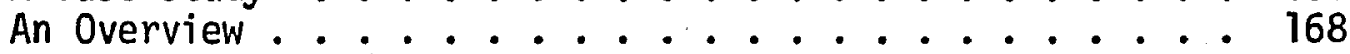
BIBLIOGRAPHY OF REFERENCES CITED . . . . . . . . . 170

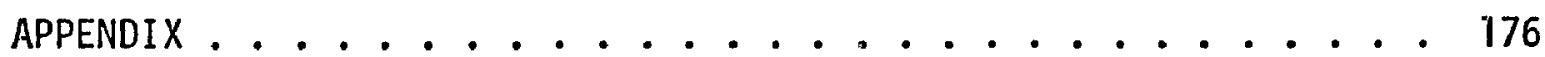

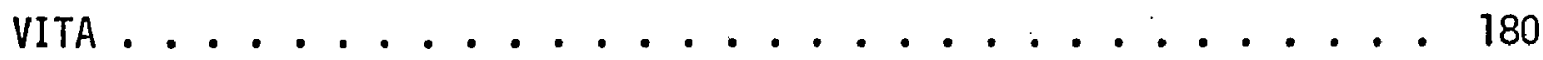




\section{LIST OF TABLES}

Table

Page

3-1 Community Project: Water Costs at Selected Rates of Discount ............ 70

3-2 Corporate Project: Water Costs at Selected Rates of Discount .............. 72

3-3 Corporation Cost of Water: Comparison between Producing Its Own Supply and Purchasing from the Community Project at Selected Rates of Discount...

3-4 Corporation's Savings, in Dollars per Acre-Foot, Resulting from the Purchase of Water from the Community Project at Different Rates of Discount . . . 75

4-1 Average Total Water Costs to Ground-Water Producers-M.W.D. Tax $\$ 0.14$ per $\$ 100^{\circ}$ (Dollars per Acre-Foot) . . 105

4-2 Average Total Water Costs to Ground-Water Producers-M.W.D. Tax $\$ 0.27$ per $\$ 100$ (Dollars per Acre-Foot) . . 106

4-3 Total and Average Variable Social Cost of Ground Water in the West and Central Basin Replenishment

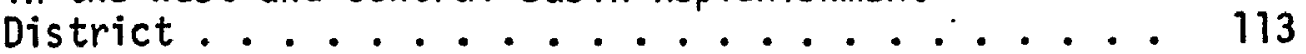

4-4 Metropolitan Water District Rate History (Dollars per Acre-Foot) .......... 118

4-5 Average Total Cos ts of Imported Water to West Bas in Water Users--M.W.D. Tax $\$ 0.14$ per $\$ 100$ (Dollars

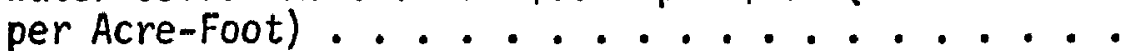

4-6 Average Total Costs of Imported Water to West Bas in Water Users--M.W.D. Tax $\$ 0.27$ per $\$ 100$ (Dollars per Acre-Foot) . . . . . . . . . . .

4-7 M.W.D. Rates for Untreated Water for Agriculture and Replenishment in 1965 Dollars ........ 


\section{LIST OF FIGURES}

Figure

Page

1-1 Average Annual Precipitation (Inches) in the United

States for the Period 1899-1938........ 10

1-2 The Hydrologic Cycle . . . . . . . . . . . . 11

2-1 The Effect of Charging Flat Rates for Water . . . . . 37

3-1 Community Project Benefit-Cost Ratios Assuming Constant Returns to Outlay ............

4-1 Central and West Bas in Water Replenishment District, Los Angeles County, California ......... 95

4-2 Ground-Water Cost Curves--Central and West Basin Replenishment District . . . . . . . . . . 111

4-3 Ground-Water Demand--Central and West Basin Replenishment District ........... 115

4-4 Metropolitan Water District Adjusted Total Costs and Adjusted Output, 1946-1965

(Quantity, 1964-65 = 100; Price $1965=100$ ) .... 125

4-5 Metropolitan Water District, First Differences of Adjusted Total Costs and Adjusted Output, 1946-1965 (Quantity, 1964-65 = 100; Price 1965 = 100) .... 127

4-6 Transfer of Rights through Exchange Pools . . . . . . 138

4-7 Losses Resulting from Overproducing or Underproducing

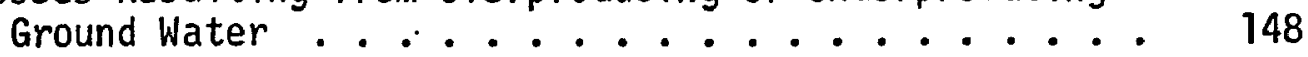

4-8 Ground-Water Costs at Various Output Levels . . . . . i52

4-9 Immediate Effect of an Increase in Individual Ground-Water Rights............. 156

4-10 Rationing of Ground-Water Rights by Variations in Pumping Charges ................ . 


\section{ABSTRACT}

In recent years economists have been giving increasing attention to the problems associated with water resource development. Quite logically, most of the work has been done in areas where very large ex-

penditures have been involved--in studies of flood control, navigation, irrigation and hydro-electric projects. Usually the projects studied involved expenditures by the federal government.

Expenditures on water resources at the local level have been largely neglected, and when they have been examined the viewpoint has not buen that of the local community itself. Rather, the studies have taken the national view, hence the decision rules which have been used are those which have been developed to evaluate federal projects.

The major objective of this research has been to devise an economic model for use in deciding among alternative local groundwater basin projects from the point of view of the local community itself. A subsidiary goal has been to examine the effect on national welfare of the local community's use of the decision-making model.

The economic model incorporates benefit-cost analysis. The relevant cost of any local water project proposal is the present value. unit cost obtained by discounting the costs incurred over time by the community's cost of capital. Benefits are measured by the costs avoided by undertaking the project, thus, if the alternative to the project is inaction, the benefits are the costs of inaction. 
As an alternative to a community project private water-using companies may undertake projects to secure their own water supplies. Then the benefit to use in evaluating the community project is the present value unit cost of the corporate project determined by discounting costs incurred over time by the corporate cost of capital. The results of a hypothetical comparison between a corporate project and a non-profit community project show that, with constant returns to scale and equal costs of capital, the present value unit cost of water is less for the corporate project than for the community project. The benefit-cost ratio will favor the community project, however, because the after-tax cost for a corporation purchasing water from the non-profit project is lower than the present value unit cost of the corporate project. It is therefore to the advantage of the community to undertake the non-profit project. This conclusion is very unlikely to be overturned by either differences in costs of capital or by diseconomies of scale.

The community decision-making model is found likely to be nonoptimal from the national welfare viewpoint. This is largely a result of the corporate income tax structure, and correction of resultant misallocations would require changes in the tax laws.

A case study of ground water-imported water conjunctive use in the Los Angeles area reveals several economically inefficient practices. Ad valorem taxes are used to finance ground-water variable costs, thus, for all practical purposes, transforming them into fixed costs 
even in the long rur. This results in misallocations of ground water. Simultaneously, some water users are using imported water which costs them more than the unit ground-water cost. This is a further violation of economic efficiency conditions. The cost differentials persist because the market in ground-water rights is imperfect.

It is concluded that economic efficiency could be improved in the study area by eliminating certain ad valorem taxes and including the costs they now cover in user charges, and by eliminating adjudicated water rights, instead allowing anyone to pump any desired quantity of water. Pumping charges would be assessed to bring the marginal cost of ground water up to the cost of the imported water substitute. 


\section{CHAPTER I}

\section{INTRODUCTION}

\section{Purpose and Scope}

In recent years a great deal of attention has been devoted to the development of water resources at the federal level. Investments in water resources at the state and local level, however, have been largely ignored. When local projects have been investigated the analytical procedure which has been adopted has been much the same as that used to analyze federal projects. Hirshleifer et al. (1960), for example, study the problems of New York City and Los Angeles using the approach that they deem appropriate for the budgeting of funds for federal water projects. While their analys is may shed much light on the welfare effects of local projects from the national point of view, and while it may also show that "poor" water investment decisions are being made at the local level, the model that is used for choosing among alternatives does not actually reflect how the community itself might look at the problem.

It is the primary objective of this study to develop an economic model which may be used in deciding among alternative groundwater basin control measures. The point of view adopted is that of the locality itself.

A secondary goal is to examine the effect on national welfare 
of using the local decision-making model in choosing among alternative water projects. An analysis is presented of the factors which may cause local water projects to be selected that are not optimal for the nation, but no attempt is made to suggest policy measures which would close the gap between the local and national interests.

A hypothetical numerical example is utilized to illustrate how a local community might use the model. Parameters are then varied to demonstrate the model's sensitivity to factors which cannot be precisely determined. These sensitivity tests show that ignorance of the exact parameter values is not a serious problem. Under normal conditions the model will point unambiguously to the decision which is optimal for the local community.

A case study of ground-water basin control measures is undertaken to illustrate the problem that one municipal water district, the Central and West Basin Water Replenishment District of Los Angeles, has encountered in establishing a ground water-surface water conjunctive use system. A number of economicaliy inefficient practices are noted, and corrective procedures are suggested. It is not the intent of this study, however, to recommend that the District make changes in its operations. Rather, the purpose of the case study is to demonstrate the importance of considering economic effects in the management of ground-water basins. 


\section{Sources}

A search of the rapidly growing body of water resources literature indicated that certain problens which significantly affect local water supply decisions have been neglected. A local community considering an addition to its water supply must answer the question: Should private firms, perhaps including private water utilities, be left to augment their own supplies, or should the community itself undertake the project? In answering the question the authorities of the community would have to consider three complications: (1) the effect of corporate income taxes on project proposals, (2) the effect of differences in community and corporate costs of capital, and (3) the effect of economies or diseconomies of scale on project costs. Such problems have received inadequate attention in the literature.

To determine the effect of corporate income taxes it was necessary to search the literature in the areas of managerial economics, corporate finance, and taxation. The newer texts in the area of capital budgeting and the standard reference works on taxation were found to be quite usefut.

The case study of the Central and West Basin Water Replenishment District of Los Angeles was made with data obtained from reports of the District, publications of the California Department of Water Resources, the Los Angeles County Taxpayer's Guide, and the Metropolitan Water District Annual Report for each fiscal year from 1938 through 1966. 
Mich of the background information used in the case study was gathered during a field trip to Los Angeles in June, 1966. A number of people, directly involved in the management of the area's water supply, were interviewed at that time. Follow-up interviews were made by telephone and later in person, when several people from Los Angeles area water agencies traveled to Louisiana State University to participate in a symposium on salt-water encroachment into aquifers.

An understanding of existing ground-water laws was necessary background information for both the local decision-making model and the Replenishment District case study. The Louisiana Water Resources Research Institute recently published a handbook on water law (Hardy, 1966), and the bibliography developed for that study by Mrs. Leila 0 . Cutshaw provided the basis for most of the discussion on ground-water law.

\section{Study PJan}

Following a brief and elementary treatment of the basic principles of hydrology in Chapter I, the question of allocating existing water supplies is examined in Chapter II. The basic doctrines that underlie water laws in the United States, particularly in their application to ground water, are discussed in the context of their effect on economic efficiency. Efficiency implications of flat rate water pricing are also briefly treated.

A model for choosing among local water project alternatives is developed and applied with a numerical example in Chapter III. The 
results of using the model are discussed from a welfare standpoint and, in this connection, some of the divergent views on the social rate of discount are summarized.

Chapter IV is a case study of the water supply procedures of the Central and West Basin Water Replenishment District of Los Angeles. Arrangements used to finance the District's ground water production costs are criticaliy evaluated against the background of estimated average and marginal costs. Average and marginal cost calculations for imported water follow, and the method of pricing imported water is analyzed. It is shown that existing pricing and financial arrangements lead to an inefficient use of both ground water and imported water. The criteria for efficient ground water-imported water conjunctive use are then established.

Three major conclusions are 1 isted in Chapter $V$, the final chapter. First, it is noted that extant water laws tend to cause misallocation of the nation's water resources. The establishment of firm and tradeable water rights would be an improvement in most instances; however, another approach is suggested for the study area because of uncertainty about the future costs of an imported water supply. Second, it is concluded that a community may undertake a project that is optimal from its own standpoint, but the result for the nation as a whole may be misallocated resources. Third, the inefficient practices found in the case study are thought to result, in part at least, from the existing water laws which reward 
premature appropriation of supplies.

\section{Ground-Water Hydrology}

Ground-water hydrology is a relatively new science. Its development had to await the discovery of the fundamental principles of geology near the end of the eighteenth century. Although water wells had been in use since ancient times, man's prior concept of the origin of ground water was a curious mixture of superstition and faulty deduction. In recent years the study of ground-water hydrology has advanced significantly. Its rapid gains are not only the result of extensive data gathering in the field of hydrology itself, but they have also been fed by the explosion of knowledge in botany, chemistry, physics, meteorology and other sciences (Jones, et al., 1963, pp. 11-19).

The occurrence of ground water in nature can best be understood in the context of the hydrologic cycle--"the endless circulation of water from the primary reservoir, the ocean, to the atmosphere, the land, and back to the ocean over or beneath the land surface" (U.S. Geological Survey, 1963, pp. 10-11). Accordingly, a brief discussion of the hydrologic cycle is presented below.

The Hydrologic Cycle

Although the hydrologic cycle has neither a beginning nor an end, its description usually begins with the oceans which cover more than 70 percent of the earth's surface. The sun's heat evaporates water from the oceans into the atmosphere. Normally the vapors are 
invisible as they leave the ocean surface, but under the proper conditions they form visible clouds. When certain additional conditions are satisfied the moisture contained by clouds condenses and falls back to earth as some form of precipitation--rain, hail, sleet or snow. These various forms of precipitation are collectively called "water of meteoric origin" (Johnson, Inc., 1966, p. 15).

On the average about 30 inches per year of precipitation fall on the 48 conterminous states of the United States. This represents an abundant metecric water supply compared to that of other nations (U.S. Geological Survey, 1963, p. 10). But the characteristics of the hydrologic cycle make for a very irregular distribution of water in space as well as in time.

Most of the water which evaparates from the oceans precipitates again on the oceans. That which falls on land, along with some landderived moisture, is precipitated in response to three phenomena: (1) the movement of large masses of warm, moisture laden air into regions of cold air, (2) the warming of air at the earth's surface which causes it to rise in large masses into overlying cold air, and (3) the cooling of the air masses in the winds blowing across high mountain barriers (Davis and De Wiest, 1966, pp. 17-18).

Meteoric water occurs quite irregularly with respect to geography. The land surfaces nearest the oceans have the greatest opportunity for receiving precipitation. In the northern hemisphere the prevailing winds are westerly, hence it is convenient to begin with 
the West Coast in generalizing about the United States precipitation pattern. Evaporated water from the Pacific Ocean is carried by the westerlies to the coast. High coastal ranges force the warm and more or less water saturated winds to rise and cool. As a result part of the moisture contained in the air condenses and falls as some form of precipitation. More precipitation falls in the cooler northern states. Some parts of Washington, in the Coast and Cascade Ranges, receive in excess of 100 inches annually. But, north or south, precipitation varies directly with the height of the mountain barriers. As the air masses move down the coastal ranges they are again warmed and the opportunity for precipitation is substantially lessened. Desert conditions are found between the coastal range of Southern California and the Sierra Nevada.

The procedure is repeated as the winds move over the high Sierras. Precipitation increases substantially on the upslope and decreases as the air moves downward into the "rain shadow" between the Sierras and the Rockies. Meteoric water again increases as the air moves upward to the Continental Divide and another, less pronounced, rain shadow is seen to the east of the Rocky Mountains. Farther to the east, precipitation is influenced by the Pacific, the Gulf of Mexico and the Atlantic. Lands lying closest to the warm Gulf waters receive the most precipitation, and in general more precipitation is found near the Gulf and Atlantic coasts than farther inland (U.S. Geological Survey, 1963, pp. 10-12). Figure 1-1 is a map showing average annual 
precipitation in the conterminous United States over a 40-year period. The effects of mountain ranges--Coastal, Sierras, Rockies and Appalachians--are clearly seen on the precipitation "contours".

\section{The Complete Cycle}

of the 30 inches average of water that falls on the United States the major portion--approximately 21 or 22 inches--is vaporized. The remainder appears on or below the land surface (Kazmann, 1965, p. 4). Some evaporation of water, not included in the 30-inch average precipitation figure, occurs in the air between the clouds and the land surface. The remaining evaporation takes two forms: (1) direct evaporation from wet surfaces, and (2) transpiration through plants from their leaves and stems. Precipitation adhering to trees and other vegetation, which is called "intercepted water," accounts for a large portion of total evaporation (De Wiest, 1965, pp. 15, 37-50). Collectively, evaporation and transpiration are called "evapotranspiration." The 8 or 9 inches not returned to the atmosphere in a vaporous form, except the evaporation from surface channels, is termed "runoff." Runoff approximates the nation's. potential available water supply, if conversion of sea water to fresh water and other recent technological advances are ignored. While runoff eventually appears on the surface as streams, it is not solely a surface phenomenon since it includes ground water discharge.

Ground water formation results from percolation of precipitation through permeable soil. The force of gravity moves ground water 


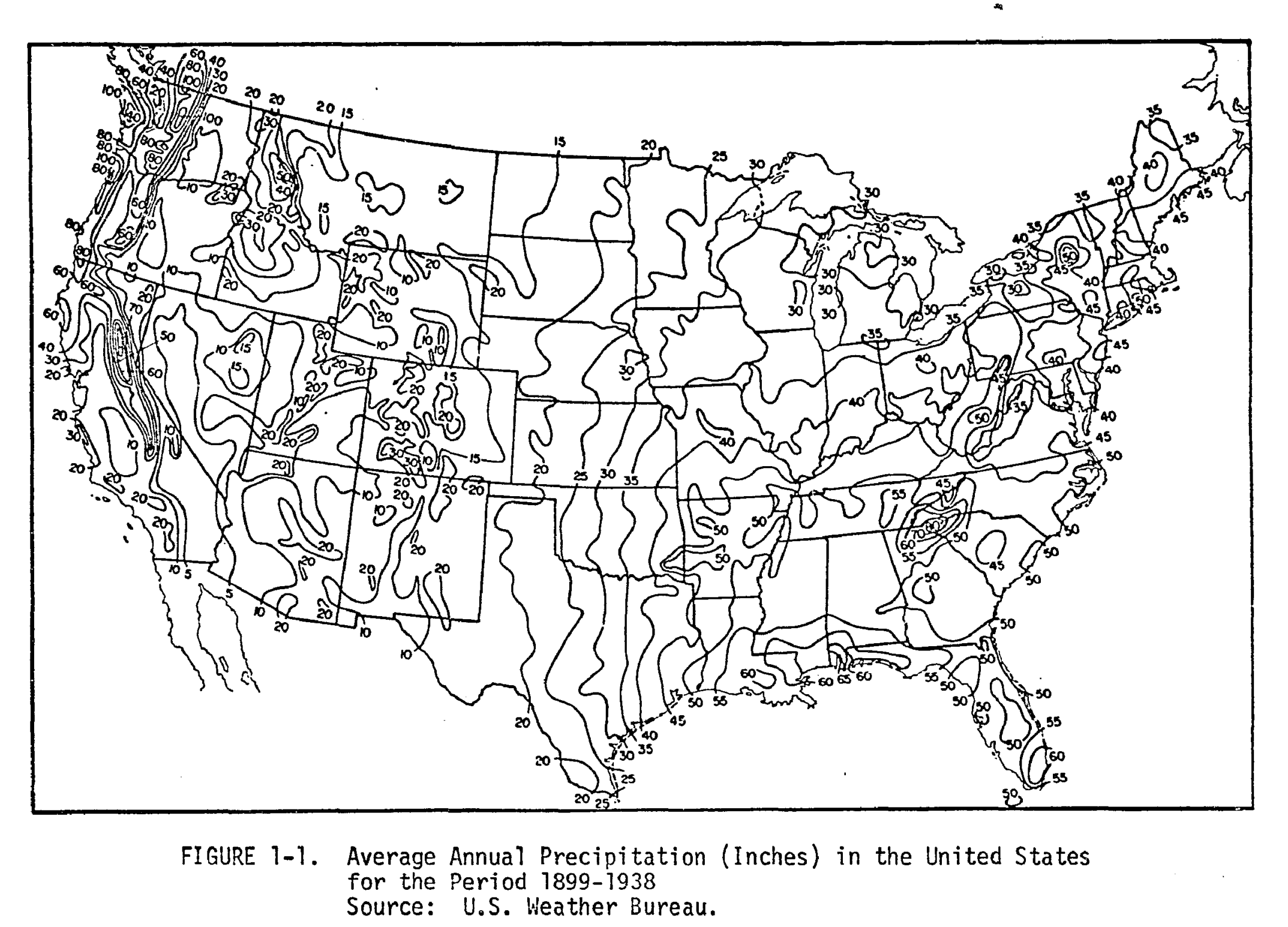




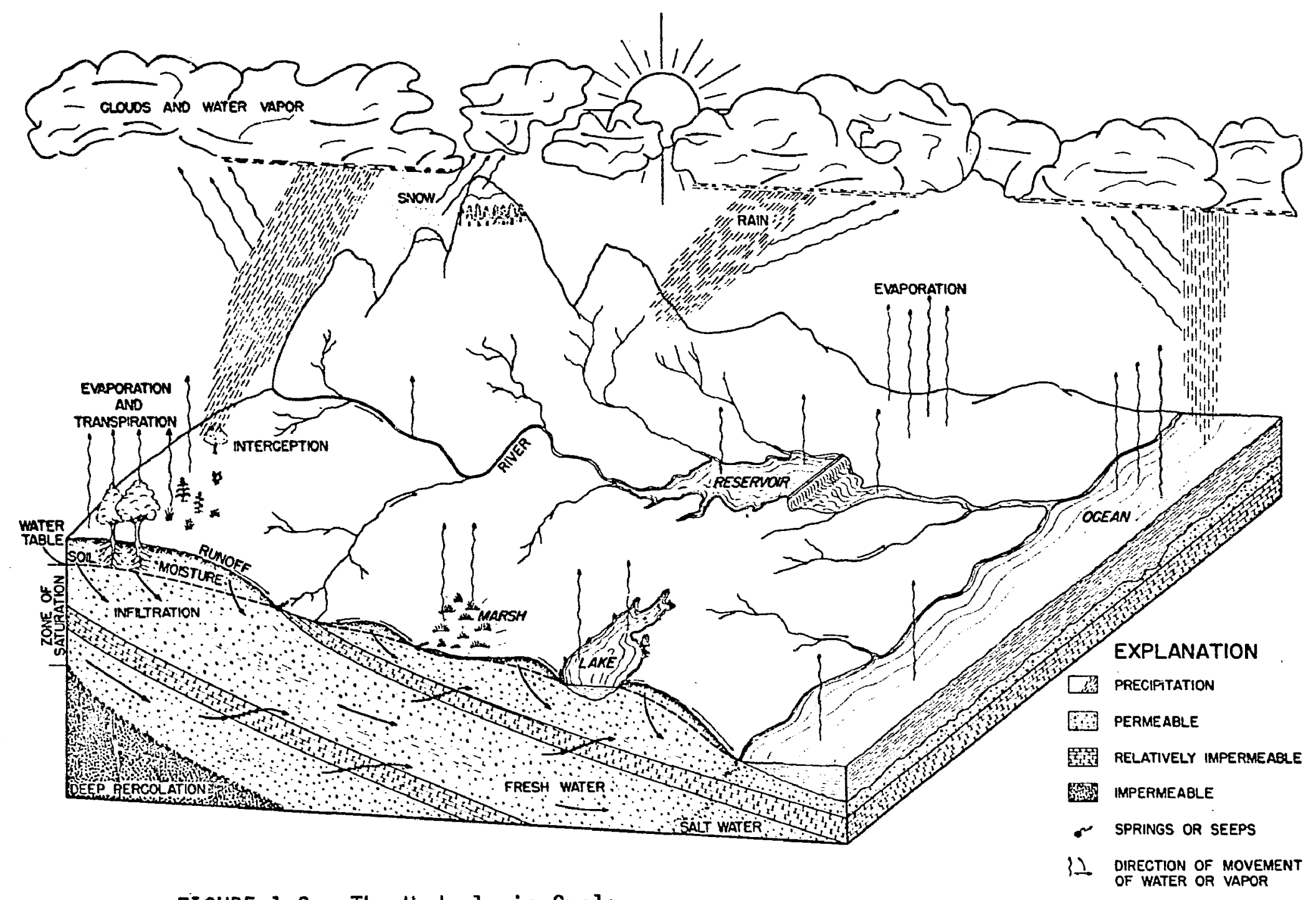

FIGURE 1-2. The Hydrologic Cycle

Source: Texas Water Commission

(Reproduced by permission). 
down-dip through alluvial deposits, or through porous rock, gravel or sand lying between relatively impermeable strata. Ultimately the ground water may reappear at the surface in artesian springs or seeps, or it may discharge below sea level to the oceans. Much the larger part of ground water discharge reaches surface streams, a fact which keeps them flowing even during dry periods (U.S. Geological Survey, 1963, pp. 10-16). The streams and rivers, of course, flow downhill into the oceans. The discharge to the oceans of over $90 \%$ of total runoff completes the cycle (Hirshleifer et al., p. 19). Figure 1-2 is a schematic drawing of the hydrologic cycle in its entirety.

\section{Ground Water}

Ground water is becoming an increasingly important water supply source. It is a surprising fact that less than $3 \%$ of the world's available fluid fresh water occurs in streams and lakes. Because we see and hear a great deal about large and expensive surface water projects, we tend to think of surface water as the largest potential source of supply, but $97 \%$ of the earth's water inventory lies underground (Johnson, Inc., 1966, pp. 5-6). Underground flow comprises an estimated 33 to $40 \%$ of this nation's total runoff on the average, and the average is greatly exceeded in certain areas (Hirshleifer et al., 1960 , p. 19). Not all of the ground water is available at a currently economical cost, however, hence 81 percent of the present United States water supply is drawn from surface sources. Nevertheless, five states-- 
Arkansas, Arizona, Mississippi, New Mexico and South Dakota--depend on ground water for over half of their total water supplies. Eight other states--California, Florida, Iowa, Kansas, Nebraska, Oklahoma, Texas and Vermont---use ground water for between 25 and 50 percent of their water use, and in another 13 states ground water supplies 10-25 percent of total needs (Todd, 1959, pp. 6-8).

Total Water Demand and Supply

The present supply of usable water in the conterminous United States is roughiy equivalent to the average runoff of some 1,200 billion gallons per day. In 1960 total water withdrawals amounted to 270 bgd or 22 percent of the total (U.S. Geological Survey, 1962, pp. 1-26). Of the total withdrawals, however, consumptive use accounted for only 60 bgd, thus 210 bgd was returned to watercourses and available for further use. In 1961, the U.S. Senate Select Committee on Water Resources estimated that water withdrawals would total about 559 bgd in 1980 and that consumptive use would be approximately $190 \mathrm{bgd}$. By 2000 withdrawals and consumptive use are projected to be 888 bgd and $253 \mathrm{bgd}$ respectively. To find the total quantities of "streamflow required" the minimum quantity needed for acceptable pollution abatement must be added to the consumptive use figures. Thus water demand is expected to total $523 \mathrm{bgd}$ in 1980 and $700 \mathrm{bgd}$ in 2000, with ground water providing an increasing proportion of the total supply. The estimated demand for the year 2000 is nearly 60 percent of the total available supply, and the rate of increase in demand, if continued, 
would outstrip the available supply during the next century (U.S. Geological Survey, 1963, pp. 79-85).

The country's supply of water may be considered untimited, however, for a number of reasons. The usable water supply can be increased without limit, for all practical purposes. First, a large part of what is now considered "consumptive use" is "consumptive" only because the facilities do not exist to reclaim the water. Sewage water can be treated and reused. Second, evapotranspiration is now responsible for a significant amount of consumptive use of water. Water-loving plants, or phreatophytes, grow on the edges of water courses or the shores of reservoirs. Control of these phreatophytes has already resulted in some reduction in water wastage. Further savings can be effected by controlling evapotranspiration in agricultural irrigation. Much is already known about the adaption of crops to water consumption constraints. Evaporation suppression on reservoirs, by any of a number of methods of reducing water surface exposure, also holds promise. Third, improved irrigation methods can

$\because$ be applied to reduce seepage and conveyance losses. Fourth, weather modification may add considerably to usable water supplies at some future date. Finally, a number of methods have been developed for converting sea water to fresh water, although the present cost is still prohibitively high where almost any alternative source of water is available (Ackerman, 1965, pp. 450-67; U.S. Geological Survey, 1963, pp. 93-100). 
The Myth of Water Shortage

It is frequently stated that the United States is suffering, or will suffer, from a severe water shortage in the near future unless immediate conservation measures are undertaken (Carhart, 1959, pp. 13-29). In the preceding section, however, the opposite conclusion was drawn, but to say that the supply of water is virtually unlimited is to leave part of the story untold. It must also be recognized that additional supplies of water can be obtained only by putting increasingly large amounts of our resources into water production. Conversion of sea water to fresh water, which is now feasible, could take care of man's water requirements forever. The unit cost of desalinization of water, however, is presently many times higher than the unit cost of water produced by other methods. As of 1962, the cost of desalting seawater stood at nearly $\$ 400$ per acre-foot, or considerably over one doilar per thousand gallons (Linsley and Franzini, 1964, p. 440). In contrast, evaporation of fresh water can be prevented by spreading a one-molecule thick substance, such as cetyl alcohol, on its surface for about $\$ 40$ per acre-foot or one-tenth the cost of desalinization (U.S. Geological Survey; 1963, pp. 93-94). At present, however, even this procedure costs a great deal more than the normal unit cost of producing water. In Chapter IV, for example, it is shown that average total cost of Colorado River water, delivered through a 242-mile long aqueduct and then softened and filtered, has recently been fully covered by charging no more than $\$ 40$ per acre-foot. 
And this source is probably among the most expensive being used in the United States today.

In summation, while it may be said that there can be no such thing as a "shortage" of water, it must be recognized that water will become more costly as future demands increase. This nation can obtain all the additional water which its people may desire, as long as its people are willing and able to pay the rising cost.

Glossary and Measurements

It should be helpful, at this point, to define some technical terms and to provide some measurement conversions which appear in the chapters to follow. (Milne, 1968, pp. 143-44; Jones et al., 1963, pp. 33-35).

Acre-foot. The volume of water required to cover one acre to a depth of one foot.

Alluvium. Soil or earth material that has been deposited by running water or floods.

Aquifer. A strata, formation, or group of formations, which are porous, permeable, and water-bearing and have hydraulic continuity. Artesian (or Pressure) Aquifer. A confined aquifer in which the water is under a pressure that is sufficient to cause the water to rise above the bottom of the overlying and impervious confining bed. 
Fault. A fracture or fracture zone in the earth along which strata are displaced. The displacement may result in an aquifer being cut-off from the water source.

Forebay. An area containing unconfined ground water and which has hydraulic continuity with the ground surface.

Ground Water. Subsurface water that occurs in, and moves through, an aquifer.

Ground-Water Basin. A ground-water storage area. Hydraulic Gradient. The line joining the elevations to which water would rise in wells that are screened in the confined aquifer. Hydrology. The applied science concerned with the waters of the earth's hydrologic cycle of precipitation, storage, infiltration, evaporation, runoff and disposal of water.

Percolation. The movement, under hydrostatic pressure, of water through the pores of rock or soil.

Permeability. The ability of a material to transmit a fluid through its pores under given conditions.

Piezometric Surface. An imaginary surface that everywhere coincides with the static level of water in an aquifer or artesian basin. It is the surface to which the water in the aquifer or basin would rise if afforded the opportunity to do so.

Pressure Area. A ground surface area underlain by an aquifer containing confined ground water. 
Transmissibility, Coefficient of. The amount of water in gallons per day which will pass through a one-foot wide vertical strip of the aquifer under a hydraulic gradient of one foot per foot.

Selected Water Measurement Values

Area:

1 acre $=4.356\left(10^{4}\right)$ sq. $\mathrm{ft}$.

1 sq. mile $=640$ acres.

Volume:

1 million gal. $=3.07$ acre-ft.

1 thousand gar. $=3.07\left(10^{-3}\right)$ acre-ft.

1 million acre-ft. $=3.259\left(10^{5}\right)$ million gal.

1 acre-ft. $=3.259\left(10^{5}\right)$ gal .

Discharge:

1 acre-ft. per day $=2.26\left(10^{2}\right)$ gal. per min.

1 acre-ft. per day $=3.26\left(10^{-1}\right)$ million gal. per day.

1 acre-ft. per day $=5.05\left(10^{-1}\right)$ cubic ft. per sec.

Miscellaneous:

1 ft. water $=0.4335$ lbs. per sq. in.

To 1 ift 1 gal. water $1 \mathrm{ft}$. requires $3.15\left(10^{-6}\right)$ kilowatt-hours. 


\section{CHAPTER II}

\section{ALLOCATION OF EXISTING SUPPLIES}

Water is an economic good or resource which exhibits the essential qualities of all other economic goods or resources. It is quite clear from the facts presented in Chapter I that water exists abundantly in nature. Nevertheless it is also clear that water supplies can be obtained for human use only through the application of varying amounts of scarce resources. Like the production of other economic goods water production must eventually obey the law of diminishing returns. For any given location and for any given state of water production technology, increased water output is ultimately associated with increasing marginal and average costs. One locality may experience falling costs for production from one source but resorting to new sources results in rising marginal and average costs in the long run (Hirshleifer et al., 1960, pp. 95-96). Society may develop additional water supplies, if it desires, but only by paying higher unit costs. If scarce resources are diverted to additional water production, society will gain only if it values the additional water more than it values the production of the other economic goods foregone as a result of the resource diversion.

It may seem trivial to point out that water is like other economic goods, yet historically this fact has apparently never been 
clearly understood. Indeed, economists themselves have not always recognized the relationship between water and other economic goods. Furthermore, there is ample evidence that today's professionals who are charged with obtaining or allocating water supplies, feel that, somehow, "water is different."

The misunderstanding probably springs from two bits of knowledge: (1) that water is in abundant supply, and (2) that man cannot survive without a source of water for drinking and other purposes. These observations evidently prompted Adam Smith to distinguish between "value in use" and "value in exchange" in the famous "diamondwater paradox" passage from his Wealth of Nations (Smith, 1776, p. 28). Smith supposed diamonds to have market value but no value in use, and water to have a high value in use but no value in the market place. The second fact, that man cannot live without water, has been largely responsible for laws which have elevated water above other economic goods.'

The objectives of this chapter are threefold. First, a brief exposition of existing water laws is presented with emphasis placed on state laws as they pertain to ground-water production. Second, the conditions for optimal allocation of water resources are discussed, and some of the present water laws are shown generally to violate

The U.S. Supreme Court's recognition that "water is a valuable resource and essential to 1ife" underlies its acceptance of state regulation of water resources (Boerschinger, 1965, p. 128). 
these conditions. It is shown further that the practice of selling water on a flat rate basis also misallocates resources. Third, improvements in existing water laws and practices are implied and conclusions are drawn which bear importantly on the chapters to follow.

\section{Water Law in the United States}

The Riparian Doctrine

In general, water law in the United States can be divided into two distinct classifications. The eastern states have traditionally adhered to the riparian doctrine of water law. Western states have generally followed the doctrine of appropriation. State water laws are subject to considerable variation and overlap. ${ }^{2}$ In particular, a number of western states have laws incorporating both riparian and appropriative rules (Kazmann, 1965, pp. 201-202).

The common law riparian doctrine holds that the owner of land bordering a stream, river or body of water is entitled to take water for use upon his land (Doyle, 1950, p. 405). The water right is inseparable from the title to the land itself (Davenport and Canales, 1956, p. 283) although, as is also the case with an appropriative right, the riparian right is merely usufructuary as opposed to private ownership of the corpus of the water itself (Hirshleifer et al., 1960,

${ }^{2}$ The discussion of water law in this chapter is limited to brief generalizations about existing laws. Anomalies, which may be found in the laws of individual states, will be ignored except when they are considered to be of particular significance to this study. 
p. 231).

Riparian water users along a stream are said to have coequal rights. The first user of the flow of a stream gains no priority over subsequent users. In theory, the riparian user may utilize the water bordering his land, but must return the water to the stream in view of the rights of downstream landowners. In the extreme, then, there would be no consumptive use of water. Water would be returned to its original course by all users until it flowed into the ocean. Courts have long recognized the great economic waste which results from such a position and have held that each riparian owner has a right to diminish the stream flow as long as the water consumed is put to "reasonable" use. In the event a use is contested, its "reasonableness" is passed upon by the courts. What is considered "reasonable" during periods of normal precipitation may be adjudged "unreasonable" during times of drought. Rights are not lost by non-use and reasonableness may be reevaluated with a change in circumstances (Trelease, 1965, pp. 272-89).

States which hold to the riparian doctrine for surface waters extend it also to ground-water production. The legal principle of "reasonableness" is usually applied to any definite underground stream. which is a source or continuation of a surface watercourse. Percolating water, ground water which is not a part of a definite underground watercourse, is subject to three variations in the basic riparian 
doctrine. ${ }^{3}$

First, some states apply the English common law rule of absolute ownership. An owner of overlying land may make use of percolating waters in any manner which he deems best. He need not consider the effect of his withdrawals on the water supplies of his neighbors.

Second, a number of courts in the eastern United States have extended the principle of "reasonableness" to all ground-water production. A landowner whose water supply is adversely affected by the pumpage of a neighbor may seek remedy in the courts.

The third subdoctrine of riparian law is known as the "correlative rights rule," which developed in the states of California and Utah. This rule requires not only reasonable use, but also adds the requirement that surface owners have equal or proportional rights in the common pool of ground water. Water rights are adjudicated under this rule. Pumpers with records of large "reasonable" use records receive larger quotas relative to those with records of lesser usage (Kirikwood, 1948, pp. 2-4).

The Doctrine of Appropriation

In contrast to the riparian doctrine, the doctrine of appropriation presupposes that the right to use flowing water is a right

${ }^{3}$ The distinction between ground water and surface water is highly unscientific; moreover, the separation of ground water into two types is even less valid. Practically all usable water is meteoric (from precipitation) and seeks a level by moving either over or under the surface (Foley, 1957, pp. 495-96). 
apart from the title to adjacent lands (Davenport and Canales, 1956, p. 283). The appropriative doctrine may be stated simply as "first in time first in right." Water rights may be obtained by a person merely by diverting water to his use. The user need be neither a riparian nor a landowner (Boerschinger, 1965, p. 110). Prior appropriators have preference over later, or "junior," users.

The appropriative doctrine was developed and still prevails in the western United States. In the humid and "water surplus" East most economic demands for water can be satisfied by using the riparian ruie (Hirshleifer et al., 1960, pp. 232-33). In the arid western states it was only natural that a need would be felt to divert water from its normal watercourses to non-riparian land. The appropriative system developed out of this need.

Courts do not normally pass on the "reasonableness" of water use in the states that adhere to the doctrine of appropriation. All that is usually required is that the water appropriated be put to a "beneficial," or non-wasteful use (Breitenstein, 1950, p. 346). A usufructuary right of an absolute nature is granted a prior appropriator which allows him to consume water even at the expense of subsequently sought domestic uses (Gross, 1965, p. 265). Except where statutes provide for regulation by an administrative agency, the use of appropriated water need not be "reasonable" in relation to the rights of others. A senior appropriative right which is put to beneficial use may be taken only through a procedure of condemnation and 
just compensation (Be11, 1965, pp. 382-85). Prior appropriators are protected against junior appropriators and junior users are protected against increased usage by senior users. In time of drought, however, junior appropriators may have their water supplies cut off completely while senior users continue to take their full quotas (Hirshleifer, et al., 1960, p. 236).

Not all of the western states adhere exclusively to the doctrine of appropriation. Some states, California for example, hold both riparian and appropriative doctrines. Only eight of the seventeen western states have explicitly repudiated the riparian rule. ${ }^{4}$ In these eight states the appropriative rule is applied to percolating ground water (Hirshleifer et al., 1960, p. 233).

Interstate Regulation of Water

Interstate water rights have been established either through interstate compacts or by the federal government under the commerce clause of the Constitution. Although interstate compacts have sometimes been entered into, state legislatures are usually reluctant to surrender rights for a period of years except under the most urgent circumstances. In recent years the federal government has increased its control over interstate streams and tributaries of interstate

${ }^{4}$ The eight states which have repudiated the riparian doctrine are Arizona, Colorado, Idaho, Montana, Nevada, New Mexico, Utah and Wyoming. The remaining nine states are California, Kansas, Nebraska, North Dakota, Oklahoma, Oregon, South Dakota, Texas and Washington. 
streams. Originally federal jurisdiction was limited to waters which are navigable in fact. Control has now been expanded to include any river even remotely susceptible of being used in navigation (Forer, 1961, pp. 337-43).

Water Law Trends

In 1957, the legislature of Iowa established a new water rights act. The act decrees that all uses of water must be "beneficial" and prohibits the diversion or taking of water for most uses without a permit from the Water Commissioner (0'Conne11, 1962, p. 551). Permits are given for short periods of time only. Other eastern states are beginning to follow the lead of Iowa by shifting toward administrative control of water resources.

In the West, state ownership and control of water resources--a trend which has arisen only recently in the East--has been accepted for some time. In all of the 17 western states laws have declared water to be the property of the state or its people (Hirshleifer et al., 1960, p. 248).

Transferability of Water Rights

In general, water rights cannot be transferred from one person to another. Riparian doctrine holds that the landowner has the right to use water which borders his land, but this right cannot usually be extended to non-riparian land nor can it be sold. Appropriative law is somewhat more flexible. Appropriated water need not be used on 
riparian land, and some states allow. for transfer from one user to another. Other states, however, do not allow sale or exchange of rights and even prohibit transferring the water from the use for which it was originally appropriated (Hirshleifer et al., 1960, pp. 239-42).

The new trends, toward control of water rights by the federal government or by state administrative bodies, may result in even less flexibility in the private transfer of water rights. The new approach seems to embrace the idea that private ownership of water is something to be avoided. Water should belong to all the people, hence the allocation of water should be accomplished through public agencies. When the need arises public agencies can transfer water from "less important" to "more important" uses.

Summary

The nation's existing water supplies are allocated, for the most part, under two distinct types of state water rules--the riparian and appropriative doctrines. The riparian doctrine limits ownership of water to owners of land contiguous to surface or "underground" watercourses. Under the doctrine of appropriation, water rights are gained by diverting water from a natural watercourse and putting it to "beneficial" use. A riparian right may be lost if the water use is not "reasonable" as interpreted by the courts with domestic use usually receiving top priority. Appropriated water use need not be "reasonable" in the sense that it must be gauged against a hierarchy of priorities, but it must either be used "beneficially," a matter also subject to 
court interpretation in contested cases, or allowed to continue down its original watercourse.

In the main, neither of these doctrines provide firm water rights which may be sold in the marketplace. And the trend is not toward establishing transferrable private rights. On the contrary, more recent water law seems to repudiate private rights in favor of public ownership.

\section{Optimal Allocation of Water}

An optimal allocation of water requires (1) that the values in use $^{5}$ to each user be equated at the margin and (2) that the common marginal value in use be equal to the marginal social cost. This is a specialization of a general theorem of welfare economics which will be taken without proof. ${ }^{6}$ If there is more than one source of water, the resource is optimally allocated when the marginal social costs of all sources of water are equated provided, of course, that

${ }^{5}$ This study follows Hirshleifer et al. (1960, p. 37) in borrowing the term "value in use" from Adam Smith's wealth of Nations (1776, p. 28) to denote the value to society of a givei quantity of water. If social costs or revenues are equal to private costs or revenues, and if perfect competition prevails, marginal value in use may be taken to be the demand price at a given quantity when water is a product, or the value of the marginal product of water when it is an input.

6 For a proof of the general theorem see Samuelson (1958, pp. 229-46), and for the derivation from welfare economics of benefitcost analysis applied to water resource development see Eckstein (1958, pp. 70-75). 
the first condition is satisfied.

Assuming (1) that perfect competition exists in both product and factor markets, (2) that private demand does not differ from social demand for water, and (3) that marginal private costs of water include all social costs, a system of private ownership of rights and market prices will bring about optimal allocation of a community's water resources.

Demand for water is inversely related to its price. Where water is used as a consumable commodity the rational consumer would utilize precisely the quantity of water which equates his marginal value in use with the supply price of water. Additional units of consumption would yield less satisfaction than their cost, thus calling for a reduction in use. Using a smaller than optimal quantity would result in marginal benefits greater than cost at the margin, and this would call for additional consumption.

The factor market would operate similarly. To maximize profits a firm would utilize water to the point where the supply price is equated to the value of the marginal product of water to the firm. Additional units would cost more than the revenue obtained by their application. Using less than the optimal amount would result in marginal revenues exceeding marginal costs prodding the entrepreneur into a greater use of the input.

Any owner of water rights would use water to the point of 
maximum satisfaction or profits, no more and no less. One having rights in excess of his needs would sell his surplus rights. One with a deficiency, or with no rights at all, would buy water rights until the marginal cost of additional rights and his marginal value in use were equated. In a perfect market, the result would be one water price, for any given total usage, which would be equal to the marginal value in use for any user. Users whose marginal values in use exceed the supply price of water and hence the marginal value to other users, would buy additional rights, thus bidding up the price of water rights. Simultaneously, other users would experience a rise in opportunity costs which would exceed their marginal values in use, hence they would sell rights and reduce their water utilization to the point where their marginal values in use would once more equal marginal cost. ${ }^{7}$

Impediments to Market Optimization

Optimum allocation may not be achieved by a system of market prices for several reasons. First, firms purchasing water or producing water under conditions of coristant cost may sell their outputs in markets characterized by imperfect competition, in which case the

$7_{A}$ schematic representation of the marginal value in usemarginal cost equating effect of a perfect market in water rights is presented in Figure 4-6, Chapter IV. 
water resource may be used only up to the point where its marginal revenue product is equal to its marginal cost. Here, water is underutilized as the value of $i$ ts marginal product or the value of the incremental unit to society is greater than its cost. In view of the findings to be presented in the case study of Chapter IV, and in view of the contention that current water pricing policies lead to underpricing and over-building in water (Hirshleifer et al., 1960, pp. 107-13) the imperfect competition overpricing and underutilization problem is worth mentioning.

A second reason why water supplies may not be optimally allocated by private ownership of rights and a market price system is that marginal private costs which are relevant to producer or user decisions do not reflect marginal social costs. This has been well recognized in the literature. ${ }^{8}$ Marginal private costs may understate marginal social costs either because of external diseconomies or because some of the costs associated with increased use are transferred to society. Perhaps the classic example of diseconomies is the case of the common ground-water pool where increased pumpage by one well owner can lower water levels and hence raise marginal pumping costs for other users, while his own marginal pumping cost may remain constant or even fall as a result of the decreasing power costs frequently associated with increased pumpage. In this instance true marginal social costs are

${ }^{8}$ For a discussion and list of references on external effects see Mishan (1964, pp. 98-154). 
not reflected in the costs of the individual whose pumpage increases. The marginal social cost of the production of the increment may only be determined by summing the added costs which are imposed upon all the well owners drawing from the common pool. Another type of external effect, to be demonstrated in Chapter IV, can be created by financing added water supplies or aquifer protection by ad valorem taxes thus transforming a cost which is variable from the standpoint of society into one which is fixed with respect to changes in water usage. When a large water supply project incurs substantial fixed costs and operates with excess capacity, if the price is set at a level high enough to cover average total cost it overstates marginal social cost and water is underutilized. Another possible cause of underutilization, external economies, may cause private costs to overstate social costs; however, this possibility does not seem important in the area of water resources.

Finally, for a private rights-market price system to achieve optimal allocation, the market must be strong and active. A "perfect" market depends on perfect knowledge of prices. In the real world the market in rights will be weak unless adequate knowledge of alternatives is available to prospective traders. Chapter IV discusses a situation where a tradeable ground-water rights system fails to operate efficiently because future prices of a supplementary water source cannot be known with reasonable certainty by prospective sellers or buyers. 


\section{Free Market or Administrative Control?}

A system of private ownership of rights and market prices will optimally allocate water, subject to the exceptions noted above. The question which naturally arises is: Do the exceptions provide sufficient justification for abandoning the idea of private ownership and a private market in water rights? Each exception must be considered separately to provide the answer.

Imperfect competition, to the extent that it does exist in the economy, does pose a problem. A decision in favor of a free market in water rights may or may not be in the direction of economic efficiency if market imperfections exist elsewhere in the economy (Lipsey and Lancaster, 1956-1957, pp. 11-32; McManus, 1959, pp. 209-22; Lipsey and Lancaster, 1959, pp. 225-26; Mishan, 1962, pp. 205-17). It seems reasonable, however, to insist that this need not be taken as an argument against providing a free market in water rights; rather it may be considered an argument against the existence of imperfect competition in the economy. If imperfect competition is to be taken as a parameter which cannot be altered, there are few suggestions for economic welfare which may be offered in the absence of a complete knowledge of the social welfare function. The United States government, however, is committed to the elimination of serious market imperfections, and this analysis is based on the assumption that the government will be reasonably successful in this endeavor. 
External diseconomies, or marginal social costs exceeding marginal private costs, may be eliminated by application of a tax or pumpage charge levied on each unit of production. Either external economies or economies of scale may be handled by subsidizing each unit of production.

Inefficiency created by imperfect knowledge cannot be eliminated by a free market in water rights per se. A procedure for handling a case where imperfect knowledge exists, however, is presented in Chapter IV.

It should be stressed here that nothing in this section militates against a system of firm tradeable private property rights in water. In fact, a strong presumption exists that the best system of water laws would provide for private ownership and unlimited sale and transfer of water rights. If administrative control is warranted because of any of the problems raised above, it can probably rely on tax, subsidy or pricing measures and be applied in conjunction with a private market in rights. Failing this, it can attempt to sinulate the resource allocation effects of the free market by applying appropriate regulation.

\section{An Evaluation of Existing Water Laws}

Existing water laws, it has been noted, do not provide firm water rights. Riparian states usually do not allow for the sale or transfer of water rights. While the law in appropriative doctrine states is somewhat more flexible, it frequently suffers from the same 
defect.

Present water laws frequently operate to misallocate the nation's water resources. Owners of water rights, if not limited in their use of water, will maximize satisfaction (or profits) by using all rights for which marginal gains exceed marginal costs. A riparian rights owner, however, may be forced by the "reasonable use" rule to curtail his use short of the optimal quantity, and the rights of an appropriative rights owner may be insufficient to satisfy current demands. Furthermore, prospective users who fail to gain water rights are left with unsatisfied wants. Water will not be put into its highest valued use under a system which grants rights to some users but does not allow sale to others. Total welfare would normally be enhanced if present rights owners were allowed to sell rights and thus satisfy values in use which at the margin, exceed their own--a situation that is prevented by existing water law.

\section{The Use of Flat Rates}

The use of flat rates for water sold to domestic consumers also poses a problem. Although most domestic water is now metered, flat rates may be found in a few of the largest cjties including New York and Chicago (Hirshleifer et al., 1960, p. 44). Instead of charges which may vary according to the quantity used, a flat monthly connection charge is collected from residential users in these cities. 
An important virtue of the price system is its ability to ration water in such a way that it is put to highly valued uses only. A properly regulated or administered municipal water utility will have a price schedule which equates the marginal cost of water to total demand. At this point total welfare is at a maximum. Greater use would mean that, at the margin, the cost of water to society is greater than the value to society. The use of flat rates has the effect of causing a greater than optimal use. The "extra"-resources required to produce the "surplus" water would be of greater value to society if they were put into other uses. 9

Figure 2-1 illustrates the problem. The demand curve for a municipality is represented by DD'. Marginal costs are MH'. Properly set rates and metering of water will result in the use of quantity $O A$. Since demand may be taken as a measure of marginal utility or marginal value in use, net value in use, or total value in use less total cost, is maximized at that point. Use of flat rates will cause water users to use water to point $D^{\prime}$ where additional use would have zero or negative value. While there is a price being paid for the water under flat-rate pricing, it causes consumers to use water as if the price were zero, for the flat rate will be paid no matter what quantity

${ }^{9}$ Flat rates on water, however, have long been justified with a social revenue argument. It has been held that flat-rate pricing will benefit public health, since it will promote personal cleanliness among the masses (Sleeman, 1955, pp. 231-45). 


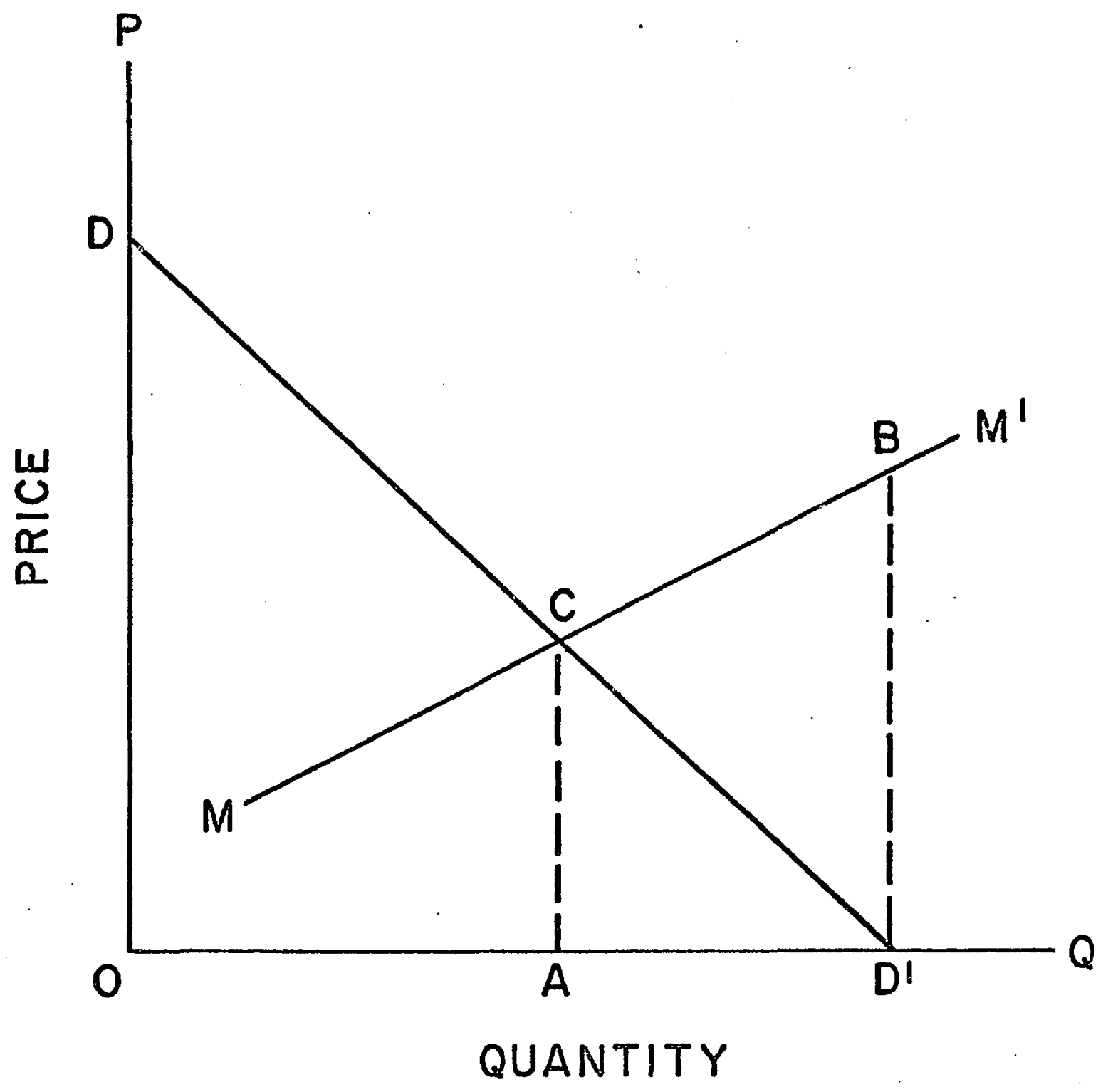

FIGURE 2-1. The Effect of Charging Flat Rates for Water 
is taken. It, therefore, behooves consumers to use all units of water which have positive value to them. This results in an economic loss to society which may be measured by the triangle CBD'.10

\section{Summary of Chapter}

Misconceptions about the nature of water are common. It has been a primary intent of this Chapter to dispel the mistaken notion that water is "something special." Water, it is held, is quite like any other economic good or resource. The decision of whether or not additional supplies of water should be sought depends on the valuation of these additional supplies relative to the value of alternative goods which could instead be obtained with the same amount of sacrifice.

An analysis of water laws makes it clear that water is given a special place among resources. Two doctrines of water law, appropriative and riparian, prevail in the United States. Under these doctrines the right to water is generally treated as an untradeable commodity, though appropriative doctrine does allow for some trading and is probably better suited as a basis for improving water laws (Trelease, 1957, pp. 301-22). The current trend, however, is toward

${ }^{10}$ This assumes, of course, that each potential customer is willing to pay the flat rate, or to put it another way, the area under each individual demand curve must represent a total value in use per unit of time that is greater than the flat price charged for the same period of time. 
more, not less judicial and administrative control of water.

The goal of optimal allocation of water resources can usually be best served by ordaining and maintaining a system of tradeable private water rights. When any of the previously enumerated problems occur they can be corrected by superimposing certain measures, such as charges or subsidies, upon the basic tradeable rights-market price system.

Existing water laws tend to misallocate resources because they do not result in water's being put to its highest valued uses. Further misallocation of present water supplies results from the now diminishing practice of charging flat rates for residential water. The effect of this practice is an over commitment of resources to water production. The indicated correctives would be to begin treating water like any other economic good--making it subject to unconditional ownership, allowing it to be purchased or sold at will, but taking measures to assure that the price of water reflects its marginal social cost.

In the following chapters it will be assumed that the existing legal barriers to economic efficiency can be eliminated. In particular it will be assumed, in Chapter III, that the conmunity as a whole has no legal advantage over individuals in obtaining additional water 
supplies. 11 The analysis of Chapter IV incorporates the assumption that the elimination of existing water quotas in. West and Central Basins of Los Angeles poses no insoluble problem of legality or constitutionality.

${ }^{11}$ The fact that the community does have at least one advantage, the right of eminent domain, only strengthens a major conclusion of Chapter III--that a community project is likely to be chosen over a corporate alternative. Any such legal advantage, however, is excluded from the model which considers cost advantages only. 
CHAPTER III

DECISIONS TO AUGMENT EXISTING SUPPLIES ${ }^{1}$

Water will be efficiently allocated if a sound legal framework and an efficient pricing system have been established. The efficient allocation of existing supplies is a condition necessarily precedent to rational decisions regarding the development of additional water supplies. Otherwise it will not be clear when demand is increasing at a rate that warrants investment in new water-producing facilities. New sources may be prematurely developed under water laws which do not allow trading of rights or under pricing policies which cause overutilization of water.

A community's increasing water demands may prompt it to consider investment in new supplies. Decisions regarding additions to, or replacement of, existing ground-water supplies involve costs that occur over time. On the one hand, a decision to undertake a project supplying water commits the community to an investment of resources not only in the present but also over the life of the project. A decision to take no action, on the other hand, may postpone large expenditures but such a decision is not without costs.

The costs attached to inaction represent increased pumping

1 Much of the material in this chapter has been drawn from two papers (Falk and Stober, 1966; Stober and Falk, 1967, pp. 328-35). Direct references to these writings have been omitted from the text. 
costs as water levels are reduced by pumpage in excess of natural recharge, costs associated with a reduction in water use, costs occasioned by land subsidence, or costs of privately undertaken supply projects. These costs accrue to industry in the form of an increase in the price of water, an input, and to the community in general in the form of lost satisfaction or, in the case of land subsidence, in the form of property damage.

Water is both an input to industry and a commodity to residential consumers. The demand for industrial water is a function of its marginal productivity. A profit-maximizing firm will use water to the point where its cost is equated with its marginal revenue product which, under the assumption of perfect competition, is the value to society of the marginal product. As the demand for a firm's product increases, the demand for water increases ceteris paribus, or, what is equivalent, society places a higher value on a given quantity of industrial water.

Residential demand for water is a function of its price, as well as population, income, and the prices of other commodities. Other things equal, growing incomes and population increase the residential demand for water. Again, this signifies that society places a higher value on any amount of water devoted to residential consumption. The benefits or net returns of a project to provide an additional supply of water are thus the costs that are associated with the failure to take action. Or, to put it another way, the costs of failing to act are the benefits foregone as a result of inaction. 
The increased demands of society call for additional water when the marginal cost of a new supply is less than the marginal value placed on it by the community.

An increase in the community's demand for water may prompt an investigation of available alternatives. The questions which should be answered are: (1) Is inaction the least-cost alternative, and (2) what is the least-cost alternative of developing additional supplies, if additional supplies are clearly warranted? It is the primary objective of this chapter to answer these questions by specifying an economic mode1 for the determination of benefit-cost ratios for a local community. A secondary purpose is to discuss the welfare implications of this model, since it produces different results from one which measures benefit-cost ratios for the nation as a whole.

\section{Criteria for Choice}

\section{Benefit-Cost Ratios}

Water projects have traditionally been evaluated on the basis of benefit-cost ratios where both future benefits and costs are discounted by some "appropriate" interest rate. A project is justified only if the ratio of its benefits to its costs exceeds unity, and among competing projects the one with the highest such ratio is considered "best" (Eckstein, 1958, pp. 47-70). That the benefit-cost ratio of a project should be greater than one is clear. This is merely a requirement that a project should not be undertaken which 
costs more than it is worth. But it does not necessarily follow that projects competing for public funds should be ranked by the ratio and that the order of such ranking should determine budgetary priorities. Errors may result from such an approach.

First, in the selection between mutually exclusive projects, it is net benefits (benefits minus costs) which are important. For example, a project with expected benefits of $\$ 2,000$ and total costs of $\$ 1,000$ has a benefit-cost ratio of 2 , but it would not be preferable to one yielding $\$ 1,500,000$ in estimated benefits at a cost of $\$ 1,000,000$, although the benefit-cost ratio of the second project is only 1.5. To forego an estimated net gain of $\$ 500,000$ in preference to one of only $\$ 1,000$ would be unreasonable. Second, benefit-cost ratios can be ambiguous; benefits expressed net of a portion of costs may produce ratios which differ from those derived by including a 11 benefits and costs. To illustrate, it may be convenient to express the benefits of a project net of a part of the costs, e.g., $\$ 7,000$ less $\$ 600$ in one type of costs yields $\$ 400$ in net benefits. If the basic expenditure is $\$ 200$ a benefit-cost ratio calculated on this basis is 2 . However, if total costs and benefits are included the ratio would be $\$ 1,000 / \$ 800=1.25$. The proper criterion for rating projects would be benefits minus costs, which in this example would be $\$ 200$ whichever way the calculation is made (McKean, 1958, pp. 107-16; Hirshleifer et al., 1960, pp. 137-38). Moreover, subtraction of costs from benefits shows the net gain in present value and if the proper 
costs, benefits and discount rates are used, any project with positive net benefit should be undertaken. In the event this is not possible, i.e., if "capital rationing" is necessary, the problem becomes more complex (Hirshieifer et al., 1960, pp. 169-74); discussion of this aberration, however, will not be covered since it is not pertinent to the problem at hand.

Despite these shortcomings, the benefit-cost ratio will be used as the criterion throughout this study. In the context within which it is used, the benefit-cost ratio will give the same results as the net benefits criterion. The reason is a consequence of the way in which benefits are measured--as the cost of the best alternative course of action. Under this approach only one course of action will yield a benefit-cost ratio in excess of unity, and only that course of action will yield positive net benefits.

\section{Application of Benefit-Cost Ratios}

The measurement of benefits and costs is an extremely difficult problem in appraising the feasibility of a large multiple purpose water project. Total benefits are appropriately measured by the entire areas under the pertinent demand curves for all outputs of the project, including consumers' surplus, and total costs should consider the en- . tire value of the product lost in the private sector due to the diversion of resources to the water project. A simple price times quantity calculation does not correctly measure benefits, and in the case of cost measurement such a calculation will be inadequate if, as a 
consequence of the project, resource prices are changed or if the inputs are bid away from firms operating in imperfectly competitive product markets (Dunn, 1967, pp. 337-42; Stober, Falk, and Ekelund, 1968, pp. 563-68). Moreover, estimation is particularly difficult for benefits which are not marketed, e.g., recreation provided by a reservoir project (Knetsch and Davis, 1966, pp. 125-42). The allocation of the costs of multiple purpose projects to individual purposes is another difficult prablem (Hirshleifer et al., 1960, pp. 93-94). Fortunately, the problems which must be faced in measuring benefits and costs for single purpose projects are far fewer.

This presentation is limited to such a single purpose project, and the approach considers only direct benefits and costs to the 10cality. Diversion of resources to the project is assumed to be minimal. Nevertheless one remaining difficulty, the problem of uncertanty in benefit and cost streams, is ignored entirely in this study. The reason for this omission is that there is, as yet, no completely satisfactory solution for the handling of uncertainty in water resource system design. Although advances are being made in this area and some tools now exist which would be of value in local water project studies (Dorfman, 1966, pp. 129-58), these developments have not been used because they would complicate the analysis to the extent of obscuring several important points.

As noted above, the benefits derived from any community water project may be measured by the costs of the best alternative to the 
action contemplated, since they are the costs avoided by undertaking that project. It is possible, of course, that the best alternative is simply failure to act. The benefits of the action are thus the costs of inaction, or, more precisely, the discounted stream of future costs and benefits foregone as a result of failing to replace or augment the ground-water supply. If the benefit-cost ratio for the best possible action proves to be less than unity, a decision in favor of inaction is optimal.

The choice between any two possible community projects, $A$ and $B$, may be made in the same manner. If the benefit-cost ratio for project $A$ is greater than unity, given the costs of $i$ ts best alternative, $B$, then A should be undertaken. If A's ratio is less than one, its reciprocal, the benefit-cost ratio for $B$, is greater than one and project $B$ should be chosen.

Finally, after selecting the "best" possible community project alternative, the community still has the option of letting private firms undertake their own projects as an alternative to the community project. The benefits for the benefit-cost ratio used in making this decision are the costs associated with the private projects. The costs in the denominator of the ratio are, of course, the costs which would be incurred by the community project. A procedure for measuring and comparing these benefits and costs is presented in the following section. 
The Measurement of the Costs and Benefits of Community Action

The Present Value of Future Costs

Costs that are incurred at different points in time have different values when viewed from the present. To illustrate, let $C_{0}$ be a cost arising at the present time and let $c_{t}$ be a cost arising $t$ years in the future. If $C_{0}$ could be postponed for $t$ years, and the consequent saving invested at the rate of $r \%$ compounded annually, it follows that after $t$ years the original sum $C_{0}$ will have a value of $C_{0}(1+r)^{t}$. Thus to put the $\cos t s C_{0}$ and $C_{t}$ on an equal footing $C_{t}$ must be equal to $c_{0}(1+r)^{t}$. Alternatively, the present value of a cost incurred in year $t$ is defined as

$$
C_{0}=P V C_{t}=\frac{C_{t}}{(1+r)^{t}} .
$$

The present value of a future cost (PVC) may be interpreted as the amount that if set aside now and invested with an annual rate of return of $r \%$ would provide a sum just sufficient to meet the cost when it is incurred.

In general, the present value of a stream of yearly costs, $C_{t}$, is given by the formula

$$
P V C=\sum_{t=1}^{n} P V C_{t}=\sum_{t=1}^{n} \frac{C_{t}}{(1+r)^{t}}
$$


Since cost in year $t$ is discounted for the entire year $t$, as well as for the preceding t- 1 years, this formula treats costs as being incurred on the last day of the year. Thus annual discounting will understate the present value of future costs. ${ }^{2}$

Immediate cash outlays, such as initial costs of construction, should not be discounted. Thus to encompass immediate cash outlays in the general formula it is necessary to sum from zero to $n$, where costs at time zero, $C_{0}$, represent immediate cash outlays. Formula (3-2) then becomes

$$
P V C=\sum_{t=0}^{n} \frac{C_{t}}{(1+r)^{t}}=\sum_{t=0}^{n} c_{t}(1+r)^{-t} .
$$

Now, the present value unit costs for both a non-profit community project and private alternatives can be calculated by an adaptation of the above method. Let $x_{p}$ represent the unknown present value unit cost of water from a community project which is assumed to remain constant over the life of the project, and let $q_{t}$ represent the quantity of water produced in year $t$. Then total cost for the project in year $t$ will be $x_{p} q_{t}$. Similarly, if $x_{c}$ (also assumed to be constant)

In lieu of discrete annual discounting, continuous discounting might have been used, in which case $e^{-r t}$ would replace $(1+r)^{-t}$ as the appropriate discount factor and the definite integral would replace the summation sign. Although continuous discounting is more consistent with the view that output is a continuous flow over the course of the year and that costs are incurred at monthly and weekly intervals, for expository purposes the more familiar discrete discounting method is employed. The difference in the present value of costs is not great and in no way affects the comparisons to be made. 
represents the unknown present value unit water cost of $q^{\prime}{ }_{t}$ units of water in year $t$ for the private alternatives, the alternative cost in year $t$ will be $x_{c} q^{\prime} t$. It follows that for a community project with a life of $n$ years the sum of present value costs will be equal to the sum of quantities produced in each year multiplied by the present value unit cost and discounted by the appropriate factor. Symbolically,

$$
\sum_{t=0}^{n} P V C_{t}=\sum_{t=0}^{n}\left(x_{p} q_{t}\right)(1+i)^{-t}
$$

where $i$ is the rate of discount appropriate to the community project. Since $x_{p}$ is a constant it may be factored out of the summation and upon dividing both sides by the sum of discounted quantities we have

$$
x_{p}=\frac{\sum_{t=0}^{n} P V C_{t}}{\sum_{t=0}^{n} q_{t}(1+i)^{-t}} .
$$

If $k$ is the appropriate discount rate for the private alternatives, the present value unit cost associated with the failure of the community to take action is

$$
x_{c}=\frac{\sum_{t=0}^{n} P V C_{t}}{\sum_{t=0}^{n} q^{\prime}{ }_{t}(1+k)^{-t}} .
$$


It may be helpful to take a somewhat different approach and to view the present value unit cost as an internal price which must be charged for water. When so interpreted, this internal price multiplied by quantities produced in each year generates a revenue stream which, when discounted, is equal to the present value of all costs. Thus this internal price (present value unit cost) is a price just sufficient to cover all costs associated with the project. Moreover, the rate of discount can be interpreted as the rate of return over cost, or simply the net rate of return, on the investment outlay. This latter interpretation may seem rather strained since the discount rate must be selected first and once selected determines (together with the cost and quantity streams) the present value unit cost of water. However, this interpretation does serve to elucidate the fact that the rate of discount must bear some relationship to the net rate of return that a firm expects to realize on alternative investment projects. But to say simply that the discount rate used to calculate present vaiue unit cost must reflect the net rate of return on alternative investment projects is far too vague.

\section{Appropriate Rates of Discount}

The rate of discount for the community project is the cost of capital to the sponsoring body. The cost of capital for the nonprofit conmunity project is simply the interest rate at which the project is financed. The rate of discount to be applied to the private 
alternative, however, presents substantially greater difficulty. If, as will be assumed, the private alternative is an increased cost of water to industrial firms and municipal waterworks, the relevant rate of discount is the corporate cost of capital.

The concept "cost of capital" as applied to a profit-making corporation raises several theoretical issues that have as yet not been satisfactorily resolved (Modigliani and Miller, 1958, pp. 261-97; Durand, 1959, pp. 639-55). While an attempted resolution or even a complete treatment of these issues is beyond the scope of this study, a brief discussion of some of the problems is necessary.

As a starting point, it should be noted that a corporation has a number of alternative sources of funds; it may, for example, retain earnings, utilize depreciation allowances, borrow from financial institutions, issue short- or long-term debt, or issue new shares of either common or preferred stock. Each of these sources has a different objective cost. Since a water replacement project will be longlived only four of these alternative sources of funds need be considered; issuance of new shares, long-term borrowing, issuance of preferred stock, and internal sources (retained earnings and depreciation allowances).

Normally, the cost of equity capital is calculated either as an expected earnings per share/price per share ratio (Dean, 1951, p. 43), or by some variation of a current dividend/price ratio with allowance made for expected dividend growth (Bierman and Smidt, 1960, pp. 147-48). 
The cost of borrowed capital is uniquely dependent on two factors: the effective rate of interest at which the corporation can borrow and the corporate income tax rate. Inasmuch as interest payments are expenses deducted from revenue in arriving at taxable income, the cost of borrowed capital is not the full amount of the effective interest rate, but rather the interest rate reduced by the marginal tax rate multiplied by the interest rate. In short, the cost of debt capital is obtained by multiplying the effective interest rate by one minus the marginal tax rate. The effective rate of interest is readily calculated as the current yield to maturity on the corporation's longtẹrm debt, adjusted, when necessary, for underwriting costs associated with a new debt issue. The cost of obtaining capital by the issue of preferred stock is similarly determined by the current yield on preferred stock.

The cost of capital from internal sources requires more detailed treatment. It might seem at first glance that since internally generated funds require no explicit cash outlay their cost is zero. This, however, is not the case. The alternative to retaining earnings and using these funds to finance an investment project is the payment of dividends. If the financial well-being of shareholders can be taken to be the overriding concern of corporate directorships, then the decision of whether to retain earnings or to pay dividends should hinge on the effect that each of these alternatives has on the net worth of 
the shareholder. Specifically, an investment project financed by internal funds should be undertaken only if it increases the market value of corporate shares by an amount at least as great as the dividend foregone. Since the market evaluates shares on the basis of expected earnings, the increase in the market value of shares will be greater than the investment outlay only if the expected net rate of return on the investment outlay is greater than the ratio of expected earnings to the price of shares, i.e., the cost of equity capital. Thus the cost of equity capital is also the appropriate cost of capital to be applied to internal sources. Moreover, although the argument has been couched in terms of retained earnings, the same argument applies to depreciation allowances. If the use of such funds does not provide a rate of return at least as great as the cost of capital then such funds should not be retained (Cohen and Robbins, 1966, pp. 749-51).

To restate the argument symbolicaliy: let $\mathrm{E}$ represent expected annual earnings; $M$, the total market value of the corporation's shares; then $r$, the cost of capital, will be equal to E/M. In a perfectly functioning capital market, the cost of equity capital may be taken as a constant with respect to a change in expected earnings, because an increase in expected earnings will lead to an increase in the price of shares, as the market discounts the expected increase in earnings. Thus we may write

$$
\Delta M=\frac{\Delta E}{r} .
$$


Let $\Delta I$ represent the increase in investment outlay (foregone dividend) and let $\Delta E^{\prime}$ represent the resulting increase in expected annual earnings on the investment outlay which, for purposes of exposition, is assumed to be a perpetual flow, then

$$
\Delta I=\frac{\Delta E^{\prime}}{i}
$$

where $i$ is the expected rate of return on the investment outlay. Now, it can be seen that if knowledge of the investment project is communicated to the market and the market evaluates earnings expectations in the same way as corporate management $\left(\Delta E=\Delta E^{\prime}\right), \Delta M>\Delta I$, only if $i>r$. In words, the change in the market value of the corporation's outstanding shares is greater than the investment outlay, or foregone dividend, only if the rate of return on investment is greater than the cost of capital.

One is now tempted to conclude that the cost of capital will depend upon the method of finance. If an investment outlay is financed by equity capital or from internal sources one rate would seem applicable, if by long-term debt or preferred stock still other rates seem applicable. Again, this is an unwarranted conclusion. The method of financing an investment project will have an effect, even if only a minor one, on the capital structure. Internal or equity financing will lower the debt/equity ratio and conversely debt financing will raise it. Under the assumption that each corporation has an optimal capital structure that it seeks to achieve and maintain, investment 
outlays must be financed in such a way as to leave the capital structure unaffected. In other words, it is argued that the decision to alter the capital structure is a separate decision. This leads to the conclusion that there is but one cost of capital which must be a weighted average of the cost of equity and senior capital (Donaldson and Pfah 1, 1963, pp. 438-40). Moreover, if one assumes that the corporation has achieved its optimum capital structure, or what it conceives to be its optimum capital structure, the appropriate weights are the current percentages of the corporation's capital provided from debt and equity sources. Thus, al though a particular project may be financed by the issue of debt, for example, maintenance of the desired capital structure will require that other projects be financed by equity capital.

In the preceding paragraphs it was shown that the cost of capital that is applicable as the rate of discount for a long-term investment project is a weighted average of the costs of equity and senior capital. It should be recognized that this conclusion rests on several arbitrary assumptions. First, it was assumed that the overriding objective of the corporation is the maximization of the net worth of $i$ ts shareholders. The second assumption was that shareholders are indifferent between an equal increase in dividends and in the market value of shares; an assumption which because of differential tax rates on income and capital gains is not likely to be realized (Gordon, 1962, p. 131). Third, it was assumed that there exists 
an optimum capital structure for any corporation which the corporation achieves and seeks to maintain. Even if these assumptions are accepted, the cost of equity capital depends upon expectations with respect to earnings. Thus a cost of capital can only be calculated by making arbitrary assumptions with regard to earnings or dividend expectations. Consequently, there emerges no uniquely determined single rate that may be taken to represent the "true" cost of capital.

One way out of this dilemma is to make the necessary assumptions regarding expected earnings, calculate the expected earnings/price ratio, determine the cost of debt capital, apply the appropriate weights, and call the resulting figure the cost of capital. Another alternative is to compute a range of rates, representing a confidence interval, so to speak, for the "true" cost of capital. Both approaches can be combined advantageously; first a point estimate is made of the cost of capital based upon the trend of earnings and earnings/price ratios in the recent past. Second, tests are made of the sensitivity of present value unit costs of water to a range of discount rates. The "cut-off point" that the corporation employs in deciding whether or not to undertake an investment project will serve as an upper bound for this range, since this is the rate below which, risk considered, the corporation feels that a given investment would be detrimental. The cut-off rate of return may be regarded as the corporation's own implicit estimate of its cost of capital, perhaps inflated by a risk premium. The current yield to maturity on the 
corporation's long-term debt reduced by the corporate income tax rate, i.e., the cost of $i$ ts debt capital, may be taken as the lower bound. This use of a broad range of rates to represent the cost of capital has a distinct disadvantage, both in comparing alternative projects within the same corporation and for benefit-cost analyses of community projects having as benefits the discounted costs of the best private corporate alternative. First, for two alternative company projects, one involving high construction costs but low operating and maintenance costs, and the other involving a smaller initial expense but higher costs in subsequent years it is quite possible that discounting by the highest rate will yield the lowest present value unit cost for the second project, whereas discounting by the lowest rate may reverse the ranking. In such cases, the economist may take some comfort in the fact that ultimately the decision between the two projects must be made by corporate management. Moreover, in deciding between the two projects corporate management not only provides the economist with what it considers to be the best alternative, but also narrows the range within which it regards its appropriate cost of capital to lie. In the absence of a decision by management, the economist is justified in placing more confidence in rates of discount lying closer to the upper than to the lower bound.

If the single rate representing the cost of capital for the community project results in a net community cost per unit (to be defined later) that lies outside the range of present value unit costs 
calculated for the corporate project, the resultant benefit-cost ratio is unambiguous; it is either greater than one, favoring selection of the community project, or less than unity, prompting rejection. If the net community cost per unit lies between these limits, a problem does indeed exist, for the benefit-cost ratio would be shown as both greater than one and less than one, depending on which company discount rate is used. No a priori rule can be offered for resolving this problem; if such a problem arises it can be resolved only by a careful examination of the circumstances peculiar to that particular case. The analys is contained in the following sections strongly suggests, however, that this problem is not likely to be encountered in practice.

\section{Present Value Unit Cost: Community Project}

The total cost $\left(C_{t}\right)$ associated with a water project in any year $t$ may be divided into three categories: construction $\cos t\left(K_{t}\right)$, cost of operation and administration $\left(A_{t}\right)$, and maintenance cost $\left(M_{t}\right)$. In addition there may be some cost offsets such as salvage value $\left(s_{t}\right)$ either of facilities made unnecessary by the project or, more commonly, of the assets of the project itself at the end of its useful life. Only the latter type of salvage value will be considered in the calcu-. lations of this study; however, the reader will recognize that other offsets could be acconmodated in the basic model. Total cost in any year $t$ is obtained by summing the three types of cost and deducting cost offsets. Symbolically, 


$$
C_{t}=K_{t}+A_{t}+M_{t}-S_{t}
$$

The present value of all costs of the community project is obtained by discounting cost in each year by the cost of capital and summing over the life of the project. Present value unit cost is then obtained by dividing through by the sum of discounted quantities. Thus discounting (3-9) by the cost of capital, summing to obtain the present value of costs and substituting the result into (3-5) gives (Hirshleifer et al., 1960, p. 276)

$$
x_{p}=\frac{\sum_{t=0}^{n}\left(K_{t}+A_{t}+M_{t}-S_{t}\right)(i+i)^{-t}}{\sum_{t=0}^{n} a_{t}(i+i)^{-t}} .
$$

\section{Present Value Unit Cost: Corporate Alternative}

Computation of the present value cost for a private undertaking is, however, not so straightforward. A cost incurred by a profit-making corporation reduces revenue by an amount equal to the cost, but, and this is the important point, it also reduces the corporate income tax liability. Thus the relevant cost figure for the corporation is not the full amount of the cost, but only that part of the cost that reduces after tax revenue, which shall be referred to as the net cash outlay resulting from the cost. For operation cost $\left(A^{\prime}{ }_{t}\right)$ and maintenance $\cos t\left(M^{\prime}{ }_{t}\right)$ the reduction in after tax income in 
year $t$ will be $A^{\prime}{ }_{t}+M^{\prime}{ }_{t}-T_{t}\left(A^{\prime}{ }_{t}+M^{\prime}{ }_{t}\right)$ which is equal to $\left(1-T_{t}\right)\left(A_{t}{ }_{t}+M^{\prime}{ }_{t}\right)$, where $T_{t}$ represents the marginal corporate income tax rate in year t. But, assuming that the estimated salvage value at the beginning of the project life is realized exactly by sale of assets at the end of the project life, salvage value $\left(S^{\prime}{ }_{t}\right)$ will enter into the calculation unaltered, since it will have no effect on taxable income.

Construction costs $\left(K^{\prime}{ }_{t}\right)$ are treated differently. In that such costs must be capitalized and then depreciated over the life of the asset, it is appropriate to include the full amounts of construction costs in the year, or years, in which they are incurred. In subsequent years an allowance for depreciation $\left(D_{t}\right)$ occasions a cost offset. Since the allowance for depreciation permits the company to write down its taxable income by an equivalent amount, the resulting reduction in the tax liability is $\left(T_{t}\right)\left(D_{t}\right)$. Combining the results of this and the preceding paragraph, the net cash outflow in year $t$ is then

$$
C^{\prime}{ }_{t}=K^{\prime}{ }_{t}+\left(1-T_{t}\right)\left(A^{\prime}{ }_{t}+M^{\prime}{ }_{t}\right)-S^{\prime}{ }_{t}-\left(T_{t}\right)\left(D_{t}\right) .
$$

Present value unit cost of water for the company project is now obtained in the same manner as for the community project; discounting (3-11) by the cost of capital and summing to obtain present value cost 
and then substituting the result into (3-6) to obtain 3

$$
x_{c}=\frac{\sum_{t=0}^{n}\left[K^{\prime}{ }_{t}+\left(1-T_{t}\right)\left(A^{\prime}{ }_{t}+M^{\prime}{ }_{t}\right)-S^{\prime}{ }_{t}-\left(T_{t}\right)\left(D_{t}\right)\right]\left[(1+k)^{-t}\right]}{\sum_{t=0}^{n} q_{t}^{\prime}(1+k)^{-t}}
$$

For purposes of comparison the initial assumption is made that private water users will be forced to take action and that the action will involve a cost stream identical in timing to that of the community alternative. In deriving a benefit-cost ratio for a community project two additional assumptions will be made: first, that the management of the community project is neither more nor less efficient than the managements of the best corporate a]ternatives; and second, that there are constant returns to outlay in the production of water. The first assumption requires no comment. The second is necessitated by the fact that the community project, supplying water to a group of water users, will be larger than any single corporate project. Under

\section{${ }^{3}$ The currently effective $7 \%$ federal investment tax credit is} omitted from the analysis of this chapter. The credit has been used by the government both as an incentive to investment and as a countercyclical tool since its introduction by the Revenue Act of 1964 (Cook, 1967, pp. 227-33). In 1966 it was suspended as an inflation combatting measure; originally the suspension period was to run from October 10, 1966, through December 31, 1967 (P.L. 89-800), but it was reinstated earlier than planned, on March 9, 1967 (P.L. 90-26). Since the credit is a direct offset to taxes, it can be taken as a deduction in costs during the year of construction. This can be accomplished easily by replacing $K_{t}$ in expression (3-12) by $0.93 K_{t}$. No other changes need be made; the credit does not affect the depreciation basis. 
the assumption of constant returns to outlay, corporate projects may be viewed in one of two ways. First, they may be thought of as one large corporate project composed of a number of individual projects providing, in total, the same quantity of water as the community project and hence having the same costs. Alternatively, the corporate project may be viewed as the project of only one water user, but being identical to the community project reduced by an appropriate scale factor. If the second view is adopted then, al though each cost for the corporate project will be smaller, the output will be reduced proportionately. Thus in either case, the primes in formula (3-12) can be eliminated. If we make the further initial assumption that the cost of capital is the same for the community as for the corporate project $(i=k)$, then formula (3-12) becomes

$$
x_{c}=\frac{\sum_{t=0}^{n}\left[K_{t}+\left(1-T_{t}\right)\left(A_{t}+M_{t}\right)-S_{t}-\left(T_{t}\right)\left(D_{t}\right)\right]\left[(1+i)^{-t}\right]}{\sum_{t=0}^{n} q_{t}(1+i)^{-t}} .
$$

Formula (3-13) would be the numerator of a community project benefit-cost ratio expressed in unit costs and benefits, given identical corporate project and community project costs--including costs of capital. However, formula (3-10) for $x_{p}$, project unit cost, is not the full expression required for the denominator of the benefit-cost calculation. For this we must calculate the "net community cost per 
unit.." If companies purchased water from the community in lieu of providing their own water supplies they would have to pay the community $x_{p}$ to cover all the project costs including interest. But if the marginal tax rate is constant over time, the net community cost per unit would be only $(1-T) x_{p}$, since the purchases are expenses deductible from gross income for tax purposes. Hence both sides of formula (3-10) are multiplied by $(1-T)$ to form the denominator, and noting that the discounted quantity streams cancel out the benefit-cost ratio becomes

$\frac{x_{c}}{(1-T) x_{p}}=\frac{\sum_{t=0}^{n}\left(K_{t}+A_{t}+M_{t}-S_{t}\right)(1+i)^{-t}-T \sum_{t=0}^{n}\left(A_{t}+M_{t}+D_{t}\right)(1+i)^{-t}}{(1-T) \sum_{t=0}^{n}\left(K_{t}+A_{t}+M_{t}-S_{t}\right)(1+i)^{-t}}$, and assuming construction costs to be incurred at time zero

$\frac{x_{c}}{(1-T) x_{p}}=\frac{1}{(1-T)}\left\{1-T\left[\frac{\sum_{t=0}^{n}\left(A_{t}+M_{t}\right)(1+i)^{-t}+\sum_{t=0}^{n} D_{t}(1+i)^{-t}}{\sum_{t=0}^{n}\left(A_{t}+M_{t}\right)(1+i)^{-t}+k_{0}-S_{t}(1+i)^{-t}}\right]\right\}$

Now, it is clear that $\sum_{t=0}^{n} D_{t}=k_{0}-S_{n}=k_{0}-S_{t}$, i.e., the total depreciation allowed over time is equal to the initial capital outlay in year 0 less the salvage value in the final year $n$. With a 
positive rate of discount, however,

$$
K_{0}-S_{t}(1+i)^{-t}>\sum_{t=0}^{n} D_{t}(1+i)^{-t}
$$

since $D_{t}$ is discounted and net of $S_{t}$. It follows, then, that the expression within the square bracket of (3-15) is less than one, and thus the benefit-cost ratio would be greater than one even, as is unlikely, if the corporate cost of capital is as low as the community borrowing rate.

To repeat, the benefit-cost ratio must always be greater than one when returns to scale are constant and when the costs of the two projects are discounted by the same interest rate. The absolute magnitude of the ratio will depend upon the tax rate, the life of the project, the timing of capital outlays, the method of depreciation, and the rate of discount. As the marginal tax rate is increased, the denominator of (3-14), hence (3-15), is reduced by the full amount of the tax and the numerator by only a fraction of the tax. Thus the benefit-cost ratio is raised. An increase in the present value of the depreciation allowance relative to the present value of construction costs will lower the benefit-cost ratio. This may occur in one of three ways: the allowance, for tax purposes, of a more rapid writeoff; ${ }^{4}$ a reduction in the length of the project's life; or,

${ }^{4}$ In the extreme case if the company were allowed to write off the entire investment at the time it occurred, and if $S_{t}=0$ for all $t$, 
given the project's life span, a postponement of capital outlays. Finally, an increase in the rate of discount by placing a heavier premium on present, as opposed to future, costs reduces the present value of depreciation relative to that of capital outlays and hence increases the benefit-cost ratio.

The conclusions expressed in (3-15) can be rephrased in terms of relative unit costs. Multiplying both sides of (3-15) by $(1-T) x_{p}$, the unit cost of the corporate project is seen to be less than the price which the community must charge to cover its costs. The important point, however, is that the unit cost of the corporate project is greater than the net cash outlay resulting from the purchase of a unit of water from the community project at a price $x_{p}$. Corporate water users, therefore, realize a cost saving by purchasing from the conmunity project.

Recall that the i's in the numerator in the square bracketed expression of the right hand term of equation (3-15) represent the corporate cost of capital, while the i's in the denominator of the same expression represent the community cost of capital. Note, therefore, that an increase in the corporate cost of capital relative to the

$$
\sum_{t=0}^{n} D_{t}(1+i)^{-t}=k_{0},
$$

and the square bracketed expression in (3-15) would equal unity as would the benefit-cost ratio. 
community cost of capital reduces the numerator of the square bracketed fraction relative to the denominator and thus raises the benefit-cost ratio.

Finally, it should be observed that the currently authorized investment tax credit, allowing the company a tax offset of 7 percent of certain depreciable investments, tends to lower the benefit-cost ratio. Calculations show, however, that a much larger credit would be required to invalidate the general conclusion that the benefitcost ratio of equation (3-15) will be greater than unity. 5

Economies of scale in the production of water strengthen the conclusion that the community benefit-cost ratio must exceed unity. If, on the other hand, diseconomies of scale are important, then the preceding analysis has overstated the advantage of the community project. However, it is shown (Figure 3-1, p. 77) that diseconomies of scale must indeed be substantial before the basic conclusion is overturned.

The community project's cost of capital will almost inevitably be lower than the cost of capital to the corporate project. If the community project is an arm of a state or municipal government, this will mean that the community project will be enabled to issue tax

${ }^{5}$ An example is given in the following section showing the effect of the present investment tax credit on a benefit-cost ratio for a hypothetical case which incorporates the constant returns to outlay asșumption. 
exempt bonds, and hence in most circumstances be able to borrow at a lower rate than the corporation. In short, the federal and state corporate income taxes combined with a lower cost of capital for a community project provide a cost advantage to the community project, which can be offset only by strong diseconomies of scale in the production of water.

\section{Community Project Benefit-Cost} Ratios: An Example

A general method was developed for calculating benefit-cost ratios for alternative water replacement projects. It now remains to provide an application of this method to illustrate the significance of the conclusions.

Again assume constant returns to outlay; the corporate project may then be viewed as an agglomeration of company projects having total cost and water output streams identical to those of the community project. Further assume that either project must replace a portion of the groundwater supply (100,000 acre-feet per year) at a given point in time (time zero); and that the demand for water will remain constant at this level over the life of the project. Construction costs for the project, or group of projects, are treated as being incurred at time zero. The total of such costs is $\$ 10$ million. Facilities are sold for a net salvage return of $\$ 100,000$ at the end of year 30 (the project's terminal date). Operating costs are assumed 
to be directly related to output, and, at $\$ 5.50$ per acre-foot, are $\$ 550,000$ per year. Maintenance costs are treated as a constant annual percentage $(2 \%$ ) of construction costs and thus total $\$ 200,000$ a year.

The Non-Profit Community Project Unit Costs

Calculation of the present value unit water cost of the community project is now straightforward. Using the data from the preceding paragraph, formula (3-10) becomes

$x_{p}=\frac{10,000,000+\sum_{t=1}^{30}(550,000+200,000)(1+i)^{-t}-100,000(1+i)^{-30}}{\sum_{t=1}^{30} 100,000(1+i)^{-t}}$

which reduces to

$$
x_{p}=\frac{10,000,000+750,000 \frac{(1+i)^{30}-1}{i(1+i)^{30}}-100,000(1+i)^{-30}}{100,000 \frac{(1+i)^{30}-1}{i(1+i)^{30}}}
$$

where $x_{p}$ represents the cost per acre-foot. Table 3-1 provides unit costs for rates of discount (costs of capital) of $4,6,8$, and $10 \%$. An increase in the cost of capital from 4 to $6 \%$ raises unit costs by $\$ 1.48$ per acre-foot while an increase in the cost of capital from 4 to $10 \%$ raises the cost per acre-foot by $\$ 4.83$. The average annual cost rises by $\$ 483,000$ as the cost of capital is increased from 4 to $10 \%$. 
TABLE 3-1. Community Project: Water Costs at Selected Rates of Discount

\begin{tabular}{ccc}
\hline $\begin{array}{c}\text { Discount } \\
\text { Rate }\end{array}$ & $\begin{array}{c}\text { Present Value } \\
\text { Unit Water Cost } \\
\text { Per Acre-Foot }\end{array}$ & $\begin{array}{c}\text { Average Annual } \\
\text { Cost }\end{array}$ \\
\hline 0.04 & $\$ 13.27$ & $\$ 1,327,000$ \\
0.06 & 14.75 & $1,475,000$ \\
0.08 & 16.37 & $1,637,000$ \\
0.10 & 18.10 & $1,810,000$ \\
\hline
\end{tabular}

Corporate Project Unit Costs

Computation of units costs for the corporate project are complicated by the corporate tax structure. For a corporation operating in Louisiana and having an annual income in excess of $\$ 25,000$, the marginal federal income tax rate of $48 \%$, ignoring the temporary $10 \%$ surcharge, and the Louisiana state corporation income tax of $4 \%$ are applicable. Calculation of the net tax is complicated by the fact that each level of government allows the deduction of the tax actually paid to the other in arriving at taxable income. To calculate the net tax rate, $T$, applicable to a one dollar increment in income, let $F$ represent the nominal federal rate and $S$, the nominal state income tax rate, while $T_{f}$ and $T_{s}$ are the applicable net rates for the federal 
and state governments respectively. Now

$$
T_{S}=S\left(1-T_{f}\right)
$$

and

$$
T_{f}=F\left(1-T_{s}\right) .
$$

Substitution of $(3-20)$ into $(3-19)$ and $(3-19)$ into $(3-20)$ gives the results

$$
T_{S}=\frac{S-F S}{1-F S}
$$

and

$$
T_{f}=\frac{F-F S}{1-F S}
$$

which upon adding yields

$$
T=T_{S}+T_{f}=\frac{F+S-2 F S}{1-F S} \text {. }
$$

Using (3-23) the net marginal corporate income tax rate $T$ for Louisiana corporations is calculated to be $49.1 \%$. The rate is assumed to remain constant over the life of the project. Again, no allowance is made for an investment tax credit.

Calculation of depreciation is complicated by the existence of more than one allowable method. If it could be assumed that each participating company employed the "strajght line" method of depreciation, then annual depreciation would be simply 1/30th of construction costs less salvage value. This assumption, however, lacks realism. A more realistic first approximation is to assume that each company uses sum of the years-digits depreciation. This method yields the greatest 
present value of the depreciation allowance for projects having the characteristics assumed above, and given any reasonable range for corporate cost of capital (Davidson and Drake, 1961, pp. 442-52; Hall and Jorgenson, 1967, pp. 399-400). Sum of the years-digits depreciation, therefore, minimizes the present value unit cost for the corporate project.

Table 3-2 presents computations of unit costs for the corporate project. The figures were obtained by substituting the data of this section into formula (3-12). As in the case of the community project, it is seen that unit costs are highly sensitive to variations in the discount rate. The average annual cost of water ranges from $\$ 766,000$ when costs and outputs are discounted at $4 \%$ to $\$ 1,214,000$ when discounted at $10 \%$.

TABLE 3-2. Corporate Project: Water Costs at Selected Rates of Discount

\begin{tabular}{lcc}
\hline $\begin{array}{c}\text { Discount } \\
\text { Rate }\end{array}$ & $\begin{array}{c}\text { Present Value } \\
\text { Unit Water Cost } \\
\text { Per Acre-Foot }\end{array}$ & $\begin{array}{c}\text { Average } \\
\text { Annua1 } \\
\text { Cost }\end{array}$ \\
\hline 0.04 & $\$ 7.66$ & $\$ 766,000$ \\
0.06 & 9.02 & 902,000 \\
0.08 & 10.51 & $1,051,000$ \\
0.10 & 12.14 & $1,214,000$ \\
\hline
\end{tabular}




\section{A Comparison of Costs}

Comparison of Tables $3-1$ and $3-2$ reveals that the corporate project can apparently produce water at a lower unit cost than the community project. In fact, even if the cost of capital were $10 \%$ for the corporate project and only $4 \%$ for the community project, the unit cost of water would appear to be less for the company project. As shown in the first section of this paper, this conclusion is a result of the tax structure.

The relevant comparison, however, is not between the apparent unit water cost of the corporate and community projects, but between the cost to the company of purchasing water from the community project and the cost of supplying its own needs. It will be recalled that the company's cost of purchasing water from the community project is equal to one minus the corporate tax rate multiplied by the price which the community project charges. Thus the comparison made in Table 3-3 is between the effective cost to the company (50.9\% of the unit cost of the community project) and the company's own cost. It is to be noted that the corporation's cost of purchasing water is lower than its cost of producing water at every rate of discount. Moreover, the difference between the costs of the two alternatives increases as the rate of dis: count rises--ranging from a low of $\$ 0.87$ per acre-foot at $4 \%$ to a high of $\$ 2.84$ at $10 \%$. This in turn means that if both projects had a $4 \%$ cost of capital, the corporation would save $11.9 \%$ of the total cost by 
purchasing from the conmunity project; if the costs of capital were both $10 \%$ the cost saving would be $24.1 \%$.

TABLE 3-3. Corporation Cost of Water: Comparison between Producing Its Own Supply and Purchasing from the Community Project at Selected Rates of Discount

\begin{tabular}{|c|c|c|c|c|}
\hline \multirow[b]{2}{*}{$\begin{array}{l}\text { Discount } \\
\text { Rate }\end{array}$} & \multicolumn{3}{|c|}{$\begin{array}{c}\text { Dollar Cost of One Acre-Foot } \\
\text { of Water to the Corporation } \\
\end{array}$} & \multirow[b]{2}{*}{$\begin{array}{l}\text { Percentage } \\
\text { Difference }\end{array}$} \\
\hline & $\begin{array}{l}\text { Producing } \\
\text { Own } \\
\text { Supply }\end{array}$ & $\begin{array}{l}\text { Purchasing from } \\
\text { Community } \\
\text { Project }\end{array}$ & Difference & \\
\hline 0.04 & $\$ 7.66$ & $\$ 6.75$ & $\$ 0.91$ & 11.9 \\
\hline 0.06 & 9.02 & 7.51 & 1.51 & 16.7 \\
\hline 0.08 & 10.51 & 8.33 & 2.18 & 20.7 \\
\hline 0.10 & 12.14 & 9.21 & 2.93 & 24.7 \\
\hline
\end{tabular}

The effect of different rates of discount, or costs of capital, on the saving that the corporation realizes by purchasing from the community project rather than by supplying its own needs is shown in Table 3-4. It will be recalled that if the community project is an arm of a state or municipal government and can issue tax exempt revenue bonds, the cost of capital to the community project will be lower than that of the corporate project. Thus the more relevant entries in 
Table 3-4 are those below the principal diagonal. An effective interest rate of less than $6 \%$ is normal for a state or municipally sponsored project, ${ }^{6}$ in which case columns 1 and 2 of Table 3-4 are relevant for unit cost comparisons; showing the cost saving per million gallons for selected corporate costs of capital. If the cost of capital to the corporation is $8 \%$, for example, and the community interest rate is $4 \%$, the corporation would realize a saving of $\$ 3.76$ per acre-foot by purchasing water from the community project rather than by producing its own replacement supply. If the community were forced to pay a $6 \%$ interest rate, and the corporate cost of capital remained at $8 \%$ the advantage would be reduced to $\$ 3.00$ per acre-foot.

TABLE 3-4. Corporation's Savings, in Dollars per Acre-Foot, Resulting from the Purchase of Water from the Community Project at Different Rates of Discount

\begin{tabular}{lcccc}
\hline \multirow{2}{*}{$\begin{array}{c}\text { Corporate Cost } \\
\text { of Capital }\end{array}$} & \multicolumn{4}{c}{ Community Cost of Capital } \\
\cline { 2 - 5 } & 0.04 & 0.06 & 0.08 & 0.10 \\
\hline 0.04 & 0.91 & 0.15 & -0.67 & -1.55 \\
0.06 & 2.27 & 1.51 & 0.69 & -0.18 \\
0.08 & 3.76 & 3.00 & 2.18 & 1.30 \\
0.10 & 5.39 & 4.63 & 3.81 & 2.93 \\
\hline
\end{tabular}

${ }^{6}$ At this time, municipal bond yields are about $5.25 \%$ and appear to be rising (Wall Street Journal, March 17, 1969). 
The basic conclusion that it is less expensive for the corporation to purchase water from the community project rather than to supply its own needs is incorrect only if the cost of capital is substantially lower to the corporation than to the community project. Table 3-4 shows that only if the cost of capital to the community project is over $6 \%$ will a $4 \%$ cost of capital to the corporation make the corporation's cost of producing water lower than the effective cost of purchasing water from the community project. Alternatively, with a $6 \%$ corporation cost of capital, the cost of capital to the community project must be over $8 \%$ to make the corporate project feasible. These cases are indeed unlikely, and it may be concluded that such differences in the costs of capital as are likely to exist will increase rather than diminish the comparative advantage of the community project.

\section{Benefit-Cost Ratios}

Figure 3-1 shows benefit-cost ratios for al1 community and corporation costs of capital from $0 \%$ to $10 \%$. The assumption of constant returns to outlay has been retained. The shaded area encompasses all reasonable discount rates--2\% to $7 \%$ for the community project, and $6 \%$ to $9 \%$ for the corporate project. Every possible combination within this area has a benefit-cost ratio greater than unity. Again, the analysis shows a strong bias in favor of the community project. If the community project cost of capital were $5 \%$, for example, and the corporate cost of capital were $7 \%$ the resulting benefit-cost ratio is 


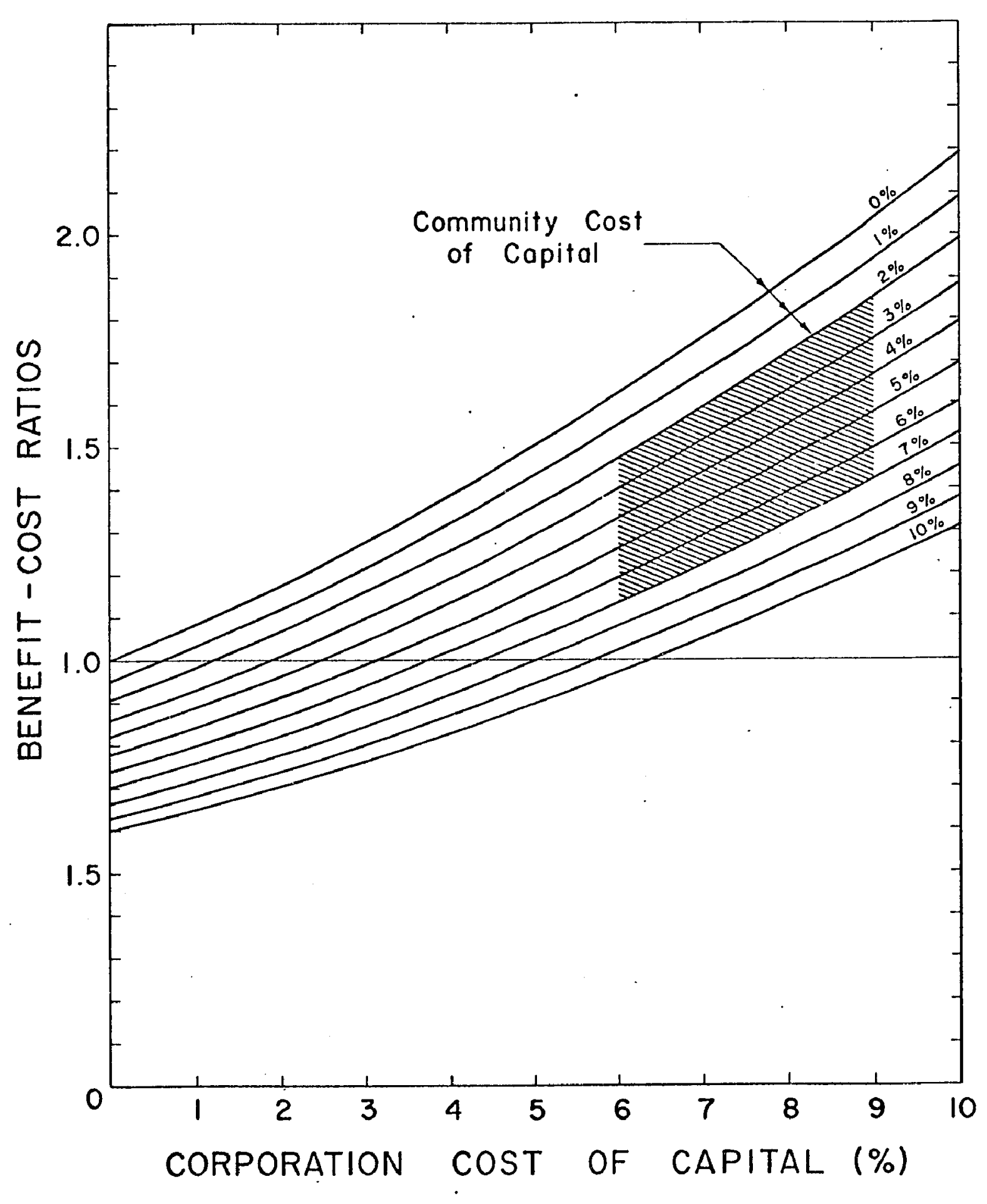

FIGURE 3-1. Community Project Benefit-Cost Ratios Assuming Constant Returns to Outlay 
1.36. Under these conditions $\$ 1.36$ in present value benefits would be returned to the community for each $\$ 1$ in present value costs; building the community project would be most desirable.

Should the federal government's $7 \%$ investment tax credit be included in the computations, benefit-cost ratios would be lowered slightly. With a $7 \%$ corporate cost of capital the corporation unit cost would fall from $\$ 9.64$ to $\$ 9.08$, and again taking the community cost of capital to be $5 \%$ the benefit-cost ratio would be reduced from 1.36 to 1.28 .

It has been noted that economies of scale, or increasing returns to outlay, strengthen the comparative advantage of the community project. The possibility of diseconomies of scale bears some examination. How strong must diseconomies of scale be in order to overturn the basic conclusion? For some idea of the magnitude of diseconomies required let us suppose that the corporate project again has the $\$ 10$ million initial construction cost, $\$ 750,000$ per year operation and maintenance costs, and $\$ 100,000$ salvage value. But let us now assume that the community project costs $\$ 13$ million, that operating costs remain at $\$ 5.50$ per acre-foot or $\$ 550,000$, and that maintenance costs remain at $2 \%$ of construction costs or $\$ 260,000$ per year. Again assume that project life in either case is 30 years and salvage value at the end of year 30 is $\$ 100,000$. A benefit-cost ratio of unity is computed if the community project and corporate alternative discount rates are both taken to be $5.8 \%$. A corporate project involving a capital outlay 
of $\$ 10$ million is precisely as costly from the community standpoint as a community project having a $\$ 13$ million capital outlay. Using the more realistic discount rates of $7 \%$ and $5 \%$ for the corporate and community projects respectively would call for selection of the community project even if its capital outlay totalled $\$ 15$ million and maintenance costs were increased proportionately, for the benefit-cost ratio in this instance would be 1.08. It is clear, then, that diseconomies of scale must indeed be substantial to overturn the basic conclusion that federal and state corporate income tax combined with a lower conmunity cost of capital provide a distinct cost advantage to the community project.

\section{Public Investment Criteria and National Economic Welfare}

The literature on public investment optimization has been concerned only with the effect of public capital expenditures on national welfare. The principal concern has been with federal level expenditures while investment by state and local government has received scant consideration. The tools which have been developed to analyze federal expenditures remain generally applicable, but the local problem has been shown, in the preceding sections, to be sufficiently different to require modification. It appears that this situation would be at least a little disquieting to welfare economists. But the question which was to be answered was: how should a local community choose between alternative water projects? Existing institutions form 
the framework within which the answer must be formulated. Only the viewpoint of the locality has been given consideration, but it is evident that the community project is not optimal from the national we 1fare standpoint if it requires a commitment of resources considerably in excess of the corporate alternative.

In an example in the preceding section a $\$ 15$ million community project was found to be preferable, from the community viewpoint, to a $\$ 10$ million corporate alternative. There is no doubt that the national benefit-cost ratio would be less than unity, but how much less hinges on the appropriate discount rate which would be used to discount the costs of both the community and corporate projects. The social discount rate, however, has been the center of much controversy.

If both the community and private projects involve the same commitment of resources, at every point in time, the benefit-cost ratio reflecting national welfare is unity. The ratio would be less than unity if a community project were selected over a corporate project requiring a smaller sacrifice of resources. Thus, the community decision rule may well lead to an inefficient allocation of resources.

The Appropriate Social Discount Rate

The social rate of discount is a crucial factor in the selection among alternatives from the viewpoint of the nation as a whole. Normally, the heaviest costs associated with a water project are ex- 
perienced early in the project life. These are the initial capital costs. When the greatest costs occur in the first few years and benefits are produced in later years, a high discount rate will tend to lower the benefit-cost ratio. The project will be rejected if the rate is sufficiently high. Lower discount rates may yield benefitcost ratios greater than unity and lead to acceptance.

Selection of the proper discount rate is much more crucial in choosing among alternative projects when the cost streams are dissimilar over time. A rate which is either "too low" or "too high" will produce an erroneous benefit-cost ratio which may result in an improper decision. Benefit-cost ratios may vary directly or inversely with changes in the discount rate. If the time shapes of the cost streams differ the relationship may be an inverse one. To illustrate both cases by contrived examples take first a case where benefits are $\$ 100,000$ per year for ten years and total costs are capital costs of $\$ 7.36$ million incurred at the beginning of the project life. At a $6 \%$ discount rate the benefit-cost ratio is unity. Any higher rate will produce a ratio less than one making the project unacceptable from a national welfare standpoint. Any lower rate will call for acceptance. This is probably the typical situation for water resource projects. Now, however, take the problem of deciding between two alternative projects. The benefit stream--the cost of project A--is composed of an initial outlay of $\$ 9$ million and subsequent costs of $\$ 3.3$ 
million per year for 3 years. The cost stream for alternative $B$ has an initial outlay of $\$ 10$ million and subsequent outlays of $\$ 1$ million, $\$ 3$ million and $\$ 5$ million in years 1,2 and 3 respectively. A social rate of discount of $7 \%$ will produce a benefit-cost ratio of unity, but a higher discount rate produces a benefit-cost ratio greater than one while a lower rate yields a ratio which is less than one. The decision procedure is reversed. A high discount rate calls for acceptance; a low rate calls for rejection. Although this may not represent the usual case, it would apply to selection among some multi-stage water project alternatives.

It will be recalled that the corporate income tax structure and the normal divergence between community and corporate discount rates lead to the conclusion that there exists a strong bias toward selection of a community project. over its corporate alternative. Precise knowledge of appropriate discount rates, therefore, will usually be unnecessary from the point of view of the locality. The decision will normally remain unaffected over wide ranges of discount rates. Moreover it is clear that the appropriate discount rates are the community borrowing rate and corporate cost of capital.

The results of benefit-cost studies of federal investment alternatives are more likely to be in error for there is no unanimity of opinion as to the level of the social rate of discount. Furthermore, analyzing local water projects from the national welfare viewpoint may lead to mistaken results. A social rate of discount which 
is "too low" may overstate or understate the benefit-cost ratio as may a rate which is "too high," and, unfortunately, the experts not only disagree on the precise social rate of discount but they even disagree on its theoretical underpinnings. As a result federal agencies use discount rates ranging from 3\% to 12\% (Whipple, 1968, pp. 37-45).

The following paragraphs contain a cursory examination of the existing controversy over the social rate of discount. Although only a few of the many conflicting views are presented, they should be sufficient to indicate the scope of the problem.

\section{Market Rate of Interest}

If there were no imperfections in the capital market, and if no divergences existed between social and private benefits and costs, the discount rate for public investment would be the same as the market rate of interest (Arrow, 1966, p. 14). In a world unaffected by uncertainty and risk there would be but one rate for loans of a given term. This rate would reflect both consumers' preference for a dollar today to a dollar in the future and the marginal productivity of investment. Abstracting further to a world where taxes play no part in the private decision, firms would optimize by investing to the point where the (decreasing) marginal productivity of capital equaled the (rising) marginal rate of time preference. . Under these ideal conditions the resultant market rate of interest would operate 
as the rate to use as a norm for public investment. If the marginal public investment exhibited a higher rate of return, additional public investment would be indicated. To achieve the optimal state of social welfare, marginal productivity in the private and public spheres should be equated. The "social opportunity cost" of public investment would be the private return foregone (Hirshleifer et al., 1960, pp. 176-48). Mckean argues in favor of using the market determined interest rate in the absence of capital rationing (1958, pp. 76-81).

The Conservationist Viewpoint

Other views would perhaps allow for public investment to be carried beyond the point dictated by the market rate of interest in order to conserve resources for future generations. The argument given is that the government is the guardian of the interests of unborn generations as well as the present generation. The government should therefore exhibit a lower marginal rate of substitution of future for present consumption, i.e., its marginal rate of discount should be lower than the marginal rate of time preference of the individuals comprising today's society (Pigou, 1962, pp. 23-30).

\section{Dual Individual Time Preference Rates}

Akin to the authoritarian argument of the preceding section is one which is based on the time preferences of individuals of the present generation. It hypothesizes two rates of time preference for the normal individual and is grounded on a belief in the individual 
consumer's desire to provide for future generations. An individual cares for future generations, so the argument goes, but his personal time preference rate is such that he will give up little present consumption to provide for then. However, if other individuals offer to make the sacrifice too, he will be willing to give up a greater amount. Thus the individual time preference rate differs from the collective time preference rate, and the market rate of interest loses its significance as a norm (Baumol, 1952, pp. 91-92; 1965, pp. 131-32; Sen, 1961, pp. 479-96; Marglin, 1963, pp. 95-111).

To use Sen's example suppose individual A cares for future generations but not enough to give up one unit of present consumption for three units of consumption for the generation living twenty years hence. If, however, another individual, $B$, offers also to reduce his consumption by one unit for three in the future, A may.be willing to make the one unit sacrifice, because now the future generation will receive a total of six units of consumption. This does not mean, however, that $A$ is concerned with the welfare of unborn individuals while he is completely unconcerned with the sacrifices of his living neighbor B. Actually A may consider one unit of consumption of future generations to be worth 0.3 units of his own present consumption, and he may feel B's sacrifice of one unit to be 0.7 as unpleasant to him as a sacrifice of one of his own. Saving together then the two men produce six units for the future having a present value to $A$ of 1.8 units. A's calculation of the present value cost of this 
measure, however, is only 1.7 units--one unit representing his own sacrifice and 0.7 units representing the loss he experiences because of $B^{\prime} s$ one unit sacrifice. He, therefore, feels the total present value gain exceeds the total present value cost and is thus willing to give up the one unit of consumption--something he would nat have done by himself.

This "paradox" has been criticized by Tul lock (1964, pp. 331-36) as requiring strange individual utility functions. For today's society to desire to provide for tomorrow's undoubtedly richer society is the analog of desiring to tax the poor to support the rich. It is much more likely, says Tullock, that individual preferences will gravitate toward supporting today's poor, or, perhaps through foundations, tomorrow's poor. It is unlikely, he feels, for the individual to wish to support all people of the future generation.

Other Views on the Discount Rate

Krutilla and Eckstein (1958, pp. 78-130) calculate a social opportunity cost of federal capital by considering the impact of alternatives to federal water projects. For instance, tax reductions are hypothesized as alternatives and investment rates of return available to groups receiving the reductions are weighed into the social opportunity cost. The rate calculated with 1955 data was $5-6 \%$.

Eckstein (1958, pp. 81-90) expresses a different view in his own work. He begins with the riskless market rate of interest and 
makes allowances for risk in three ways: (1) primarily by adding a risk premium of 0.5 to $1 \%$ to the pure interest rate, (2) by shortening the period of analysis, and (3) by incorporating safety allowances in the cost and benefit streams.

Hirshleifer (et al., 1960, pp. 116-21, 139-48) begins with the pure market rate of interest estimated to be about $4 \%$ in April, 1960, but without doubt considerably higher at present, and modifies it by considering risk, equity financing and the corporate income tax to obtain a rate slightly over $10 \%$. The argument given is that, for optimal resource allocation, the public discount rate should be equal to the return demanded by the private market on utility investments. If the rate used by the government is lower, better investment opportunites exist in the private sphere. Total productivity, hence benefits to society, would be enhanced by reducing public and increasing private investment. Hirshleifer et al. feel the rate resulting from time preferences (and productivity) exhibited by the present generation need not be modified for the claims of posterity. If a disparity does exist between the market rate of interest and the rate which would properly satisfy the claims of the future, it would be better for the government to take appropriate monetary and fiscal action to drive them to equality than to use different discount rates in the private and public spheres. Equating the rates would prevent the inefficiencies which would be caused by divergent public and private 
marginal productivities of investment (1960, p. 120).

Arrow (1966, pp. 13-32) approaches the problem by noting that there is a "natural rate of interest" associated with the "natural rate of growth." Utilizing a Harrod type growth model he derives the natural rate of interest which is the sum of two terms: one the equivalent of Böhm-Bowerk's first reason for interest, the lower marginal utility of future consumption due to expected growth in wealth; and the other equal to his second reason, systematic undervaluation of future utilities. Although this natural rate of interest is the proper rate for public discounting, there is another rate for discounting returns to private investment. The rates should be different to obtain maximum welfare under the condition of steady growth--a type of "constrained" optimum limited by existing conditions. A true optimum can only be achieved if the government always uses the proper monetary and fiscal policy (including repayment of the national debt if required) to overcome divergence between true time preference and that observed in the market. Should this unlikely condition obtain, the riskless private and public rates would be identical.

Application to Local Project Analysis

Although it falls far short of exhausting the subject matter of the continuing controversy, the preceding discussion should make it quite clear that the matter of the national discount rate is not yet settled. Should an interested observer desire to compute a national 
benefit-cost ratio for a local project, he would have to recognize that his answer may or may not indicate true efficiency or inefficiency. Using a "reasonable" range of discount rates he may find that the ratio always falls above or below unity; however, he might well discover a ratio less than one for some rates and greater than one for others. Should this occur he could only guess as to which answer is correct.

Fortunately economic analysis from the local viewpoint is not likely to encounter such ambiguity. The corporate income tax, which helps obscure the national discount rate, can be given some credit for simplifying the local problem.

\section{Conclusions}

The basic proposition of this chapter has been that benefitcost analysis is an appropriate procedure to use in evaluating a community's investment in water projects. Since water projects are long-lived, with cost and benefit streams extending many years into the future, costs and benefits must be discounted to obtain comparability. The cost figure relevant in the comparison was called the present value unit cost of water, which was viewed as an internal price just sufficient to cover all costs associated with the water project. It was further argued that the rate at which costs and outputs should be discounted is the "cost of capital" to the organization undertaking the project. Although the corporate "cost of capital" has a definite meaning, the difficulties involved in its 
measurement require the use of a range of discount rates to approximate the "true" cost of capital.

Water replacement projects may be undertaken by large water users on an individual basis or by collective community action. Thus the particular comparison undertaken in this paper was between a corporate project and a non-profit community project. It was shown that, under the assumptions of constant returns to outlay and equality of the costs of capital, the present value unit cost of water is lower for the corporate than for the community project. This conclusion was seen to result from the corporate income tax structure. However, since the unit cost of water for the corporate project was found to be greater than the unit cost of water for the community project reduced by the product of the corporate tax rate and the community project's unit cost, the basic conclusion was that the benefit-cost ratio for the community exceeds unity, hence it is in the community's best interest to decide in favor of the collective project. In other words, the benefits to the community, measured by the cost of the best corporate alternative, exceeds the after-tax costs associated with purchasing from the community project. Inasmuch as the community project will be larger than individual corporate projects, increasing. returns to scale in the production of water strengthen the advantage of the community project. Decreasing returns to scale, on the other hand, work to the advantage of the smaller corporate project decreasing the community benefit-cost ratio. It was further argued that such 
differences in the cost of capital as are likely to exist, operate in favor of the community project.

The method developed was then applied to a numerical problem. For cases likely to be relevant--lower costs of capital to the community than to the corporate project--community benefit-cost ratios exceeded unity by a substantial margin. It was then shown that construction and consequently maintenance costs for the community project must be a great deal higher than those of the corporate project to eliminate the advantage of the community project. Thus, although diseconomies of scale weaken the conclusion that it is more economical for the corporation to purchase water from the community project, they must be quite strong indeed before the conclusion is reversed. In short, the community project is found to have an inherent cost advantage resulting from the corporation income tax structure. Moreover, this advantage is likely to be strengthened by a lower cost of capital for the community than for the corporate project.

Finally, it was shown that the community benefit-cost ratio differs from a benefit-cost ratio computed to reflect the national welfare. A project which is justified from the community standpoint may not be efficient for the nation as a whole. However, the national computation is more likely to yield ambiguous results than is the local analysis because, as yet, there is no consensus on the level of the nation's "social rate of discount." 


\section{CHAPTER IV}

\section{THE CENTRAL AND WEST COASTAL BASINS}

\section{OF LOS ANGELES: A CASE STUDY}

Population growth and industrial development have been accompanied by an increasing utilization of the limited resources supplied by nature. Water is one such resource. Although for some regions water has always been a scarce resource, a lack of water in potable form has not usually been a deterrent to regional economic development. The growth process, however, has affected the relative supply of water in two ways: increasing population and industrialization have increased the demand for water, while, simultaneously, the discharge of human and industrial wastes has reduced its usable supply. Since the distribution of population and its growth pattern has not coincided with the natural occurrence of water, some areas have felt the pressure of population and industrial growth on limited water supplies while other areas have continued to enjoy a relative abundance. The South Coastal area of California generally provides an example of an area that quite early experienced a relative scarcity of. water. Hydrographically, the area is isolated by high mountains that prevent large rivers from entering (Hirshleifer et al., 1960, p. 293). In addition, the area is semi-arid with an annual mean precipitation of 18 inches. Superimposed upon these desert-like conditions is a rapidiy 
growing population and developing industrial complex.

The West Coast and Central Basins extend over 470 square miles of the Coastal Plain in Los Angeles County. On the inland side the surface elevation of the basins is between 200 and 300 feet above mean sea level. There is a gradual slope of 10 to 20 feet per mile down to the Pacific 0cean. The two basins are geologically separated by the Newport-Inglewood Fault which forms an imperfect barrier to water transmission in the major aquifers of the basins. Most of the water production in the West Coast Basin is obtained from the merged Silverado zone of the lower and middle Pleistocene age. The "main aquifer" in the Central basin is equivalent to, but separated by the fault from, the Silverado aquifer. The Silverado aquifer consists of rock formed from marine deposits of sand, silt and clay, some one million years ago. The Silverado aquifer merges with the ocean floor a short distance offshore. The Central Basin main aquifer does not outcrop in the ocean; however, it is interconnected, in some areas, with overlying aquifers which do merge with the ocean floor (Milne, 1968, pp. 127-31).

The experience of Southern California is important in that some areas have recently begun to experience, and still more areas in the near future will begin to experience, the types of water problems that have faced Southern California for many years. An economic evaluation of the measures undertaken by Southern California in dealing with its water problems, therefore, is of value as a guide to these 
other areas. To survey, in detail, measures taken by the entire area, however, is far too large a task for such a limited study. Instead this study focuses on only a part of California's South Coastal area. Specifically examined are the measures taken to protect and supplement the water supply of the Central and West Basin Replenishment District of Los Angeles County (Figure 4-1). Approximately 2.9 million people, or some forty percent of the population of metropolitan Las Angeles, reside within the District which has been an area of rapid population growth and industrialization.

Water use within the District has increased steadily, rising from about 395,000 acre-feet in 1950 to approximately 560,000 acrefeet during the water year ending on September 30, 1965. The water supply consists of ground water extracted from the two Basins that underlie the District and give it its name and, in recent years, imported river water. As the demand for water has increased it has been met by an increasing reliance upon imported water. In 1950, for example, the direct use of imported water amounted to only 74,000 acre-feet, but by 1965, 287,000 acre-feet of imported water, or slightly more than 50 percent of the total used, was delivered directly. Moreover, imported water has been an important source of recharge for the ground-water basins.

Currently, the West and Central ground-water basins yield an 


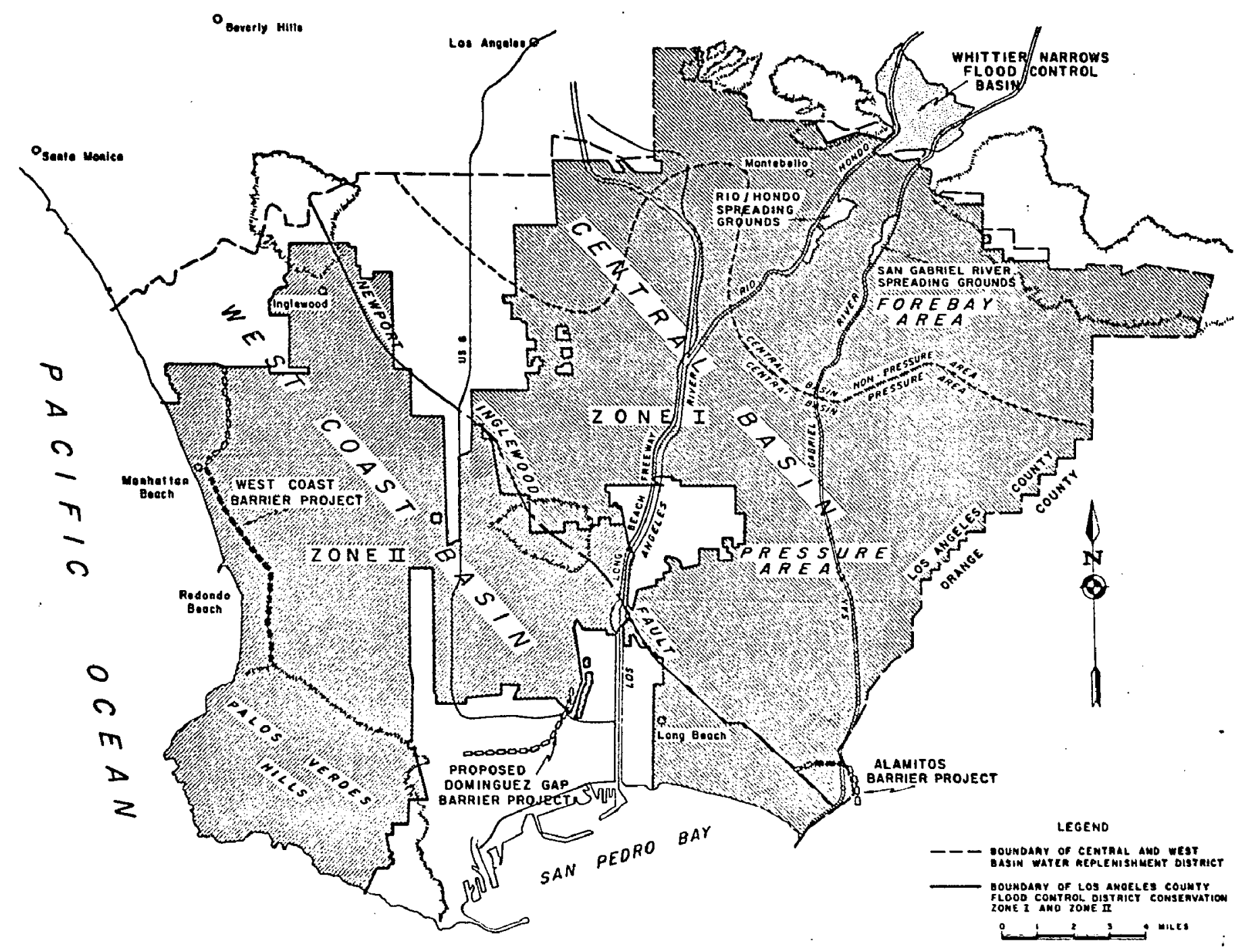

FIGURE 4-1. Central and West Basin Water Replenishment District, Los Angeles County, California 
annual production of 280,000 acre-feet of ground water. As natural recharge is not sufficient to sustain production at this leve1, large amounts of imported water, local runoff and small amounts of reclaimed sewage are spread in the forebay, or non-pressure area and join the body of ground water in the aquifers of the seaward pressure area. However, the location of principal well fields in the pressure area at some distance from the forebay has meant that spreading alone has not been sufficient to prevent intrusion of ocean-water at existing levels of production. As a consequence, two fresh-water injection barriers have been constructed and these serve as an additional source of recharge.

Direct delivery of Colorado River water via the Metropolitan Water District's Colorado River Aqueduct is the principal source of imported water. In addition, about 25,000 acre-feet of water is obtained through the Whittier Narrows from the Upper San Gabriel Valley. Finally, that part of the District that lies within Los Angeles proper also receives Owens River-Mono Basin water from the Sierra Nevada mountains which is commingled with ground water from the San Fernando Valley and delivered through the Los Angeles Aqueduct (Central and West Basin Water Replenishment District, 1966, pp. 25-29).

The hydrographical characteristics of the Replenishment District combined with its high population density and industrial base have led to a high cost of water. Bookman and Edmonston (Central and West Basin Water Replenishment District, 1967, pp. 12-14), Consulting Civil 
Engineers for the Central and West Basin Water Replenishment District, estimate that the capital investment in local water facilities in the District totals $\$ 423$ million (reproduction cost-new). The annual total cost of ground-water well production, including cost of operation, maintenance and amortization for the wells as well as for the spreading and barrier facilities is approximately $\$ 51$ million. To this must be added a $\$ 14$ million yearly cost of purchasing imported water, a basic M.W.D. tax of $\$ 9$ million, which does not include special "back taxes" which are paid by areas of the District annexed to the M.W.D. subsequent to its inception, and approximately $\$ 3$ milition in yearly earnings of private water companies. The resulting total cost of $\$ 77$ million divided by the current annual use of about 600,000 acre-feet yields an average cost approximating $\$ 130$ per acre-foot. Averages, however, may be highly misleading and the average cost quoted for water in the Replenishment District is no exception. The purpose of this case study is, first to examine in detail average and marginal costs of water both to individual users and to the District as a whole. Efficient utilization of water requires that the limited supply be allocated in such a way that the value of an increment be the same in each use and be equal to its cost to society. A second purpose of this study is to determine to what extent existing arrangements either aid in or hinder efficient allocation. To these ends an analysis is first made of the average and marginal costs of ground water to ground-water producers and then private and social 
costs of ground-water production are compared, drawing implications for economic efficiency. Next, the cost of imported water is examined and the pricing practices of the Metropolitan Water District of Southern California are analyzed. Finally, the question of the conjunctive use of water is explored, and the rationing of ground-water through quotas is compared with a pumping assessment alternative.

Ground Water

The Central and West Coast ground-water basins are fed naturally by percolation in the forebay areas located in the northeastern part of Central Basin. Originally, water moved through the aquifers to the south and west in a seaward direction. About 10,000 acre-feet per year flowed across the Newport-Inglewood fault, which separates the two basins, into the West Coast Basin. Some water also flowed from the Central Basin into the ground-water basins of Orange County to the south. Fresh water from the basins finally moved into the Pacific Ocean at points of aquifer outcrop.

From modest beginnings late in the last century, ground-water production increased until, in the 1930's, withdrawals began to exceed total recharge. As water levels in the West Coast Bas in declined, the movement across the fault from the Central Bas in increased to its present level of 20,000 to 25,000 acre-feet each year. Further, increased production in the Central Basin has reversed the flow across the Orange County line so that now approximately 29,000 acre-feet of water moves annually from Orange County into Central Basin. Of more 
significance, pumpage in excess of natural recharge reversed the natural seaward gradient and sea water began to move into the aquifers along the coast line, causing the abandonment of some wells in coastal communities and threatening contamination of much of the remainder of the ground-water basins (Ostrom, E., 1965, pp. 110-112). Quite early, private water companies, county waterworks districts, cities, industrial plants, and concerned private citizens became involved in efforts both to preserve and to supplement the existing water supply (0strom, V., 1953, pp. 116-122). The execution of each scheme occasioned the formation of some new agency or the assignment of new responsibilities to existing agencies. No existing agency was given overall authority nor was any new agency created with such powers. Despite this proliferation of agencies and division of responsibilities, however, the handling of the basins' water problems has been well coordinated through voluntary agreement among the agencies (Bookman, 1967, pp. 5-22).

Four principal measures have been taken to protect the groundwater supply. First, facilities were constructed for the capture and spreading of local runoff for percolation into the principal aquifers. During the period 1938 through 1966, an annual average of 27,000 acrefeet of runoff was conserved and spread. Currently runoff conservation is averaging about 38,000 acre-feet per year (Milne, 1968, p. 139). The wide variation in precipitation and hence in the availability of local runoff prompted the District to seek a supplemental source of 
water for spreading. Thus, a second measure which has been taken is the purchase of water for spreading. In recent years an average of approximately 130,000 acre-feet has been purchased for spreading in the forebay areas. Most of this has been Colorado River water purchased at special off-peak rates from the Metropolitan Water District, but some 15,000 acre-feet of reclaimed sewage also is spread each year (Central and West Basin Water Replenishment District, 1966, p. 54).

Another measure was the adjudication of ground water rights, first in the West Basin and then in the Central Basin, in an attempt to fix maximum production levels and to ration the existing supply. An interim agreement executed on March 1, 1955, voluntarily restricted pumping in the West Coast Basin. On October 1, 1961, 1itigation was completed and adjudicated water rights were established totaling $64,137.55$ acre-feet per year. An agreement to restrict production in the Central Basin became effective on October 1, 1963, and final judgment was rendered effective October 1, 1966, limiting total water pumpage to 217,400 acre-feet per year. Current annual extractions closely approximate the total adjudicated rights for the two basins (Milne, 1968, pp. 133, 139).

The fourth and most recent measure has been the construction of two fresh-water injection barriers at points of salt-water intrusion. The first barrier project, ultimately an 11-mile string of injection wells now (1969) about 70 percent complete, built to protect the West Basin, utilizes about 45,000 acre-feet of Colorado 
River Water, while 5,000 acre-feet are injected in the one-mile Alamitos barrier project, protecting a portion of the Central Basin (Bruington, 1968, p. 162). In addition, a third barrier project has been proposed to protect the West Coast Basin at Dominguez Gap (Central and West Bas in Water Replenishment District, 1966, p. 20). Despite the measures taken to protect existing ground water supplies, it has been necessary to meet the District's growing demand for water by importing increasing amounts of Colorado River water.

Each of these undertakings involve costs and, with the exception of adjudication, the costs are covered by annual payments in the form of ad valorem taxes, pumping assessments, or direct payments for purchased water. The cost to any user must be determined by adding ad valorem taxes to the direct cost of producing or purchasing water.

\section{Costs to Water Users}

Direct Costs to Ground-Water Users

The direct cost of ground water to an individual producer includes: (1) capital costs associated with drilling and well completion, (2) pumping costs, and (3) the Central and West Basin Water Replenishment District pumping assessment. Capital costs per acre-foot produced are affected by a number of variables, depth and diameter of the well, type of pipe and appurtenances and, most important, the extent of utilization. Thus any estimate of average capital recovery costs is quite arbitrary. A figure of $\$ 2.80$ per acre-foot has been 
taken as representative for a firm producing between 1,000 and 1,400 acre-feet of ground water per year. ${ }^{1}$ Pumping costs have been estimated at about $\$ 7.00$ per acre-foot on the basis of data obtained from the Los Angeles Flood Control District. The Replenishment District's pumping assessment is based upon the annual replenishment needs of the basins. For the water year 1966-67, the assessment was $\$ 6.20$ per acre-foot (Central and West Basin Replenishment District, 1966, p. 63). Thus, the average producer of ground water with completed wells bears a direct cost of $\$ 16.00$ per acre-foot of which $\$ 13.20$ per acre-foot represents short run variable costs.

Indirect Costs to Ground-Water Users

Several special ad valorem taxes provide revenue to finance the District's water program. Since these taxes are levied on property values, the amount of tax paid is independent of the amount of water used by individual consumers and may be treated as a fixed cost that varies only when tax rates or assessed property valuations vary. This is important: It means that a substantial portion of the cost of water is made independent of water use and is borne by the property owner.

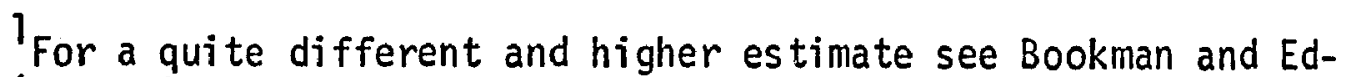
monston (Central and West Basin Water Replenishment District, 1967, p. 10). The estimate in this study is based upon figures obtained from the Los Angeles Flood Control District in 1966. 
An ad valorem tax is levied to support the Los Angeles Flood Control District's benefit Zones I and II, which together encompass most of the Replenishment District. Receipts from this tax are used to purchase replenishment water and to finance the construction of barrier projects. In fiscal 1967, the rate was $\$ 0.05$ per $\$ 100$ of the assessed valuations of land and improvements. The Flood Control District's fund is also supported by an ad valorem levy, and a part of this revenue is used to finance spreading operations. That portion of the general fund levy used for spreading was estimated to be $\$ 0.00369$ per $\$ 100$ of assessed valuation of land and improvements in fiscal $1967 .^{2}$

The Metropolitan Water District also levies property taxes to meet a portion of the current and expected future cost of importing water into the area. ${ }^{3}$ In fiscal 1967, the rate was $\$ 0.14$ per $\$ 100$ of assessed valuation on all taxable property, including "personal property" as well as land and improvements. In addition, a special

2 The rate is calculated as follows: the cost of spreading 130,000 acre-feet of purchased water, including sewage, is estimated to be $\$ 1$ per acre-foot. Estimated cost of spreading the current average of about 38,000 acre-feet of runoff is $\$ 10$ per acre-foot. Thus the total cost of spreading operations including amortization of facilities, is approximately $\$ 510,000$, representing 2.46 percent of the $\$ 20,736,944$ collected from the full general fund levy, or \$0.00369 of the $\$ 0.15$ per $\$ 100$ total tax rate.

${ }^{3}$ The balance is paid directly by the West Basin and Central Basin Municipal Water Districts which function as wholesaling agencies. These districts in turn receive payments from users. 
assessment for "back taxes" is collected from those parts of the basins that were annexed to M.W.D. subsequent to its initial deliveries of Colorado River water to the Los Angeles metropolitan area. These "back taxes" vary widely within the District, now ranging from zero to $\$ 0.13$ per $\$ 100$ of assessed valuation on all taxable property, and will continue for some years into the future: In the originally annexed portion of the West Coast Basin until 1978; in the Central Basin original area until 1984.

Finally the Central and West Basin Water Replenishment District itself levies a property tax to cover the administrative costs connected with the District's replenishment activities; the rate for fiscal 1967 was $\$ 0.002$ per $\$ 100$ of assessed valuation (Los Angeles County, 1967, pp. 49-76). The average ratio of assessed value to actual value or selling price for residential property is about 20 percent in Los Angeles County. It is believed that the assessment ratio for industrial property is considerably higher--in the vicinity of 45 percent of market value. The assessment ratio for public utilities is thought to be close to 50 percent. By 1971, however, the state plans to have al1 assessments equalized at 25 percent of market value (personal conversation, Mr. Frank Thi11, California Taxpayers' Association).

\section{Average Total Costs of Ground Water}

Estimated average total costs for ground water production are shown in Tables 4-1 and 4-2 for companies with market values of $\$ 10$, 50 , and 100 million and for selected annual pumping rates from 50 to 
TABLE 4-1. Average Total Water Costs to Ground-Water Producers-M.W.D. Tax $\$ 0.14$ per $\$ 100$

(Dollars per Acre-Foot)

\begin{tabular}{rrrr}
\hline $\begin{array}{c}\text { Yearly Ground } \\
\text { Water Production } \\
\text { (Acre-Feet) }\end{array}$ & \multicolumn{4}{c}{ Plant Valuation-Market Value } \\
\cline { 2 - 3 } 50 & $193.16,000,000$ & $\$ 50,000,000$ & $\$ 100,000,000$ \\
100 & 103.18 & 837.48 & $1,642.88$ \\
500 & 33.09 & 425.34 & 828.04 \\
1,000 & 24.18 & 97.52 & 178.06 \\
5,000 & 16.58 & 56.40 & 96.67 \\
10,000 & 15.68 & 23.02 & 31.08 \\
& & 18.91 & 22.93 \\
\hline
\end{tabular}


TABLE 4-2. Average Total Water Costs to Ground-Water Producers--M.W.D. Tax $\$ 0.27$ per $\$ 100$

(Dollars per Acre-Foot)

\begin{tabular}{rrrr}
$\begin{array}{c}\text { Yearly Ground } \\
\text { Water Production } \\
(\text { Acre-Feet })\end{array}$ & \multicolumn{3}{c}{ Plant Valuation--Market Value } \\
\hline $50,000,000$ & $\$ 50,000,000$ & $\$ 100,000,000$ \\
100 & 310.16 & $1,422.48$ & $2,812.88$ \\
500 & 161.68 & 717.84 & $1,413.04$ \\
1,000 & 44.79 & 156.02 & 295.06 \\
5,000 & 30.03 & 85.65 & 155.17 \\
10,000 & 17.75 & 28.87 & 42.78 \\
& 16.27 & 21.83 & 28.78 \\
\hline
\end{tabular}


10,000 acre-feet. Detailed methods of calculation are presented in the Appendix, Example 1. For simplicity, the effects of corporate income tax on after-tax costs are ignored; however, no qualitative changes would result from their inclusion in the analysis of this Chapter.

The calculations in Table 4-1 use the minimum or normal M.W.D. levy, while those in Table 4-2 use the maximum rate of $\$ 0.27$ per $\$ 100$ of assessed valuation. A comparison of the tables indicates that location within the District makes a substantial difference in unit costs of water. For example, a user with a $\$ 50,000,000$ plant producing 1,000 acre-feet per year, but located in an area not paying "back taxes" to the M.W.D. had a cost of $\$ 56.40$ per acre-foot, whereas the cost per acre-foot for a comparable plant located in an area subject to the highest M.W.D. levy is $\$ 85.65$.

The really important point demonstrated by Tables 4-1 and 4-2 is that the effective cost of ground water per acre-foot varies inversely with ground water production. Again, the reason is that a not insignificant part of the cost is borne in the form of ad valorem or property taxes and is thus independent of water use. What this means is that property owners who do not use ground water, in effect, subsidize ground-water users. Such an arrangement raises questions of both equity and economic efficiency. On equity grounds the heavy reliance on ad valorem taxes has been justified "by those who made the decision on the assumption that the land value had increased as a 
result of the assurance of a firm water supply." In effect, it was "assumed that a positive externality had been created of benefit to the taxpayer which was as large or larger than the tax burden" (Ostrom, E., 1965, pp. 570-71). No attempt is made to appraise this equity argument; at best it appears questionable.

The most important criticism of the extensive use of ad valorem taxes is that it leads to an inefficient allocation of resources. Consider first the direct cost of producing an additional acre-foot of ground water to the water user. Provided his wells are being operated at a level below capacity, the cost to him of producing an additional acre-foot of water is the sum of the pumping cost and the District's pumping assessment or $\$ 13.20$ per acre-foot. This figure may be taken as representative of what the economist refers to as short-run marginal cost--the cost of increasing production by a small amount. By considering the short-run marginal cost to be constant up to well capacity, this study neglects the effect of increased pumping on water levels and hence upon pumping costs. A justification for doing so is that given a high coefficient of aquifer transmissibility, small incremental increases in pumping by one producer will have negligible effects on water levels. 4

${ }^{4}$ Contrast this to Hirshleifer et al. (1960, p. 65) who consider the case of an individual producer whose pumping does draw down his own water levels, generating a rising marginal cost curve. Here falling. water levels also affect his neighbor's cost pushing marginal social costs above marginal private costs. This possibility is not included in the analysis of this Chapter. Moreover, the assumption is made 
Once the total capacity of a producer's wells is reached, he can increase production only by expanding the existing capacity of his well field. The cost of producing a small increment of water thus rises sharply at the capacity level or, as the economist would put it, marginal cost is discontinuous at the capacity output. Decisions to expand capacity or for that matter to maintain capacity intact involve a consideration of capital costs. Capital costs per unit vary immensely with the level of production between well additions, reaching a minimum of $\$ 1.64$ per acre-foot ${ }^{5}$ as an existing well field is used to capacity. Thus, the minimum capital recovery cost that must be considered in decisions to alter existing capacity is $\$ 1.64$ per acre-foot. Addition of this figure to short-run average variable, or marginal, costs yields the minimum long-run average variable $\cos ^{6}$ of $\$ 14.84$ per acre-foot to the individual producers of ground water. In practice, however, well fields will not be operated at full capacity so that the unit capital recovery cost will exceed $\$ 1.64$ per acre-foot. Using an

that marginal pumping cost is the same for every pumper. It is recognized that this assumption is incorrect to the extent that there is variation in well depths measured from the land surface to the well water levels.

${ }^{5}$ This represents the unit capital recovery cost for a 2,420 acre-feet per year well used to capacity. Calculation has been made in the manner of Example 1 in the Appendix.

${ }^{6}$ In the usual case no distinction would be made between longrun average total and long-run average variable cost. The distinction must be made here because the ad valorem taxes in the costs do not vary with output either in the long or short run. 
estimate of capital recovery cost of $\$ 2.80$, an estimate of 1ong-run marginal private cost would be approximately $\$ 16.00$ per acre-foot.

To summarize the findings with respect to private costs: an important part of the total cost of ground water is fixed, or independent of the amount produced by the individual producer, in both the short and the long run. Consequently, average total costs of production vary inversely with the level of production. Average variable cost and hence marginal cost is constant in the short run, and for levels of output below capacity, can be represented as the sum of pumping costs and the pumping assessment, or $\$ 13.20$ per acre-foot. Finally, in what the economist refers to as the long run, capacity is a variable that can either be expanded by the addition of wells or contracted by failing to replace depreciating equipment. Thus in the long run capital recovery costs must be included. The figure of $\$ 16.00$ has been taken, somewhat arbitrarily, as an approximation of long-run average variable and marginal cost. The relationship between long-run average total and marginal cost is depicted in Figure 4-2.

\section{Social Cost of Ground Water}

As noted earlier, the effect of financing part of the costs of protecting and supplementing the water supply by ad valorem taxes is to transfer costs from water users to property owners generally. A second and more important effect is to cause a divergence between private and social costs. What is really significant from the standpoint of economic efficiency is the resulting discrepancy between marginal social 


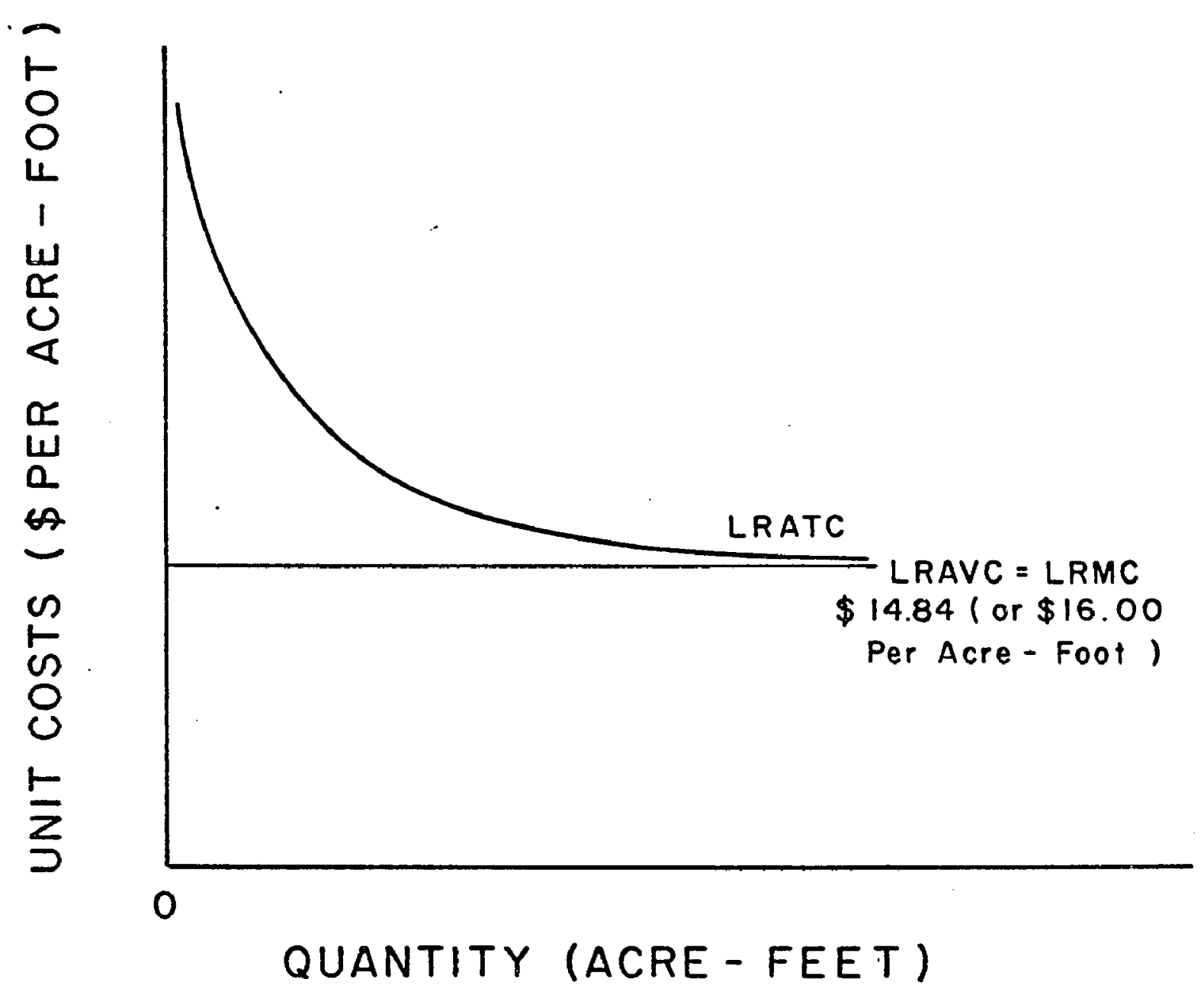

FIGURE 4-2. Ground-Water Cost Curves--Central and West Basin Replenishment District 
cost and marginal private cost. It is now appropriate, therefore, to calculate the marginal social cost of ground water, to compare it with the marginal private cost, and finally to draw efficiency implications.

Receipts from three of the ad valorem taxes are used to defray costs that, from the District's standpoint, are variable. The costs of ground-water replenishment and barrier construction are variable in the sense that they depend upon the level of ground-water production. The effect of financing these costs by ad valorem taxes is to convert them into costs that are fixed from the standpoint of water producers. A computation of estimated total and average variable social cost of ground-water production is presented in Table 4-3. The calculated figure is $\$ 25.39$--substantially higher than the $\$ 76.00$ long-run average variable private costs.

The relationship between average variable social cost and marginal social cost is more tenuous than the relationship between average and marginal private costs. In the latter case, average and marginal costs could be treated as constant and hence equal in both the short and the long run. In the former case, however, such an assumption is unwarranted. Increased production in the basins leads to reduced water levels and, as a result, higher pumping costs to all producers. Moreover, higher production levels intensify the problem of salt-water intrusion. A rising average variable social cost for ground-water implies that marginal social cost lies above average 
variable cost. Thus, although the estimated average variable cost of $\$ 25.39$ is used as a proxy for marginal social cost, it must be recognized that this figure may be well below the "true" marginal social cost.

TABLE 4-3. Total and Average Variable Social cost of Ground Water in the West and Central Bas in Replenishment District

Pumping Cost, 280,000 acre-feet, at $\$ 7.00$ per acre-foot $\$ 1,960,000$

Pumping Assessment, 280,000 acre-feet, at $\$ 6.20$ per acre-foot $1,736,000$

Capital Recovery Cost, 280,000 acre-feet, at $\$ 2.80$ per acre-foot

784,000

Zone I or II Ad Valorem Levy $2,019,000$

Los Angeles Flood Control General Fund Tax-portion financing spreading

510,000

West and Central Basin Water Replenishment District Tax 100,000

Total Variable Social Cost $\$ 7,109,000$

Average Variable Social Cost $\$ 25.39$ per acre-foot

As previously stated, efficiency in resource allocation requires that the value of an additional unit of a resource, its marginal value in use, be equal to its marginal social cost, or the cost to society of an additional unit of that resource. The marginal value in use of a given quantity of water is determined by the price that users are willing to pay to obtain that quantity. The demand curve 
for water, in other words, is a relationship between its marginal value in use and the quantity consumed. For the ultimate consumer, the demand for water depends upon his subjective valuation or tastes, income, and the relative prices of other goods. The industrial demand is a derived demand--it depends upon the demand for the outputs of the productive process. The shape and level of the business firm's demand schedule is also influenced by the state of technology and the prices of other resources or inputs. The essential point is that the quantity of water demanded is a decreasing function of the price that must be paid, either by consumers or by business firms. Put another way, the marginal value in use declines as quantity is increased.

This argument is given a diagrammatic representation in Figure 4-3. Let the curve labeled MVU represent the demand curve of any individual user of ground water, the curve $M C_{p}$ is the marginal private cost (estimated to be $\$ 16.00$ ) and the curve $M C_{S}$ is the marginal social cost, which is at least $\$ 25.39$. The individual user has incentive to increase his use to the point where the marginal cost to him is equal to his marginal value in use. At smaller quantities, the value of an additional unit of water is more than its cost to him. For greater quantities, however, the cost of additional units exceeds their value and the user would gain by diminishing his use. Thus, the quantity $Q_{0}$ represents the optimal quantity to the individual producer. At this level of use, however, the marginal social cost is 


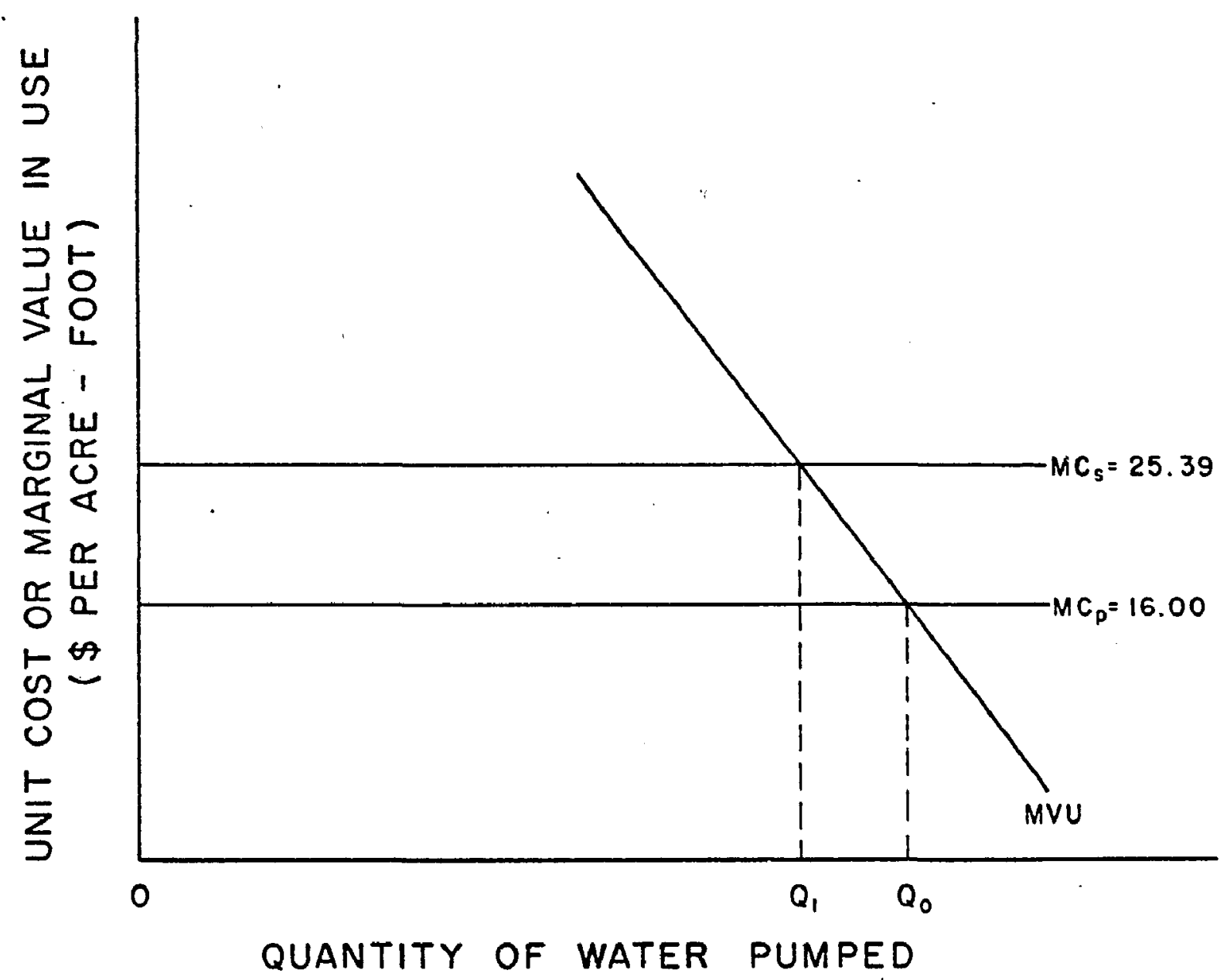

FIGURE 4-3. Ground-Water Demand-- Central and West Basin Replenishment District 
greater than the marginal value in use to the individual user. If the marginal value in use to the individual user reflects the marginal value in use to society, then cost to society of an incremental unit of water exceeds its value to society. In short, too much water is used. The effect of shifting a portion of the variable cost from the user to the property holder is to encourage an overuse of ground-water. More efficient utilization of the existing ground-water supply would be achieved by transferring part of the costs of replenishment from ad valorem taxes to the pumping assessment. As the cost to the individual user is increased, the amount.pumped will be reduced. Reduced pumping will raise water levels and diminish marginal social cost.

\section{Imported Water}

The Metropolitan Water District which was formed in 1928 to bring Colorado River Water to the South Coastal Area of California serves an area extending from the Santa Monica Mountains, just north of Los Angeles, to the Mexican border. Deliveries through the 242-mile long aqueduct, constructed at an initial cost of $\$ 181$ miliion, began in 1941. It was not until 1948, however, that the West Coast Basin was annexed to the Metropolitan Water District, and M.W.D. water was not utilized in the Central Basin until 1955 (Ostrom, E., 1965, pp. 292, 494). M.W.D. delivers water to the Replenishment District selling the water to the West Basin and Central Basin Municipal Water Districts. These agencies, in turn, act as wholesalers, selling to 
municipal and private water companies, as well as to industrial firms, at the M.W.D. price plus a charge of $\$ 0.50$ per acre-foot by the West Basin Municipal Water District and a charge of $\$ 1.00$ per acre-foot by the Central Basin Municipal Water District.

Throughout its early history, the Colorado River Aqueduct operated well below capacity. Indeed, until 1962 deliveries never exceeded one million acre-feet. Prices that covered full costs would have been prohibitive so ad valorem taxes were imposed to finance the deficit between costs and sales revenue. In fiscal 1965-66, for example, the Metropolitan Water District collected over $\$ 35$ million in ad valorem taxes while total revenue from water sales was onty $\$ 28$ million. In addition, the M.W.D. has apparently followed a discriminatory pricing policy, charging lower prices to agricultural users and for water used for replenishment; however, to some extent at least, their price differences may be due to cost differences. The rates charged by M.W.D. throughout its history are presented in Table 4-4. It should be noted that rates have risen substantially since 1948, a factor which combined with a rising quantity has meant that sales revenue has been more than sufficient to cover full cost during the three-year period ending June 20, 1966 (M.W.D., 1966, p. 193).

Despite these surpluses, it is anticipated that ad valorem taxes will not be reduced and that M.W.D. water prices will continue to rise. By 1972, the M.W.D. will begin to handle deliveries of Feather River water from Northern California at an estimated cost of 
TABLE 4-4. Metropolitan Water District Rate History (Dollars per Acre-Foot)

\begin{tabular}{|c|c|c|c|c|c|c|c|}
\hline \multicolumn{2}{|c|}{ Date } & \multicolumn{3}{|c|}{ Norma 7} & \multicolumn{3}{|c|}{ Agriculture \& Replenishment } \\
\hline From & To & $\begin{array}{c}\text { Softened \& } \\
\text { Filtered }\end{array}$ & Filtered & Untreated & $\begin{array}{c}\text { Softened \& } \\
\text { Filtered }\end{array}$ & Filtered & Untreated \\
\hline $\begin{array}{l}12-20-1940 \\
7-1-48 \\
7-1-50 \\
12-1-54 \\
5-1-55 \\
11-1-55 \\
12-1-55 \\
4-30-56 \\
7-1-57 \\
7-1-58 \\
7-1-60 \\
1-1-61 \\
1-1-62 \\
1-1-63 \\
1-1-64 \\
7-1-64 \\
7-7-65 \\
7-1-66 \\
7-1-67 \\
7-1-68 \text { (Schec }\end{array}$ & $\begin{array}{l}6-30-1948 \\
6-30-50 \\
11-30-54 \\
4-30-55 \\
10-31-55 \\
11-30-55 \\
4-30-56 \\
6-30-57 \\
6-30-58 \\
6-30-60 \\
12-31-60 \\
12-31-61 \\
12-31-62 \\
12-31-63 \\
6-30-64 \\
6-30-65 \\
6-30-66 \\
6-30-67 \\
6-30-68 \\
\text { luled Rates) }\end{array}$ & $\begin{array}{l}\$ 15.00 \\
18.00 \\
20.00 \\
18.00 \\
22.00 \\
18.00 \\
20.00 \\
20.00 \\
22.00 \\
25.00 \\
23.00 \\
25.00 \\
27.00 \\
29.00 \\
32.00 \\
34.00 \\
37.00 \\
40.00 \\
43.00 \\
46.00\end{array}$ & 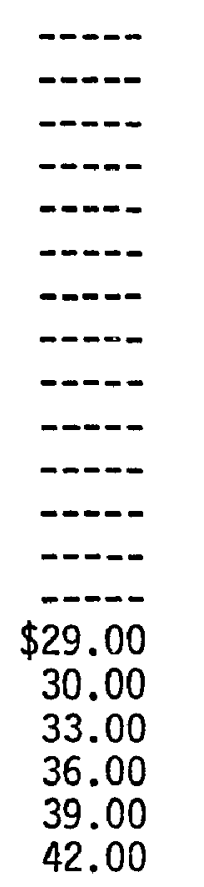 & $\begin{array}{r}\$ 8.00 \\
8.00 \\
10.00 \\
8.00 \\
10.00 \\
8.00 \\
10.00 \\
10.00 \\
12.00 \\
15.00 \\
15.00 \\
17.00 \\
19.00 \\
21.00 \\
24.00 \\
25.00 \\
28.00 \\
31.00 \\
34.00 \\
37.00\end{array}$ & 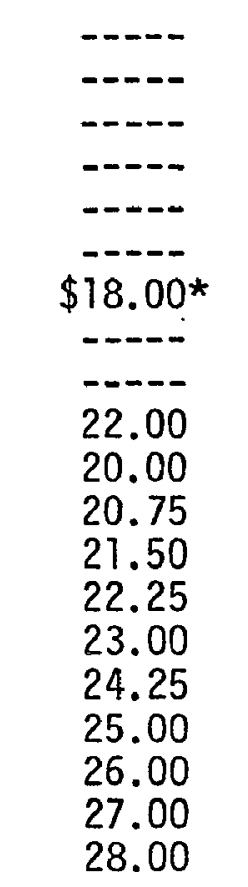 & 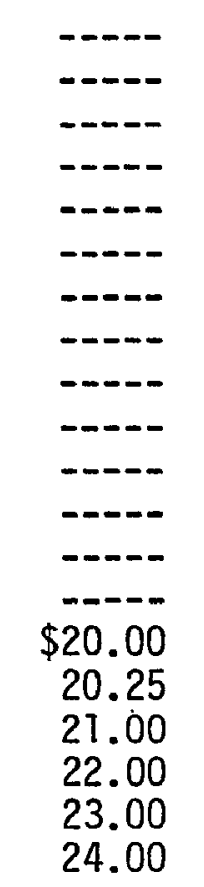 & 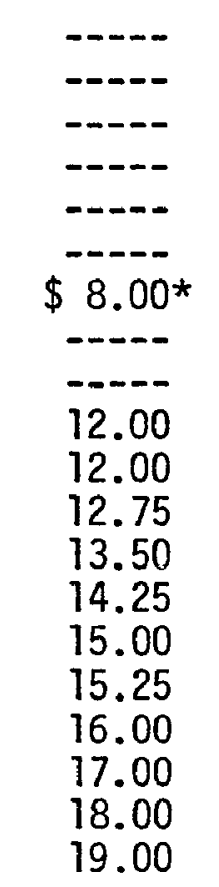 \\
\hline
\end{tabular}

*Special prices during specified period covered sales of water for surface and underground storage.

Source: Metropolitan Water District of Southern California, Annual Reports for the Fiscal Year $1940-1965$. 
\$65 per acre-foot for new water (Hirshleifer and Milliman, 1967, p. 175). Past history sugges ts that the rising cost of imported water will be met by some combination of increased price and ad valorem taxes.

Cost to Water Users

The direct cost of imported water to the user includes the price that he must pay to the municipal water district which, for softened and filtered water in fiscal 1967, was $\$ 40.50$ per acre-foot in the West Basin and $\$ 41.00$ per acre-foot in the Central Basin. In addition, the user of M.W.D. water must initially pay for a connection to a M.W.D. feeder which for a typical industrial plant located in a feeder area would cost between $\$ 30,000$ and $\$ 50,000$ (personal conversation, Clinton Milne, Los Angeles Flood Control District). If the plant is not located in a feeder area, it must also bear the cost of a line from the feeder to the plant. Furthermore, the user of imported water may need to provide storage sufficient to temporarily fill his needs in the event of a line breakdown. Thus the industrial water user has capital recovery cos.ts as well. Of course, the user of M.W.D. water also pays the same ad valorem taxes that the ground-water users must pay.

Estimated average total costs for imported water in the West Coast Basin are presented in Tables 4-5 and 4-6 for plants with market values of $\$ 10$ million, $\$ 50$ million, and $\$ 100$ million at selected use levels between 50 and 10,000 acre-feet per year. A sample calculation 
TABLE 4-5. Average Total costs of Imported Water to West Basin Water Users--M.W.D. Tax $\$ 0.14$ per $\$ 100$

(Dollars per Acre-Foot)*

\begin{tabular}{crrr}
\hline $\begin{array}{c}\text { Yearly Water } \\
\text { Use--Acre-Feet }\end{array}$ & \multicolumn{3}{c}{ P1ant Valuation--Market Value } \\
\hline 50 & $\$ 10,000,000$ & $\$ 50,000,000$ & $\$ 100,000,000$ \\
100 & 257.58 & 901.90 & $1,707.30$ \\
500 & 149.04 & 471.20 & 873.90 \\
1,000 & 62.21 & 126.64 & 207.18 \\
5,000 & 51.35 & 83.57 & 123.84 \\
10,000 & 42.67 & 49.11 & 57.17 \\
\hline
\end{tabular}

*For Central Basin add $\$ 0.50$ per acre-foot for the additional charge of the Central Basin Municipal Water District. 
TABLE 4-6. Average Total Costs of Imported Water to West Bas in Water Users - M.W.D. Tax $\$ 0.27$ per $\$ 100$ (Dollars per Acre-Foot)*

\begin{tabular}{cccr}
\hline $\begin{array}{c}\text { Yearly Water } \\
\text { Use--Acre-Feet }\end{array}$ & \multicolumn{3}{c}{ Plant Valuation--Market Value } \\
\hline 50 & $\$ 10,000,000$ & $\$ 50,000,000$ & $\$ 100,000,000$ \\
100 & 374.58 & $1,486.90$ & $2,877.30$ \\
500 & 207.54 & 763.70 & $1,458.90$ \\
1,000 & 73.91 & 185.14 & 324.18 \\
5,000 & 57.20 & 112.82 & 182.34 \\
10,000 & 43.84 & 54.96 & 68.87 \\
\hline
\end{tabular}

* For Central Basin add $\$ 0.50$ per acre-foot for the additional charge of the Central Basin Municipal Water District. 
is provided in the Appendix, Example 2. The only difference between Tables 4-5 and 4-6 is that in the former the minimum M.W.D. levy of $\$ 0.14$ per $\$ 100$ of assessed valuation is used, while the latter is based on the highest rate of $\$ 0.27$ per $\$ 100$. The differences within rows of either table, reading from left to right, indicate the effect of property values on imported water costs, whereas differences within a given column indicate the inverse relationship between use and average cost attributable to ad valorem taxes. Comparison of an entry in Table 4-5 with the corresponding entry in Table 4-6 indicates the effect of location within the bașin and hence the level of the M.W.D. ad valorem tax on unit cost. Finally, a comparison of Table 4-5 with Table 4-1 (page 105) or Table 4-6 with Table 4-2 (page 106) reveals, as indeed has much of the previous discussion, the large differential between the cost of ground water and the cost of imported water.

\section{Social Cost of Imported Water}

The short-run marginal social cost of M.W.D. water to the Central and West Coast Replenishment District is fixed by the pricing policy of the M.W.D. and for normal use was equal in fiscal 1967 to the short-run marginal private cost of $\$ 41.00$ in the Central Basin and $\$ 40.50$ in the West Basin. Long-run marginal social cost must take into account the construction of Additional feeders and connections to feeders. To the extent that these costs are borne by water users either in the forms of increased prices or initial capital outlays long-run 
marginal private costs accurately reflect social costs. To the extent that construction of new feeders by the M.W.D. are financed by ad valorem taxes, however, long-run marginal private costs fall below long-run marginal social costs. Discrepancies between social and private marginal costs of imported water, if such exist, are not of the magnitude of those between the marginal social and private costs of ground water and may, for all practical purposes, be ignored.

A more fundamental question concerns the pricing policy of the Metropolitan Water District. Does the price, or list of prices, charged by the M.W.D. correspond to the marginal social cost of imported water? This question is not easily answered. One may first question the timing of the construction of the Colorado River Aqueduct. Economic justification would have required that the total after-tax present value unit cost of Aqueduct water, delivered to the South Coastal Area be no higher than the after-tax unit cost of the existing supply at the time deliveries first began. The Aqueduct operated well below capacity for many years after deliveries began, despite the financing of the major portion of its cost by ad valorem taxes. This, coupled with the fact that M.W.D. prices alone. have exceeded groundwater costs for many years, is evidence that construction of the Aqueduct was premature, and that capacity was overbuilt. In short, the marginal social cost of Colorado River water greatly exceeded its marginal value in use.

Once the Aqueduct was in operation, however, the costs of its 
construction became irrelevant for pricing policy. Provided that the Aqueduct is operated at less than capacity, the marginal social cost of delivering an additional acre-foot of water to southern California is simply the addition to operating costs plus the cost of such additional feeders and other facilities as may be required. An attempt was made to estimate this marginal cost from data taken from the annual reports of the Metropolitan Water District from 1946 to 1965. Since annual sales consist of sales of both softened and filtered, and untreated water, an output index was constructed by weighting each type of water by $i$ ts average price, the underlying assumption being that price differentials reflected cost differentials. ${ }^{7}$ Second, to compensate for changes in the price level, all costs, except depreciation and interest, were deflated by an index of earnings in contract construction in California. A scatter diagram relating deflated cost figures to output was then plotted (Figure 4-4).

The scatter of points appeared approximately linear so that a linear estimating equation was used and the parameters were estimated by a "least-squares" regression of deflated cost on quantity. The resulting regression equation is

7 This assumption is not entirely accurate. Part of the average price differential probably resulted from price discrimination based on demand differentials. The remaining differences between M.W.D.'s prices for "normal" and "agriculture and replenishment use," however, are clearly not due to discrimination. Deliveries through laterals extended into the highly populated areas are undoubtedly more costly than agricultural and replenishment deliveries. 


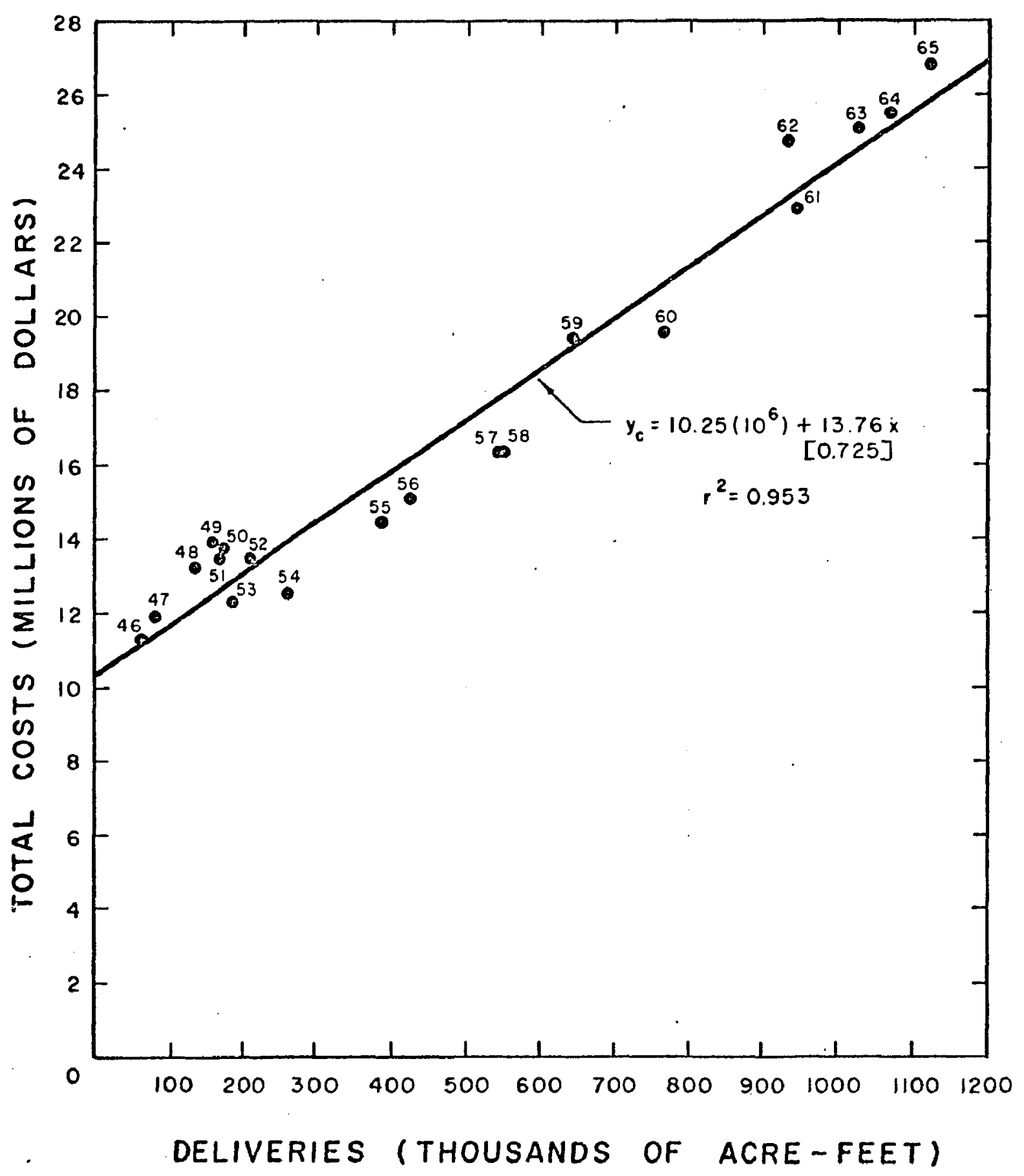

FIGURE 4-4. Metropolitan Water District Adjusted Total Costs and Adjusted Output, 1946-1965. (Quantity, 1964-65 = 100; Price 1965 = 100) 


$$
y_{c}=10.25\left(10^{6}\right)+13.76 x
$$

the coefficient of determination $r^{2}$ is 0.953 , the standard error of the regression is $1.16\left(10^{6}\right)$, and the standard error of $b$, the marginal cost es timate of $\$ 13.76$, is $\$ 0.725$.

Although application of the $t$ test to the slope of equation (4-1) would lead to acceptance of $b \neq 0$ at the 0.001 level of confidence, visual inspection of the data suggests that the high correlation between quantity and cost might be due to serial correlation in the unexplained residuals. Computation of a Durbin-Watson statistic of -0.0458 apparently verifies lack of randomness in the residuals (Durbin and Watson, 1950, pp. 409-28, and 1951, pp. 159-78).

The first differences of deflated cost were then regressed upon first differences of adjusted quantities to compensate for the auto-correlated errors (Cochrane and Orcutt, 1949, pp. 32-61). A scatter diagram for this regression is given in Figure 4-5. The first difference procedure yields the estimating equation

$$
\begin{array}{r}
\Delta y_{c}=5.338\left(10^{4}\right)+13.73 \Delta x . \\
{\left[34.657\left(10^{4}\right)\right][4.487]}
\end{array}
$$

The Durbin-Watson statistic for the regression of first differences is 1.4031 permitting acceptance at the 0.02 level of the hypothesis that 


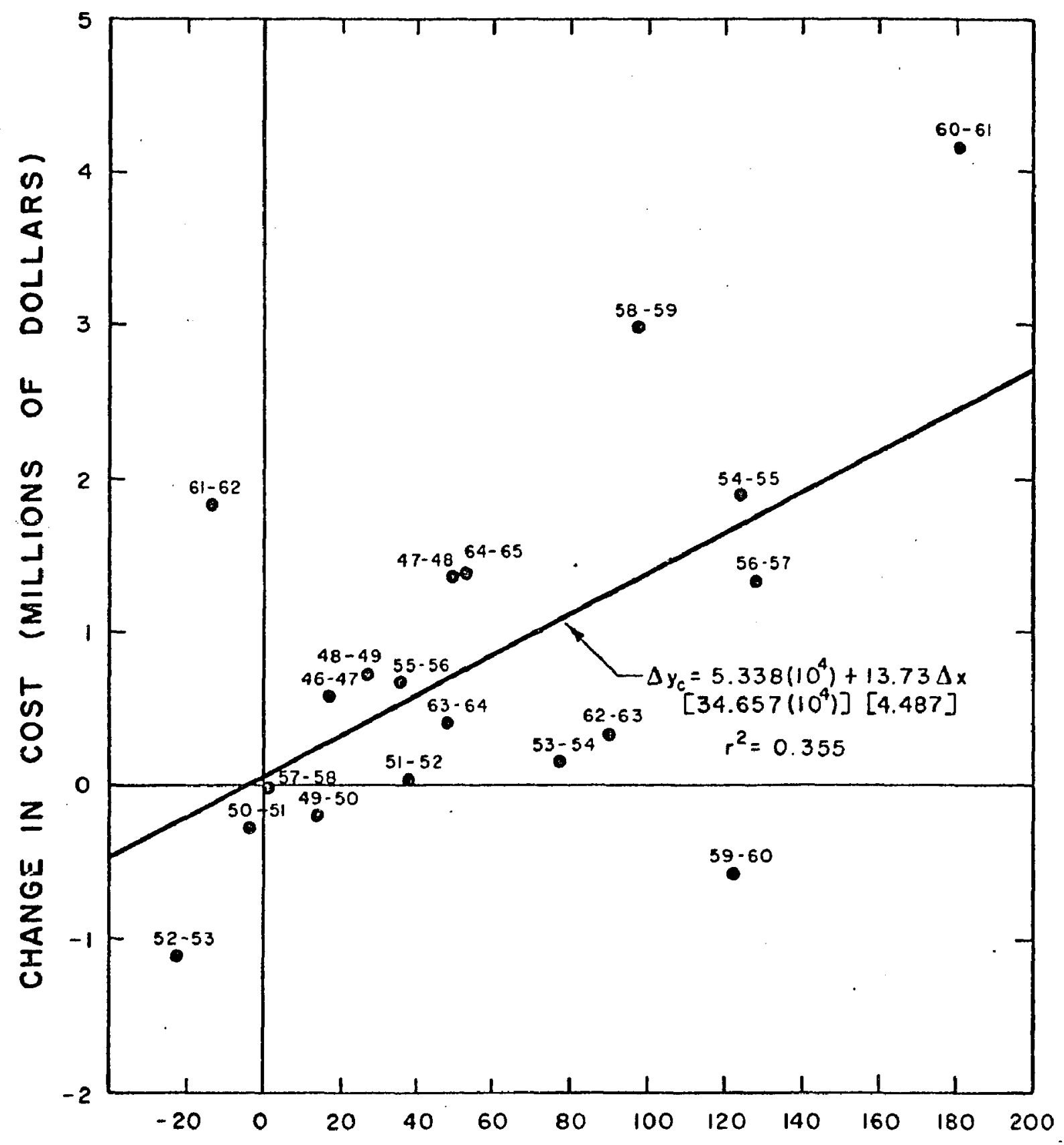

CHANGE IN DELIVERIES (THOUSANDS OF ACRE-FEET)

FIGURE 4-5. Metropolitan Water District. First Differences of Adjusted Total Costs and Adjus ted Output, 1946-1965. (Quantity, $1964-65=100$; Price $1965=100$ ) 
residuals are now random. The slope of the regression of first differences is almost identical to the slope of expression (4-1) which utilized actual magnitudes, although the $r^{2}$ value has been reduced to 0.355 and the standard error of $b$ has been increased to $\$ 4.487$. Despite this large standard error the estimate of the slope $b$ is still significantly different from zero at the 0.01 level. And a test of significance of the intercept. leads to acceptance of the hypothes is that it is not significantly different from zero, as indeed it should not be, at the 0.01 level of confidence.

It appears then that $\$ 13.73$ per acre-foot, in 1965 prices, can be taken as a reasonable point estimate of the marginal cost of M.W.D. water for the period prior to 1962 when the Colorado River Aqueduct was operated with excess capacity. A comparison of the marginal cost of M.W.D. and the lowest rate, the rate for untreated water for agriculture and replenishment, charged by the M.W.D. is provided by Table 4-7. To obtain comparability, M.W.D. rates have been deflated by the price index used to deflate costs, so that all rates are in 1965 dollars. Only in 1956 is the price (adjusted) charged for untreated water lower than the estimated marginal cost of $\$ 13.73$ an acre-foot. Since, however, the estimated marginal cost is an average applicable to both treated and untreated water, it seems reasonable to believe that the marginal cost of untreated water is less than the $\$ 13.05$ charge (adjusted) in 1956.

In summary, it is concluded that at the time the decision was made to construct the Colorado River Aqueduct, the value of water 
TABLE 4-7. M.W.D. Rates for Untreated Water for Agriculture and Replenishment in 1965 Dollars

\begin{tabular}{lrcc}
\hline Year & $\begin{array}{c}\text { M.W.D. } \\
\text { Rate }\end{array}$ & $\begin{array}{c}\text { Price Index } \\
1965=100\end{array}$ & $\begin{array}{c}\text { M.W.D. Rate in } \\
\text { i965 Dollars* }\end{array}$ \\
\hline 1946 & $\$ 8.00$ & 38.1 & $\$ 21.00$ \\
1947 & 8.00 & 39.7 & 20.15 \\
1948 & 8.00 & 41.3 & 19.37 \\
1949 & 8.00 & 42.9 & 18.65 \\
1950 & 8.00 & 44.7 & 17.90 \\
1951 & 10.00 & 47.8 & 20.92 \\
1952 & 10.00 & 50.6 & 19.76 \\
1953 & 10.00 & 54.3 & 18.42 \\
1954 & 8.00 & 56.3 & 14.21 \\
1955 & 8.00 & 58.1 & 13.77 \\
1956 & 8.00 & 61.3 & $13.05 *$ \\
1957 & 10.00 & 65.2 & 15.34 \\
1958 & 12.00 & 70.0 & 17.14 \\
1959 & 12.00 & 73.7 & 16.28 \\
1960 & 12.00 & 78.3 & 15.33 \\
1961 & 12.75 & 82.6 & 15.44 \\
1962 & 13.50 & 86.6 & 15.59 \\
1963 & 14.25 & 90.9 & 15.68 \\
1964 & 15.00 & 95.3 & 15.74 \\
1965 & 15.25 & 100.0 & 15.25 \\
\hline & & & \\
\hline & & & \\
\hline
\end{tabular}

*To be compared with the M.W.D. marginal cost of $\$ 13.73$ in 1965 dollars.

Source: Metropolitan Water District of Southern California, Annual Report for the Fiscal Year, 1946-1965; U.S. Department of of Labor, Bureau of Labor Statistics, 1967, Employment and Earnings Statistics for States and Areas, 1939-1966, p. 41. (First three years of price index estimated). 
was substantially below the marginal cost of the new source of supply. Once the Aqueduct was built and while it operated below capacity, the price charged was in excess of marginal social cost. ${ }^{8}$ In the early years of the Aqueduct's operation a more efficient allocation of resources could have been achieved by charging lower prices for Colorado River Water, but the early reliance on ad valorem taxes and the practice of price discrimination appear justified on the grounds of economic efficiency even if such practices do raise questions of equity.

Since 1962, however, the Colorado River Aqueduct has operated close to its rated capacity of approximately 1,200,000 acre-feet per year and beginning in 1974, the M.W.D's Colorado River water rights are scheduled to decline gradually to 550,000 acre-feet in $1990 .^{9}$ The estimated marginal cost figure of $\$ 13.73$ which was applicable during the years that the system was operated with excess capacity is no longer relevant. What is relevant is the social cost of adding to existing sources of supply. The California Water Plan, undertaken to augment the water supply of Southern California among other purposes, involves the construction of the California Aqueduct

${ }^{8}$ For a different view see Hirshleifer et al. (1960, p. 306), who use incremental operating costs of $\$ 15$ per acre-foot in 1960 which would amount to more than $\$ 19$ in 1965 prices.

$9_{\text {M.W.D. has lost entitlement to } 650,000 \text { acre-feet as a result }}$ of a Supreme Court decision favoring Arizona Claims (Arizona v. California, 373 US 546 [1963]). Arizona is expected to gradually exploit her newly gained rights, utilizing the entire amount by 1990. 
to bring about 2.5 million acre-feet of Feather River water to Southern California by the year 2020. Present plans call for the project, which will cost about $\$ 2.6$ billion in capital costs alone, to begin deliveries to the Los Angeles area in 1971 (California, Department of Water Resources, 1965, pp. 158-59; 192-93). The estimated cost of Feather River water delivered to the replenishment district is $\$ 65.00$ an acrefoot. Since the Metropolitan Water District is committed to the purchase of Feather River water, the marginal social cost of imported water is $\$ 65.00$ an acre-foot. Thus, the current price charged by the M.W.D. falls far short of marginal social cost.

In this connection, it is argued, following Hirshleifer et al. (1960, pp. 295-351) that construction of the California Aqueduct is premature. An increase in the price charged by the M.W.D. to reflect the social cost of additional water would have served as an effective rationing device for existing supplies--a device that might have forestalled the construction of the California Aqueduct for many years. As argued earlier, the use of water is not insensitive to changes in price. Thus an increase in the price of water and elimination of what is probably a discriminatory price policy would have eliminated the use of water for purposes that have a low marginal value in use. The extensive use of Colorado River water for irrigation provides a case in point. Moreover, many business firms in the Los Angeles area use water for cooling purposes on a once-through basis, a practice that is economically justified from the standpoint of the producer at 
existing prices. Finally, if a higher value is given to water, reclamation of sewage and purchase of water now being used for irrigation in the Imperial Valley become feasible alternative sources of supply (Hirshleifer and Milliman, 1967, p. 176).

The real problem of overbuilding capacity and the resulting misallocation of resources arises out of the failure to take into account the importance of price as a rationing device. Such terms as water "requirements" and water "shortage" are used without explicit reference to marginal cost but implicitly refer to current prices-prices that are well below marginal social costs. In fairness to the California Water Plan, however, it should be pointed out that the legal doctrine of appropriation provides an incentive to overexpand capacity (Gaffney, 1967, p. 194). Under the doctrine of appropriation municipalities and other entities acquire water rights by use (Hardy, 1966, p. B-15). The earliest user of a water source gains preference over other potential users. Southern California has undoubtedly been enticed by this doctrine to provide for its future "needs" by laying early claim to Northern California water.

It is concluded, then, that under present conditions, M.W.D. water is underpriced. This results in a higher level of water use than is economically justified and provides an incentive to expand supplies prematurely. A corollary to this proposition is that the M.W.D.'s differential pricing policy can be justified only insofar as price differences represent differences in true costs. 
Conjunctive Use and the Transfer of Water Rights

The preceding two sections discussed the private and social costs of the two most important sources of water in the West and Central Basin Replenishment District--ground water and imported Colorado River Water. A principal conclusion is that the marginal private cost of ground water which was estimated to be $\$ 16.00$ per acre-foot, is substantially below the $\$ 40.50$ or $\$ 41.00$ paid for an acre-foot of M.W.D. water. Such a cost differential can persist because adjudication, in addition to setting maximum production levels in each basin, has established property rights to ground water.

Establishing adjudicated rights would provide an extremely inefficient allocation among users if it were not for the existence of some mechanism to transfer water rights. A holder of ground-water rights, like any other user, has incentive to carry production up to the point where his marginal cost is equal to his marginal value in use. If, on the one hand, his rights are more than sufficient to produce at this level, it would be to his advantage to leave some of his rights unutilized. On the other hand if his rights are not sufficient to produce at this level he would be forced to curtail production at a point where the marginal value in use exceeded the marginal private cost of an increment of ground water. Further, new firms entering the District or those without water rights would be forced to purchase M.W.D. water at a greater cost and hence the marginal value of an increment of water to them would exceed the marginal value to those 
with access to the cheaper water. As economic efficiency requires that marginal values in use be equal at the margin for all users, such a sys tem represents an inefficient allocation of water.

As demands change over time the rigidity built into the distribution of ground-water production by adjudication leads to an increasingly inefficient allocation. Moreover, there is a tendency towards underutilization of ground water as those with expanding demands cannot meet these demands by increasing their production of ground water and those with a decreasing demand simply fail to utilize their rights.

Fortunately, there does exist a mechanism for the temporary transfer of rights in each basin in the form of an exchange pool. Furthermore, it is possible to enter into long-term leasing of water rights or to purchase and sell rights on a permanent basis. Accordingly the operation of the two exchange pools are discussed separately below. A few comments are then added on the permanent sale of rights.

\section{West Basin Exchange Pool}

Owners of adjudicated rights in the West Basin who have access to imported water must offer to the pool each year the amount by which each party's adjudicated right exceeds one-half of his estimated total required use of water in the ensuing year (Ostrom, E., 1965, p. 340). The price at which the releasing party offers such rights must not 
exceed the price that he would have to pay to obtain M.W.D. water delivered through the West Basin Municipal Water District. In addition, those with excess rights in any year may voluntarily offer them for sale to the exchange pool. However, the pool purchases rights offered under the mandatory provision before accepting any that are voluntarily offered. The pool accepts offers on the basis of the lowest prices and sells rights at the average price of all offers accepted. Historically more water rights have been offered to the pool than have been demanded by purchasers. In the water year 1967, for example, ten parties offered rights to 19,777 acre-feet under the mandatory provision and two parties voluntarily offered rights to 858 acre-feet. Reques ts for rights, however, totaled on $7 y 335$ acre-feet. The excess supply of rights has meant that prices paid by the pool have been less than the cost of M.W.D. water by more than the cost of pumping and the pumping assessment. The average price for the 335 acre-feet of rights purchased in the 1967 water year was $\$ 13.97$. Thus the purchaser of rights paying the pumping assessment of $\$ 6.20$ and having an average pumping cost of $\$ 9.80$ (including capital recovery) was enabled to produce ground water at a cost of $\$ 29.97$ an acre-foot as compared to the cost of $\$ 40.50$ for an acre-foot of water purchased from the M.W.D. 


\section{Central Basin Exchange Pool}

Arrangements for the transfer of water rights in the Central Basin are somewhat different. Owners of adjudicated rights who have M.W.D. facilities available are required to offer a portion of their rights to the exchange pool at a price $\$ 2$ per acre-foot higher than the difference between the cost of M.W.D. water and the cost of ground water (0strom, E., 1965, p. 502). In fiscal 1967, the price paid for rights was $\$ 26.80$ per acre-foot. ${ }^{10}$ Adding the $\$ 16.00$ per acre-foot estimate of ground-water production cost, the cost of ground water produced by the purchase of rights in the Central Basin was $\$ 42.80$ compared to the $\$ 41.00$ purchase price of M.W.D. water. In the 1967 water year, 25,731 acre-feet of rights were offered under the mandatory provision and 372 acre-feet were offered voluntarily at the same price. Eighty-eight parties purchased 11,624 acre-feet of these rights (personal interview with Max Bookman, Bookman and Edmonston, Consulting Engineers, Los Angeles).

\section{Transfer of Rights and Economic Efficiency}

To appraise the operation of the two exchange pools, assume that two producers $A$ and $B$ are confronted by identical demand curves

\section{${ }^{10}$ This price was calculated as follows:}

Central Basin Municipal Water Dist. Filtered \& Soft Water Price $\$ 47.00$

Plus

Less Agreed Average Pumping Cost

Less Pumping Assessment

Net Cost of Rights Purchased from Central Basin Pool

2.00

$-10.00$

$-6.20$ 
for water and that the marginal cost to each producer is constant and equal to that of the other producer. Suppose further that $A$ has rights to $Q_{A}$ acre-feet, whereas $B$ has rights to $Q_{B}$ acre-feet. This is the situation depicted by Figure 4-6. Producer $A$ is forced to curtail his use of ground water at a point where the value to him, $P_{A}$, exceeds the cost of an additional unit, whereas $B$ will produce to the point $Q_{B}{ }^{\prime}$, since the value to him of additional water is less than its cost. Therefore, $B$ could benefit by selling rights to $Q_{B}-Q_{B}{ }^{\prime}$ acre-feet of water at any price greater than zero. It would be to A's advantage in this case, however, to induce $B$ to give up rights to a greater quantity of water than $Q_{B}-Q_{B}{ }^{\prime}$, as adding an amount $Q_{B}-Q_{B}{ }^{\prime}$ would leave $A$ at $Q_{A}{ }^{\prime}$ a position where the value of an additional unit $P_{A}{ }^{\prime}$ is still greater than its cost. The effect of such an offer is to raise the marginal cost to both $A$ and $B$; to $A$ since it raises his actual unit cost and to $B$ since it raises his opportunity cost. The common marginal cost is the original marginal cost $M C_{p}$ plus the unit price of the offer.

Given their conmon demand curve, an optimal solution occurs when cost is bid up to $M C_{P}{ }^{\prime}$ and both parties are using $\bar{Q}=\frac{Q_{A}+Q_{B}}{2}$ acre-feet of water. At this point, the value in use is the same to each producer at the margin and the given quantity of ground water, $Q_{A}+Q_{B}$, is efficiently allocated. In increasing production from $Q_{A}$ to $\bar{Q}, A$ has paid an amount $E F G H$ for the purchase of rights 


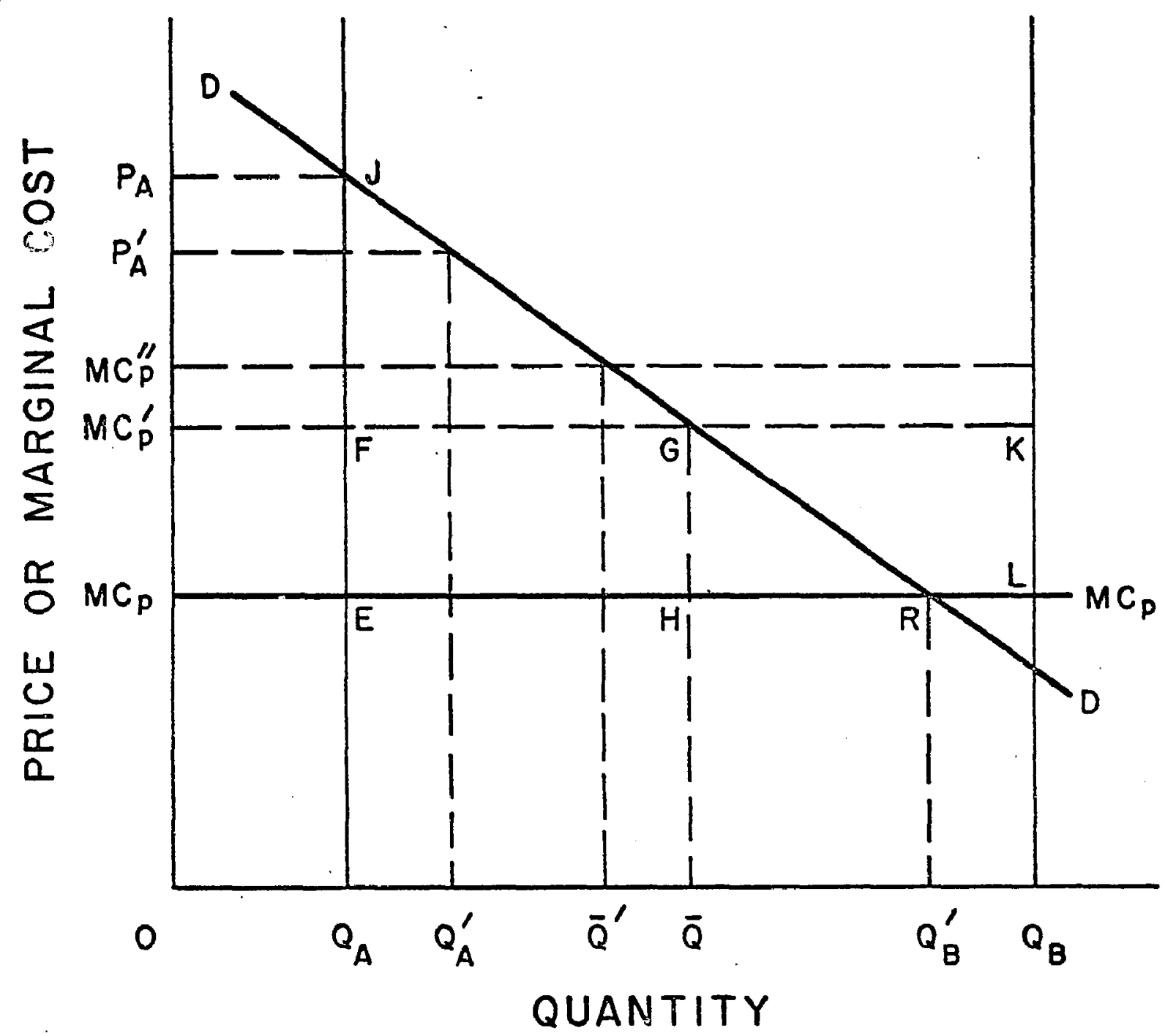

FIGURE 4-6. Transfer of Rights Through Exchange Pools 
from $B$ and incurred additional pumping costs of $Q_{A} E H \bar{Q}$. The value of the additional water to $A$, however, is $Q_{A} J G \bar{Q}$, representing a net gain to $A$ of FJG. $B$, on the other hand, has received HGKL for the sale of water rights. The net gain to $B$ is RGKL. The analys is would be much the same if $B$ had surplus rights to a greater quantity than A's deficit. However, a competitively determined price for water rights would be pushed toward zero and the quantity of water produced would be less than $Q_{A}+Q_{B}$, the total rights of both parties.

Assume now that $A$ has no rights to ground water but purchases imported water at the unit price $P_{A}$ which is higher than the cost of producing ground water. Further, let $Q_{B}$ represent the total quantity of ground water to which $B$ has a right. Now B, as before, would produce $Q_{B}$ ' acre-feet of ground water since at that point the value of an additional unit to him is equal to its cost. A would purchase $Q_{A}$ units of imported water at the price $P_{A}$, and $A^{\prime}$ 's marginal value in use is equal to the price he pays. Although each producer uses water up to the point at which its marginal value in use is equal to marginal cost, the value of the marginal unit of water is greater to $A$ than to B.

Again, it would be advantageous for $A$ to bribe $B$ to give up part of his rights to ground water. Indeed, since $Q_{B}-Q_{B}^{\prime}$ of rights have no value to $B$, he should be willing to offer them for sale at any positive price. A, on the other hand, should be willing to purchase rights at any price less than the differential between the price of 
imported water and his cost of producing ground water. As before, the marginal cost of ground water is increased to both parties--to $A$ because, in addition to the cost of production, he must pay to obtain rights from $B$ and to $B$ because the opportunity cost of retaining rights must be added to the cost of producing ground water. For the case depicted by Figure 4-6, a competitive solution would have $A$ bid the marginal cost of ground water up to $M C_{P} "$, at which $\cos t$ both $A$ and $B$ would produce $\bar{Q}^{\prime}$ acre-feet of ground water. By purchasing rights to $Q_{B}-\bar{Q}^{\prime}$ acre-feet of ground water from $B, A$ has been able to satisfy his demand for water by producing ground water at a lower total unit cost than that of imported water. Imported water would not be used at the price $P_{A}$. Oniy if the demand for water is great enough or the supply limited enough so that the price of ground water rights will be bid up to equality with the price of imported water, will imported water be used at all.

\section{Permanent Sale of Water Rights}

It was previously noted that permanent sales or long-term leases of water rights are also allowed in the Central and West Basin Replenishment District. The market for long-term or permanent rights, however, has been quite inactive (0strom, E., 1965, pp. 372-73).

A prospective purchaser should be willing to pay a total price no greater than his assessment of the present value of the future stream of net benefits that would accrue from owning the rights. 
Moreover, he should pay no more per unit than his assessment of the discounted future stream of costs of purchasing M.W.D. water including capital recovery. A potential seller should also assess the present. value to him of retaining ground-water rights. The seller's position, too, should depend on his view of discounted future net benefits as well as his forecast of M.W.D. prices.

Again, a water user with "excess" rights should be willing to sell the surplus since its value in use viewed from the present is less to him than its cost also viewed from the present. A user with "insufficient" rights also should be willing to purchase rights because the present value of the rights to him exceeds present value costs. Once more trading in rights should result in a bidding up of prices until marginal costs and marginal values in use are equated. As before the analysis also holds for an imported water user buying rights from a ground-water user.

Optimal Conjunctive Use

Allowing for the transfer of rights satisfies a necessary, but by itself insufficient, condition for economic efficiency in the District. An optimal allocation requires that (1) values in each use or to each user be equated at the margin and (2) the common marginal value in use be equal to marginal social cost. It follows that if there is more than one source of water, the entire supply is optimally allocated when the marginal social costs of both sources are 
equated provided, of course, that the first condition is satisfied.

If the District's water rights markets operated perfectly, marginal values in use and marginal private costs would be equated, but they would not necessarily be equal to the marginal social cost. Furthermore, there is evidence that the market for rights is quite imperfect, since more than one price prevails.

The deviation between marginal private and social costs is again briefly discussed in this section to clarify the existing situation. Next, market impediments in the two Basins are covered to isolate the reasons why marginal costs and values in use are not now equated. Finally, the requirements for restoring economic efficiency are discussed, and the desirability is explored of rationing groundwater rights through adjudication vis a vis using pumping charges to bring about equality of marginal costs.

\section{Social and Private Marginal Cost Discrepancy}

As noted in the preceding section, trading of water rights between water producers tends to equate marginal private costs of the trading parties. Moreover, in a perfect market, trading would take place to the point where the value of each increment would be the same in each use. If the resultant common incremental cost were achieved in the District, however, it would still deviate from the incremental cost of ground water to society.

It was previously noted that the marginal cost of ground water in the District exceeds marginal private costs by at least the total of 
the unit variable costs which are transformed into fixed costs through ad valorem taxes. This disparity is not eliminated by the trading of rights. Trading between ground-water users tends to raise marginal private cost, but social cost is increased by the same amount or more. In the long run, the private incremental cost includes pumping cost, the pumping assessment, capital recovery cost and the unit purchase price. Incremental social cost includes, in addition, the ad valorem taxes used to meet variable costs. Moreover, if trading is sufficient in amount to cause a noticeable drawdown in water levels, pumping costs must rise throughout the District and additional replenishment and barrier protection is required. Thus under present financing arrangements the gap between private and social costs tends to widen as rights are traded. The same applies to sales of ground-water rights to imported water users.

\section{Private Marginal Cost Discrepancies}

It will be recalled that different marginal costs arise out of the procedures followed by the two exchange pools. In 1967 West Coast Basin rights were purchased for a one-year period for $\$ 13.97$ per acre-foot. Addition of the pumping cost, capital recovery cost and the pumping assessment brings the total marginal private cost of this exchange poor water to $\$ 29.97$ per acre-foot. Marginal private cost for exchange pool water in the Central Basin simultaneously totaled $\$ 42.80$. 
It is seemingly paradoxical that water rights should sell for any price which differs from the cost of M.W.D. water. A little reflection, however, might yield explanations for the discrepancy. In the West Basin the only probable bidders on yearly rights are those who have wells with excess capacity. There is no guarantee that rights will continue to sell at a low price. An increase in demand could raise the yearly rights price to the M.W.D. price level, hence users who regard the low cost of rights as temporary are unlikely to drill wells. Total demand for present owners of wells with excess capacity is apparently insufficient to bid the price to equality with the M.W.D. price of $\$ 40.50 .11$

A different situation exists in the Central Basin, where in 1967 the cost of ground water purchased from the Exchange Pool appeared to be greater than the cost of the M.W.D. alternative. The cost of purchasing from the Pool was $\$ 26.80$ per acre-foot. Pumping costs, capital recovery and the pumping assessment raised the total marginal cost to $\$ 42.80$. This exceeded the M.W.D. price by $\$ 1.80$ per acre-foot. A plausible explanation for this situation is that the Central Basin Pool purchasers do not have connections to M.W.D. laterals or they would not buy the more expensive ground water.

11 The West Coast Basin requi rement that mandatory provision rights be sold first also impedes economic efficiency. The time may come when users subject to the mandatory provision will have higher values in use than the maximum price. Requiring them to sell first represents a waste if other users desire to sell lower valued rights but are prevented from doing so by the regulation. 
Central Basin water users can depend on being able to purchase ground water from the Pool at a price equal to the M.W.D. rate plus $\$ 1.80$ per acre-foot. The decision of whether or not a user would buy Pool water rather than M.W.D. water would depend, then, upon his cost of connecting to M.W.D. A decision to purchase from the Pool, uncertainty aside, requires that the present value of a connection exceed that of the future quantity evaluated at $\$ 1.80$ and reduced by the complement of the marginal corporate income tax rate $\left(T_{t}\right)$. In the notation of Chapter III, Pool purchases will be made, if for a user having a cost of capital, $k$,

$$
\begin{aligned}
\sum_{t=0}^{n}\left[K_{0}\right. & \left.+\left(1-T_{t}\right)\left(A_{t}+M_{t}\right)-S_{t}-T_{t} D_{t}\right](1+k)^{-t} \\
> & \sum_{t=0}^{n}\left(1-T_{t}\right) \$ 1.80\left(Q_{t}\right)(1+k)^{-t}
\end{aligned}
$$

where $K_{0}$ is the initial cost of a line to M.W.D., $A_{t}$ operating and $M_{t}$ maintenance cost in year $t, S_{t}$ salvage value, $D_{t}$ the depreciation allowance for the line in the $t^{\text {th }}$ year, and $Q_{t}$ the quantity of water used in year $t$.

Economic efficiency could be improved by competitive bidding. Very likely some unpurchased offers of water in 1967 had relatively low values in use to prospective sellers and the specified Pool price prevented their sale. 'Both prospective sellers and purchasers could have gained from transactions at prices lower than the agreement 
stipulated price of $\$ 26.80 .^{12}$ The existing regulation does not lead to the equating of marginal values in use or marginal costs of ground water.

A strong long-term rights market would tend to equate marginal private costs and values in use even if the Exchange Pools failed to do so. Since the market in long-term rights is quite inactive, however, it apparently does little to establish these efficiency conditions. A plausible explanation for the inactivity is that future M.W.D. prices are shrouded in uncertainty. Although it is known that future M.W.D. prices will be considerably higher, this in itself is probably insufficient to establish the firm basis required for longterm investment in ground-water rights.

Requirements for Efficiency Restoration

Assuming no change in adjudicated rights, among the changes that would have to be made to restore economic efficiency to the District are (1) the recovery of certain variable ground-water costs

${ }^{12}$ Again, social costs would be raised if additional water use, in a quantity sufficient to lower water levels, were to result from the bidding. The added social costs would have to be considered in overall efficiency calculations. 
through the pumping charge instead of ad vatorem taxes,,$^{13}(2)$ the deletion of the West Basin Exchange Pool requirement that rights be sold first under the mandatory provision, (3) a provision allowing bidding among prospective purchasers of Central Basin Exchange Pool water, which, of course, would require deletion of the agreement stipulated price and (4) receipt of a firm M.W.D. future price schedule upon which a long-term rights market could be based.

The above changes, however, would not suffice. It would remain to devise some method of adjusting ground-water production to levels that would equate marginal social costs of ground water and the M.W.D. imports. Figure 4-7 demonstrates the loss to the District, at any point in time, resulting from production of a quantity of ground-water either greater or less than the optimal amount.

The horizontal line MCS represents the marginal social cost of the supplementary supply of water purchased from M.W.D. The marginal social cost of ground water rises with production, for reasons previously outlined, and is represented by the line MCG. Aggregate demand, or marginal value in use, for the District is shown as the

${ }^{13}$ It should be recognized that M.W.D.'s current and back taxes. on property would remain in force. It will be recalled that M.W.D. is .now covering the average total cost of Colorado River Water by its direct pricing. Upon completion of the California Aqueduct the ad valorem taxes being paid will likely be used to subsidize deliveries of Northern California water. No attempt will be made in this study to determine how existing and future California Aqueduct costs should be financed, hence consideration of the effect of current M.W.D. taxes on economic efficiency is beyond the scope of this study. 


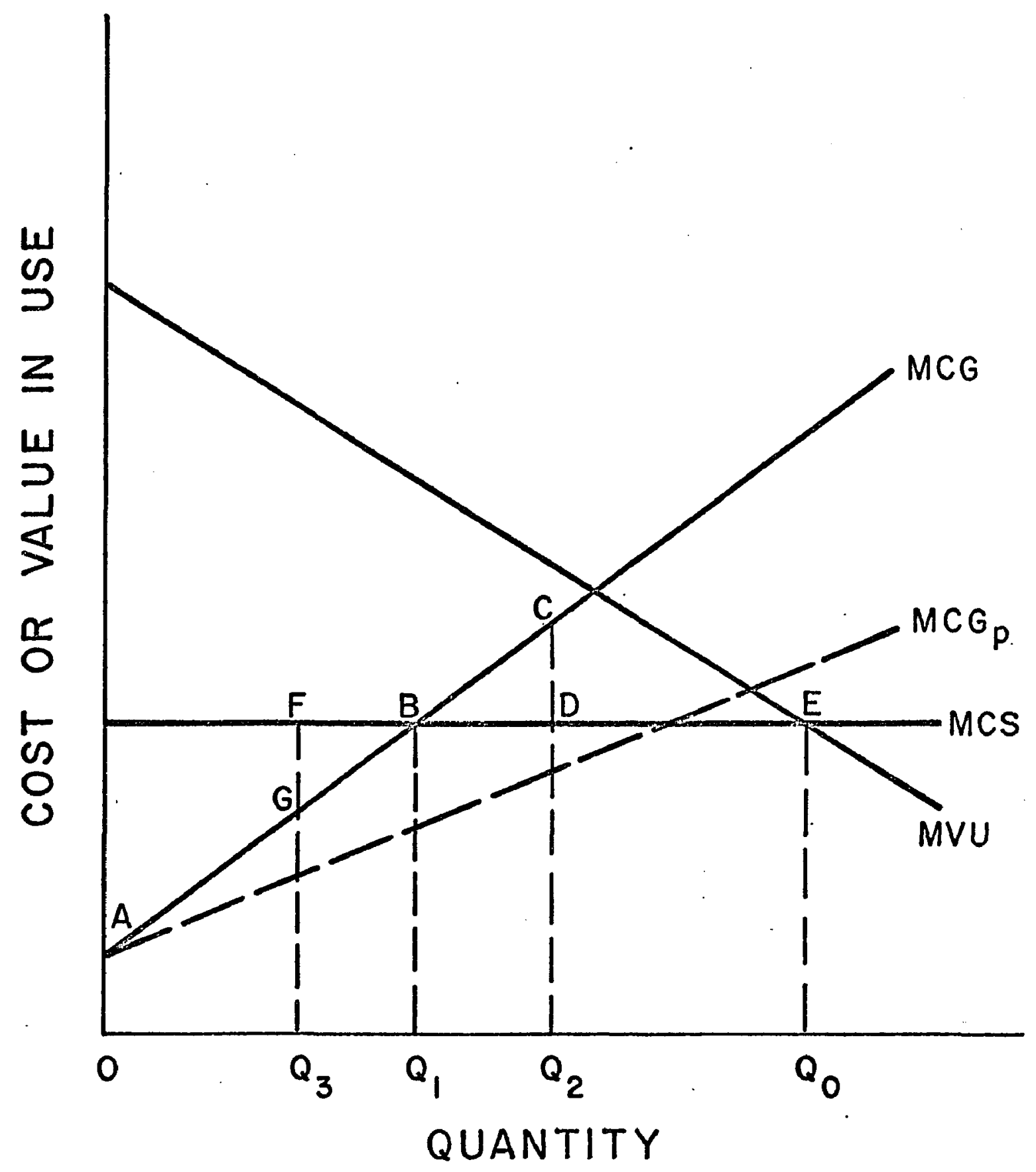

FIGURE 4-7. Losses Resulting from Overproducing or Underproducing Ground Water 
negatively sloped line MVU.

Maximum efficiency is achieved when total water use is carried out to quantity $Q_{0}, O_{1}$ of which must be ground water and $Q_{1} Q_{0}$ the total purchases of M.W.D. water. To see this suppose the amount of ground-water production to be set too high, say at quantity $Q_{2} \cdot{ }^{14}$ M.W.D. water would then be purchased in the amount $Q_{2} Q_{0}$, and total costs to society would be depicted by the areas under, the MCG curve from 0 to $Q_{2}$ and under the MCS curve from $Q_{2}$ to $Q_{0}$. This would occasion a loss to society equal to the triangular area $B C D$, since when the optimal rate of ground water is produced the social cost is only $O A B Q_{1}$ plus $Q_{7} B E Q_{0}$.

Now suppose that the allowable ground-water production is set too low, for example at the quantity $Q_{3}$. The resultant loss to society is described by another triangular area GFB, for total social cost would now be $\mathrm{OAGQ}_{3}$ plus $\mathrm{Q}_{3} \mathrm{FEQ}_{0}$.

Several aspects of the previous analysis should be made clear

${ }^{14}$ The amount $Q_{1} Q_{2}$ is produced at a social cost greater than an equivalent M.W.D. purchase; however, users would favor ground water over M.W.D. Water at aggregate output $Q_{2}$ because marginal private cost follows the dashed line MCGp, which lies below the marginal social cost curve MCG.

Note that the marginal private cost is shown to rise with output, but that this does not conflict with Figure 4-3 which shows marginal private cost to be constant. Figure 4-7 depicts aggregate demand and costs for the District whereas Figure 4-3 describes demand and cost for the individual who, by himself, does not use enough water to affect water levels throughout the District. 
at this point. First, the diagram assumes ground-water production to be set low enough to leave unsatisfied demand which can be met by purchasing a supplemental supply. It is also assumed that unrestrained ground-water production would result in a marginal social cost for ground water exceeding the unit price of the supplement. Thus, Figure 4-7 at least superficially describes the circumstances likely to prevail in the District. Next it may be noted that the analysis is static and, as such, tells an incomplete story about an essentially dynamic problem. A change in M.W.D.'s price would call for a change in the quantity of ground-water production required to meet the necessary efficiency conditions. Note, however, that under the conditions assumed, a changing demand which calls for additional total water use does not call for any change in the efficient ground-water output level. The appropriate ground-water production level is a function only of the marginal social costs of ground water and the supplementary supply. Finally, and most importantiy, it should be noted that the marginal social cost curve for ground water represents a schedule of incremental costs associated with various quantities at one instant in time only. This static marginal cost function can be quite ephemeral since the rate at which ground water is produced in one period determines the level of the cost function during the following period.

A given rate and pattern of pumpage of ground water from an aquifer will ultimately produce a steady-state condition, in which the 
piezometric surface is unchanging provided: (1) the rate of pumpage does not exceed the rate of aquifer recharge, and (2) the rate of withdrawal does not lower the piezometric surface below the top of the aquifer (personal interview, R. G. Kazmann, Associate Professor of Civil Engineering, Louisiana State University). It is clear that ground-water production in the District does not violate either of these conditions. Water levels in wells were falling prior to execution of the interim agreements, but they have since stabilized (Central and West Basin Water Replenishment District, 1966, pp. 35-38). It is equally clear, however, that no single output level could permanently satisfy the necessary economic efficiency conditions. Only if the M.W.D. price were to remain forever constant could one adjudicated output level be optimal over time.

Figure 4-8 illustrates, but greatly simplifies, the situation which has apparently developed in the Central and West Basin Replenishment District. Let $Q_{0}$ represent the production level in either Basin at a time (designated $t$ ) during the few years immediately preceding the agreed cutback in ground water production. The rate $Q_{0}$ was causing water levels to fall, therefore, if the rate had been sustained, marginal social cost functions would have shifted upward in the subsequent periods $t+1 ; t+2, \ldots$ and $t+n$. Costs would have stabilized at time $t+n$, assuming again that the two necessary conditions prevailed. The curves $M C G_{t}, M C G_{t}+1, M C G_{t+2}$ and $M C G_{t}+n$ represent marginal social cost schedules over the time range $t$ to $t+n$. 


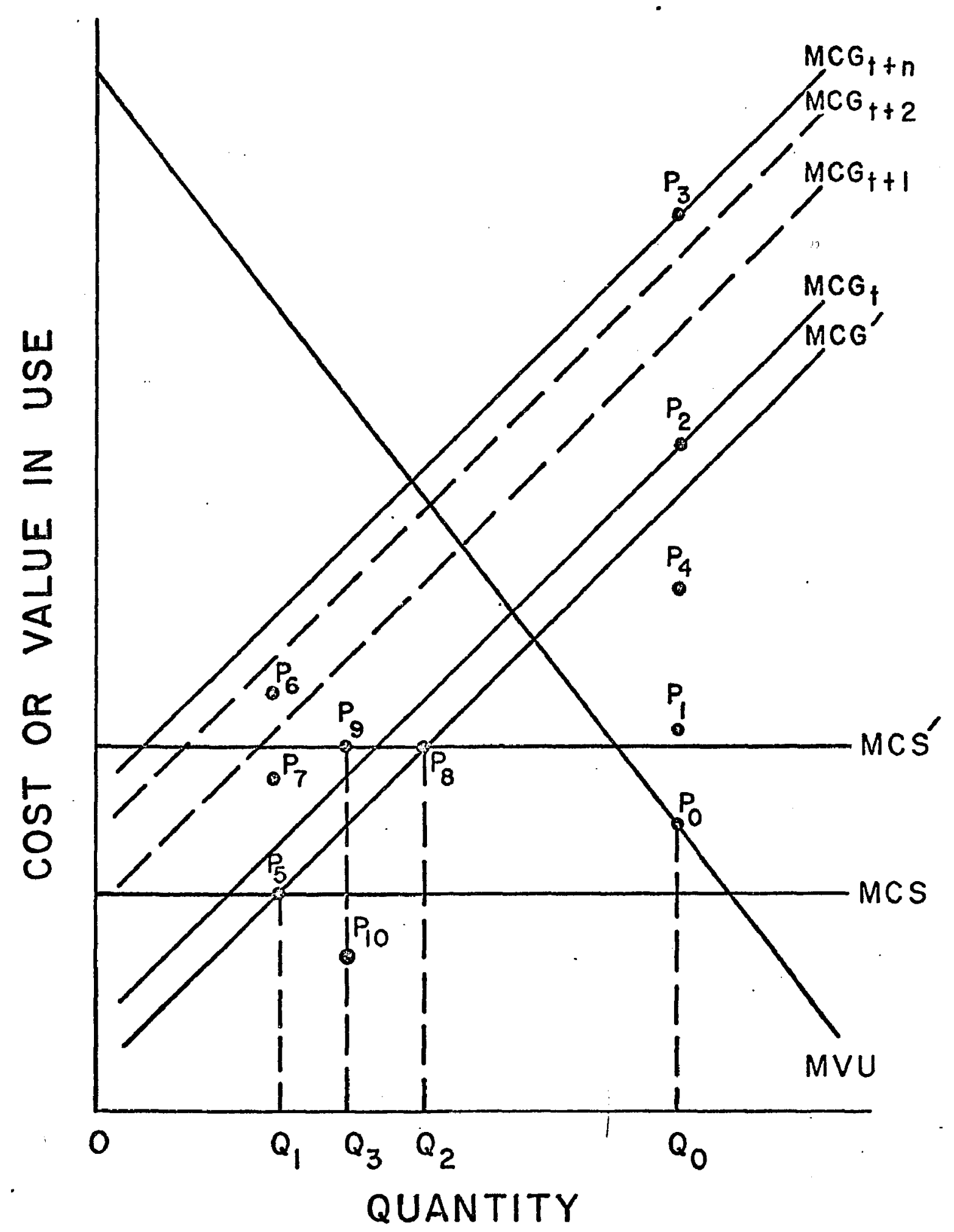

FIGURE 4-8. Ground-Water Costs at Various Output Levels 
If each pumper were maximizing his value in use, the vertical height of point $P_{0}$ would represent the marginal private cost at time t. But ground-water users, faced with litigation, were probably overproducing for a few years immediately prior to execution of the interim agreement to establish prescriptive rights (Ostrom, E., 1965, p. 312). Hence the actual marginal private cost was some point like $P_{1}$ at the going production rate. ${ }^{15}$ The marginal social cost curve would be above $P_{1}$ and rise like $M C G_{t}$. Thus the height of $P_{2}$ would represent the marginal social cost at time $t$. Upon achievement of a steady-state of water levels, the marginal social cost would have been a point such as $P_{3}$ on the curve $M C G_{t}+n$. Marginal private cost would then have been something like $P_{4}$.

While well leveis were still falling, however, the supplementary supply of Colorado River water was purchased at a constant unit price, or marginal cost, represented by the line MCS. Simultaneously, the interim agreement cutback was imposed. The new production level is represented by $Q_{1}$. This reduced rate would have resulted in downward shifting cost schedules until a new water level equilibrium was reached. ${ }^{16}$ If, by some very fortuitous circumstance, the marginal

${ }^{15}$ Note that, temporarily, the pumper would have considered his marginal value in use to be $P_{1}$ instead of $P_{0}$. The discrepancy represents the per unit amount he was willing to pay to establish prescriptive rights for the satisfaction of value in use in the future.

${ }^{16}$ Graphs of well levels in the District indicate that the actual time lag between the cutback and stabilization of well levels was about two or three years (Bookman and Edmonston, 1966, pp. 35-38). 
social cost schedule associated with the rationed rate and stabilized state were a function like MCG' with the point $P_{5}$ coinciding with the ground-water quantity and the marginal cost of imported water, a perfectly efficient "final" result would have been achieved, assuming a constant imported water price. But before the MCG' condition obtained ground water would have been over-utilized, since marginal social costs during the time lapse can be represented by the vertical coordinates of points like $P_{6}$ and $P_{7}$ which lie above the cost of the supple-mental supply, and which have related private marginal costs not exceeding the $P_{5}$ level.

Once the price of the supplemental water is increased, $Q_{1}$ no longer represents an efficient output. If, for example, the M.W.D. price were to rise to MCS', $Q_{2}$ would be the efficient rate of production, but only momentarily for this rate would now cause an upward shift in costs. The "final" efficient output would be somewhere to the left of $Q_{2}$, say $Q_{3}$ with marginal social and private costs at the levels of $P_{9}$ and $P_{10}$ respectively.

Adjudication vs. Use Charges

It follows from the preceding discussion that, as long as M.W.D.'s prices continue to change, there is no single optimal output 
level to which ground-water rights can be rationed. ${ }^{17}$ Nevertheless, it also follows that a carefully executed program of varying the levels of rationed outputs could promote economic efficiency, in principle at least. Ground-water production could be set at the precise level which would equate its marginal social cost to the prevailing M.W.D. price. Perfect allocation, however, would require continuous adjustment of rights. Each change in the M.W.D. price would result in a drifting ground-water marginal social cost schedule which would call for continual variations in output.

Alteration of adjudicated rights would pose another problem. Suppose a total production increase of a given percentage, say 25 percent, were to be effected. The increase in ground-water rights would result in an immediate efficient allocation only if the awarding of rights were based on the shape of each individual demand curve. Granting each user an increase of 25 percent would result in an improper allocation, unless there existed the most unlikely condition of identical demand curves. Figure 4-9 illustrates the problem. Let

${ }^{17}$ It is interesting to note than an economic evaluation of Los Angeles area conjunctive use by the State of California concluded that ground-water production should be increased to a considerably higher level than at present and thereafter held constant. Calculations were based on assumed stable M.W.D. prices and, therefore, are not inconsistent with this analysis though the assumptions seem questionable (California, Dept. of Water Resources, 1966, pp. 68-70). 


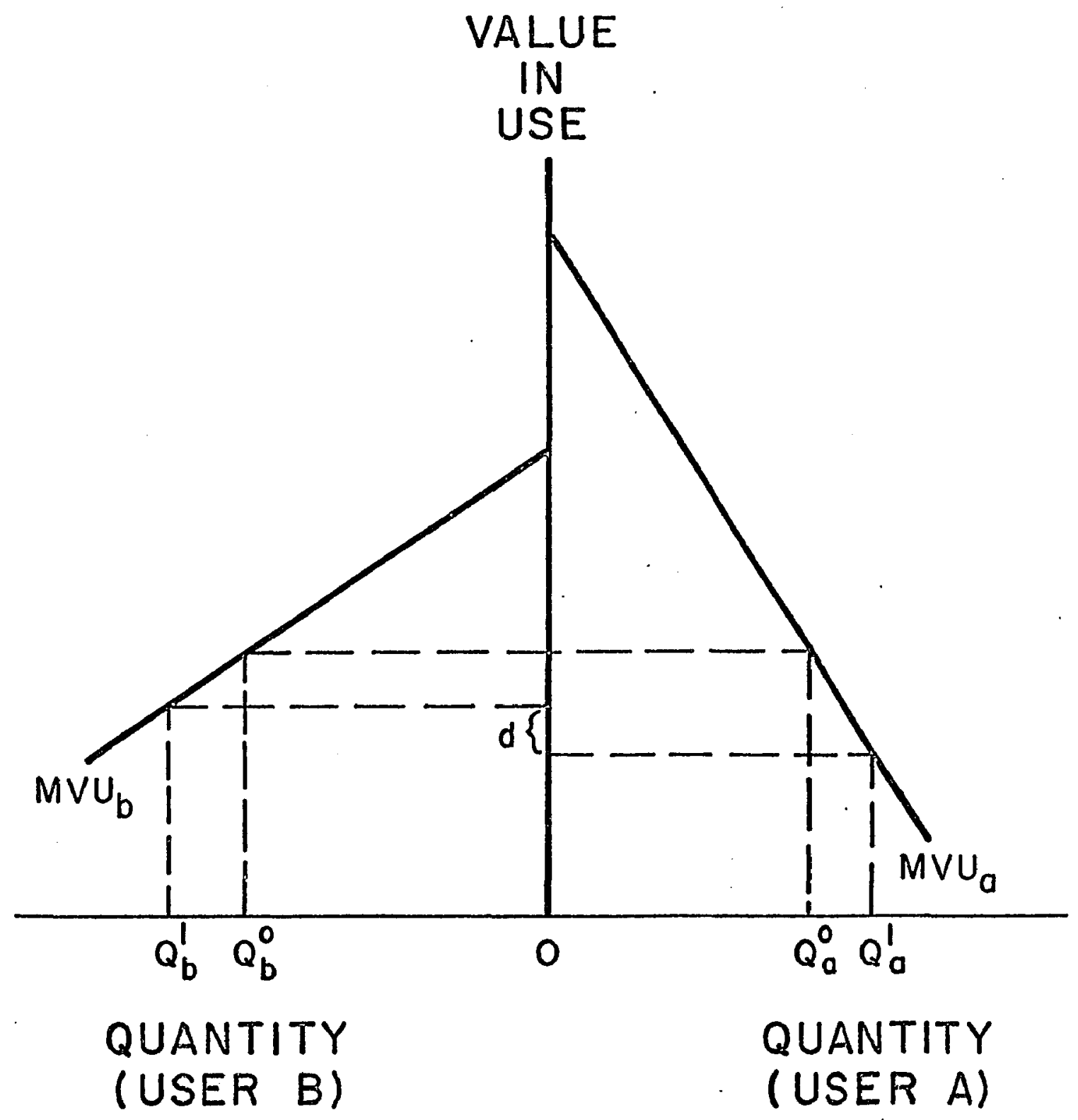

FIGURE 4-9. Immediate Effect of an Increase in Individual Ground-Water Rights 
$M V U_{a}$ and $M U_{b}$ represent demand curves for individuals $A$ and $B$ respectively. If economic efficiency had been achieved immediately prior to the event which called for a 25 percent production increase, marginal values in use would be equated and $A$ and $B$ would be pumping quantities such as $Q_{a}^{0}$ and $Q_{b}^{0}$, the latter quantity being positive but measured by the leftward distance from 0 to $Q_{b}^{0}$. Now if each were to produce 25 percent more than his original output, or quantities $Q_{a}^{1}$ and $Q_{b}^{l}$, marginal values in use would be no longer equal, the discrepancy being measured by $d$ on the vertical axis. Efficiency could be regained, but only if the market for ground-water rights were made to operate perfectly, for only then would trading take place to restore the necessary marginal conditions.

A simpler solution would eliminate adjudicated rights and ration total rights by varying the pumping charges. Figure $4-10$, which depicts aggregate production, shows how such a procedure would operate. If rights were not rationed, pumping would be carried to the point $Q_{0}$ where the marginal private cost of ground water $M C G_{p}$ equaled the price of the imported supply MCS. By assessing an additional unit pumping charge equal to $A B$ pumpage would be cut back to $Q_{1}$. As a result the marginal private cost and the marginal social costs of ground water, -MCG, would be forced into equality with each other and with the marginal social cost of the imported supply. If the supplemental supply were to rise in price to MCS', changing the additional charge to CD 


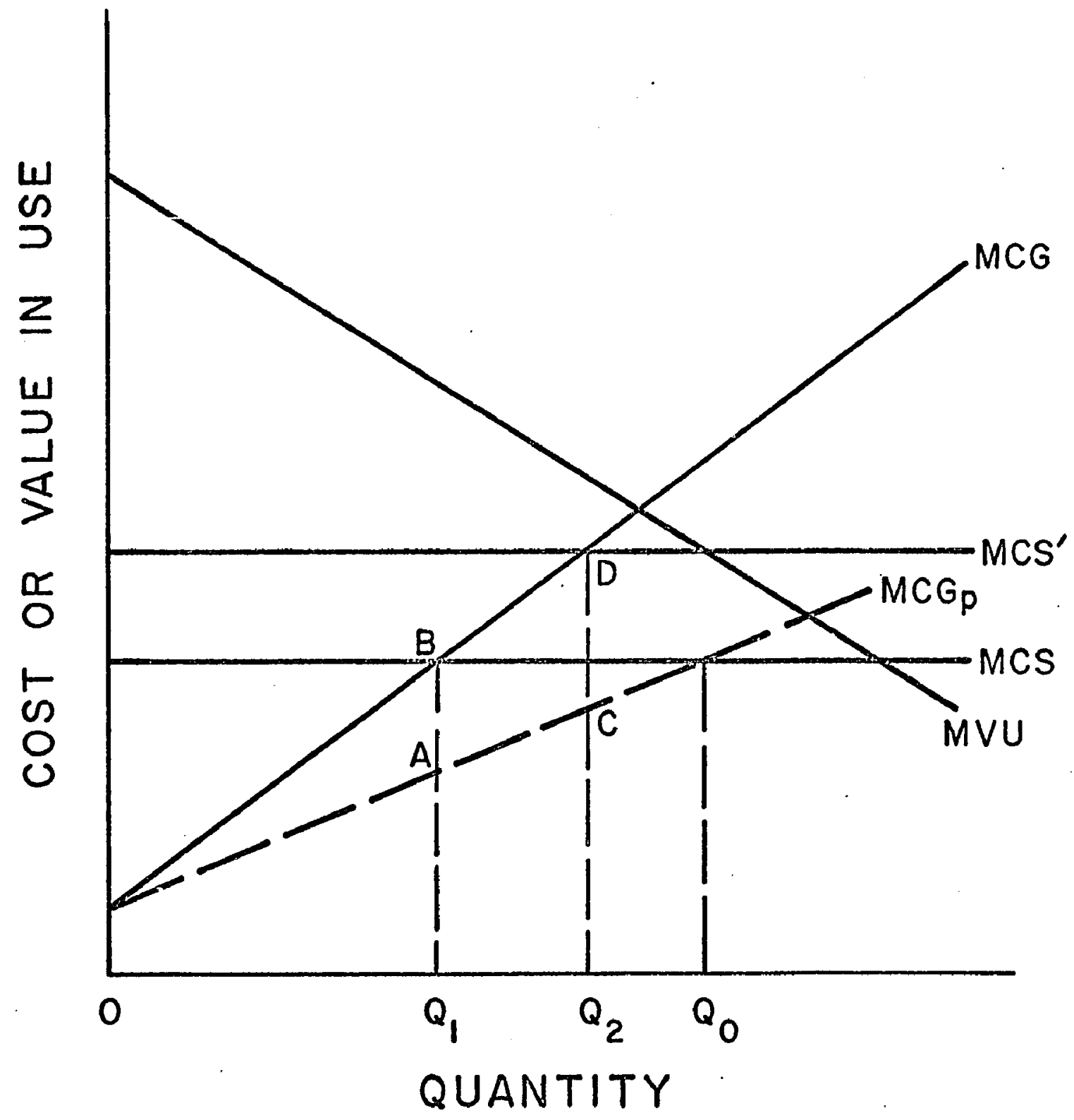

FIGURE 4-10. Rationing of Ground-Water Rights by Variations in Puniping Charges 
would satisfy the efficiency requirements. 18

Of course, constant changing of the pumping assessment would be necessary but this would be no more difficult than continually changing assigned water rights. 19 The assessments would have to be based on estimates of marginal private and social cost schedules for ground water, but these estimates would have to be made even if the rationing procedure were to involve assignment of rights. Under the assessment procedure any user would be able to produce all the water he desired. No rights would be assigned, hence, no exchange pools or other arrangements for trading rights would be needed, and the inherent market weaknesses which now prevail would no longer pose any probien. Overal1, therefore, restriction of rights through direct charges appears clearly to be the preferable procedure. In this connection Hirshleifer et al. favor establishing quota rights as a solution to the common ground-water pool problem. They consider the "use-tax" solution inadequate because of "the problem of how to determine the

${ }^{18}$ It should be noted that, in essence, the procedure recommended in this study entails marginal cost pricing, and it is therefore subject to the existing criticisms of welfare economics. In particular the problems associated with the use of consumers' and producers' surpluses to measure utility or social welfare, with "second-best" optima, and with interdependent individual utility. functions are obstacles which have not been overcome (Mishan, 1967, pp. 154-222).

${ }^{19}$ To be practical, it would probably be undesirable to change the pumping assessment more than once a year. Estimates could be made of the appropriate levels of assessment for the beginning and ending dates of the water year and a unit charge could be set somewhere between the two levels. 
marginal social cost . . "(1960, p. 66). Basically, however, their analys is is applicable only to the case where ground water is the sole water source. Once a supplemental supply exists a determination of marginal social costs is no less essential to the quota solution than it is to the pumping charge alternative.

Summary

An analysis of ground-water costs in the Central and West Basin Replenishment District discloses a significant difference between marginal private and marginal social costs. The discrepancy results from the existing practice of financing several variable costs through the use of ad valorem taxes. In effect, this transforms the variable costs into costs which are fixed from the viewpoint of the individual user. This procedure for financing costs, coupled with the existence of a higher marginal social cost of imported water and the failure of institutional arrangements to equate marginal costs, has led to misallocation of the District's water resources.

It is shown, further, that there has also been economic inefficiency associated with the District's imported supply of Metropolitan Water District water. The Colorado River Aqueduct was apparently undertaken prematurely; however, after its construction, M.W.D. seems to have been justified in its practices of price discrimination, charging less than average total cost, and recovering the deficit through ad valorem taxes. Recently, though, M.W.D. has been 
underpricing $i$ ts water. Deliveries have increased to a rate approaching the aqueduct capacity, and M.W.D. has contracted for Northern California water which will cost significantly more than its present supply. The cost of the new import is now the marginal cost which should be used as the basis for pricing the supplemental supply, but it is unlikely that much water would be sold at the very high price which would then result. Los Angeles has failed to make use of the price system for rationing its water, and, perhaps largely as a result of the appropriative water law doctrine, it has turned to a very expensive source of water when cheaper alternatives were available.

An optimal conjunctive use system, one with ground water and imported water marginal values in use equated with a marginal social cost common to both, is suggested for the District. This would require the elimination of adjudicated rights, and depend instead on assessment of pumping charges which would vary with changes in the M.W.D. price. 


\section{CHAPTER $V$}

\section{SUMMARY AND CONCLUSIONS}

The basic problem of economics is the problem of allocating society's scarce resources to the production of $i$ ts unlinited wants. The economic "problem" associated with water production is merely a subset of the overall problem. Water is frequently treated as if it were "something different," but it is in no way different from other economic goods or resources. While water is, for all practical purposes, in unlimited supply, additions to present supplies for irrigation, industrial or residential uses are subject to the laws of diminishing returns and increasing costs. Any political subdivision may increase its supply of usable water, but only if its people are willing to pay the accompanying increasing costs. The higher costs of producing water are reflected in the increasing quantities of scarce resources that must be devoted to the production of constant unit increments of water.

Economic efficiency requires: (1) that present water supplies be allocated in such a way as to make the maximum contribution to social welfare, (2) that no new water projects be undertaken unless they are warranted by the demands of society, and (3) that such new supplies as are obtained be taken from the least costly among all available alternatives. It has been the objective of this dissertation to determine whether or not these requirements are, or can be, 
met, in light of existing laws and practices. To this end, the allocation of existing ground water was examined. A decision rule for community action was then devised and some of its welfare implications were discussed. Finally the results of a case study of ground water-surface water conjunctive use were presented. The major findings of the dissertation are outlined in the remaining sections.

Allocation of Existing Water Supplies

Water law in the contiguous United States may be placed in two classifications. The first basic legal form is called the "riparian doctrine." Essentially, this doctrine holds that a landowner may use water which flows over, under or adjacent to his land, provided his use is "reasonable" as determined by the courts. The riparian doctrine is adhered to in the eastern United States. The second type of water law is called the "appropriative" doctrine. Here an individual, or political entity, gains a usufructory right to water merely by appropriating it to his use. Senior water rights develop from the earliest use; junior rights accrue to later appropriators. Appropriative water rights need not pass the test of "reasonableness" although the use of these rights must be considered "beneficial." The appropriative doctrine is widely used in the western United States. In general, it may be said that neither the riparian nor appropriative doctrines provide for firm water rights which may be sold in the marketplace. Moreover, the trend is not toward private 
ownership and tradeable water rights. Rather it is toward public ownership and administrative control of water.

Assuming perfect competition, and in the absence of external economies or diseconomies, a system of private ownership of rights and market prices will properly allocate a community's water resources. Under such conditions marginal socjal costs will be equated and equal to marginal social values in use for all uses, and the optimal conditions will be satisfied.

A number of factors, however, may prevent a system of private ownership of ground-water rights and market prices from bringing about the optimal situation. Imperfect competition, to the extent it may exist, would raise the spectre of "second best," and render the problem insoluble. Other possibilities include problems of economies of scale and external diseconomies, but these may be corrected by applying appropriate subsidies or charges to simulate the perfect market results. These subsidies and charges may be superimposed on a private ownership-tradeable rights framework. Thus whether or not the listed disturbing factors exist, a system of firm private rights and market prices would provide a basis for optimal resource allocation--something present water laws cannot accomplish, since they do not allow for transfer from low- to high-valued uses. 1

In the case study of the Central and West Basin Water Replenishment District of Los Angeles, it is suggested that private (adjudicated) water rights should be abandoned despite the fact that the law does now provide for the sale of rights. For a private rights-market 


\section{Supplementing Local Water Supplies}

Local water project investment decisions may be made by using $a^{*}$ model which incorporates benefit-cost analysis. The relevant cost is a present value unit cost obtained by discounting costs which are to be incurred over time by the community's cost of capital, or, simply, its bond rate of interest. The benefit is the present value unit cost of the best alternative to the action being considered, including that of no action. Since private water users may decide to augment their own supplies it is useful to treat the benefit as the present value unit cost of the best corporate alternative. Since corporate cost of capital is not easily measured, however, it is necessary to discount the benefit stream by a range of discount rates.

A hypothetical comparison was made between a corporate project and a non-profit community project. The results show that, assuming constant returns to scale and equality of costs of capital, the present value unit cost of water is lower for the corporate than for the community project. The divergence is caused by the corporate income tax structure. Nevertheless, the after-tax unit cost incurred

price system to achieve optimal allocation the market must be strong and active. A perfect market depends on perfect knowledge of prices. - The tradeable ground-water rights system fails to operate properly, because there is much uncertainty surrounding the price of the suplemental M.W.D. water. If the Los Angeles area could count on a firm price for $i$ ts imported water the solution of Chapter IV would give way to the tradeable property rights approach. 
by a corporation purchasing water from a community project is less than the present value unit cost of the corporate project. Hence the benefit-cost ratio is greater than unity, and the community is we 11 advised to undertake the non-profit project. This conclusion is strengthened by the differences in the costs of capital that are likely to exist. Economies of large scale production will also favor the community project. On the other hand, diseconomies of scale will tend to favor the corporate project, although it is quite unlikely that they will be found strong enough to overcome the other inherent advantages of the collective project:

From the viewpoint of national welfare, however, the local decision-making process may not be optimal. A project which is optimal from the community standpoint may misallocate some of the nation's resources. Correction of this problem can only be accomplished by making changes in the primary reason for the misallocation, the corporate income tax structure.

\section{A Case Study}

A study of the ground water-imported water conjunctive use system in the Central and West Basin Replenishment District of Los Angeles discloses a number of economically inefficient practices. -Several ground-water costs are being financed by ad valorem tax. From the user's standpoint these costs are fixed in both the short and long run, al though from the community's standpoint they are variable. This results in a portion of ground-water production being applied to 
low-valued uses. At the same time higher-valued uses are going unsatisfied. The marginal cost of water to users of imported water is considerably higher than the marginal cost of ground water. Although the District provides for the sale and leasing of ground-water rights, marginal costs, of imported water and ground water, hence marginal values in use, are not equated. Consequently, the allocation of the District's water supply is not optimal.

Provision for the sale of firmly established ground-water rights normally provides the basis for an efficient conjunctive use system. Again, such problems as may arise can be corrected by superimposing some type of charge or subsidy upon the firm rights-market price system. In the Los Angeles case, however, this procedure cannot be adopted because the ground-water rights market is weak and ineffective. The problem appears to be one of imperfect knowledge. Neither the users of ground water nor the users of imported water can accurately forecast future prices of the Metropolitan Water District, the entity that provides the imported-water alternative to ground water. A strong rights market requires an adequate knowledge of alternative prices. The absence of this condition in the District suggests that another approach should be used. This approach would eliminate individual adjudicated rights, and replace them with the right of each individual to produce as much water as he desires. Pumping charges would be assessed to bring the marginal cost of ground water to the appropriate level--the marginal cost of the imported 
M.W.D. water.

\section{An Overview}

Several important conclusions may be drawn from this dissertation. Existing water laws tend to misallocate water. The trend toward increasingly more bureaucratic control of water in the United States may only increase the misallocation. An improvement would be the establishment of firm and tradeable water rights. A market in water rights would provide the basis for efficient use of ground-water basin production. In the Los Angeles area an existing market does not properly allocate water because the area is dependent on an outside agency for its supplemental supply, and the outside agency's prices are not predictable. A locality that provides $i$ ts own supplementary water supply can make its pricing policy clear to potential customers, thus it can estab]ish this necessary condition for a strong market in ground-water rights.

A community that undertakes a project to obtain additional water supplies may take the steps that are optimal from its own point of view. The result for the nation as a whole, however, may be resource misallocation. Any corrective of this situation would depend on changes in the corporate income tax structure.

Finally a case study shows that a considerable amount of inefficiency is present in one local ground water-imported water conjunctive use system. The inefficiency is probably largely due to laws 
which reward the premature appropriation of water. One can therefore expect this misallocation of ground water to continue until the institutional setting is altered. 


\section{BIBLIOGRAPHY OF REFERENCES CITED}

Ackerman, Edward A., 1965, The general relation of technologic change to efficiency in water development and water managenient, Readings in Resource Management and Conservation, Ian Burton and Robert $W$. Kates, Editors, University of Chicago Press, Chicago, 450-67.

Arizona v. California, 373 US546 (1963). (Court Decision).

Arrow, Kenneth J., 1966, Discounting and public investment criteria, Water Research, Allen V. Kneese and Stepehen C. Smith, Editors, Johns Hopkins Press, Baltimore, 13-32.

Baumo1, W. J., 1952, Welfare Economics and the Theory of the State, Longmans, Green and Co., London, $171 \mathrm{p}$.

, 1965, WeTfare Economics and the Theory of the State, 2nd ed., Harvard University Press, Cambridge, Mass., $x+212$ p.

Bell, Neal H., 1965, Beneficial use of water, Willamette Law Journal, $\underline{3}, 382-90$.

Bierman, Harold, Jr., and Seymour Smidt, 1960, The Capital Budgeting Decision, The Macmillan Company, New York, 264 p.

Boerschinger, Thomas H., 1965, The regulation of groundwater resources, Illinois Continuing Legal Education, 3, 109-43.

Bookman, Max, 1968, Legal and economic aspects of salt-water encroachment into coastal aquifers, Proceedings of the Limited Professional Symposium on Salt-Water Encroachment into Aquifers (May 4-5, 1967), Louisiana Water Resources Research Institute, Louisiana State University, Baton Rouge, October, 1968, 169-84.

Breitenstein, Jean S., 1950, Some elements of Colorado water law, Rocky Mountain Law Review, 22, 343-55.

Bruington, Arthur E., 1968, The amelioration or prevention of saltwater intrusion in aquifers--experience in Lo: Angeles County, California, Proceedings of the Limited Profes:ional Symposium on Salt-Water Encroachment into Aquifers (May 4-5, 1967), Louisiana State University, Baton Rouge, October, 1968, 153-65.

California, Department of Water Resources, 1965, The California State State Water Project in 1965, Bulletin No. $132-65, \times x i+182 \mathrm{p}$. 
, 1966, Planned Utilization of Ground Water Basins: Coastal Plain of Los Angeles County, Appendix C: Operations and ECOnomics, Bulletin No. 104, xviii +435 p.

Carhart, Arthur H., 1959, Water or Your Life, J. B. Lippincott Co., Philadelphia, 322 p.

Central and West Basin Water Replenishment District, 1966, Annual Survey Report on Ground Water Replenishment, Bookman and Edmonston, Glendale, Calif. (Consulting Civil Engineers), $v+63 p$.

, 1967, Investment in Water System Facilities within the Central and West Basin Water Replenishment District, Bookman and Edmonston, GTendale, Calif. (Consulting Civil Engineers), $\mathbf{i}+14 \mathrm{p}$.

Cochrane, D., and G. H. Orcutt, 1949, Application of least-squares regression to relationships containing auto-correlated error terms, Journal of the American Statistical Association, 44, $32-61$.

Cohen, Jerome B., and Sidney M. Robbins, 1966, The Financial Manager, Basic Aspects of Financial Administration, Harper and Row, New York, $x i+1006 \mathrm{p}$.

Cook, John W., 1967, The investment credit-investment incentive and countercyclical tool, Taxes, 45, 227-33.

Davenport, Harbert, and J. T. Canales, 1956, The Texas law of flowing waters with special reference to irrigation from the lower Rio Grande, Baylor Law Review, 8, 138-84.

Davidson, Sidney, and David F. Drake, 1961, Capital budgeting and the "best" tax depreciation method, The Journal of Business, 34, 442-53.

Davis, Stanley N., and Roger J. M. Delliest, 1966, Hydrogeology, John Wiley and Sons, Inc., New York, $x i+463$ p.

Dean, Joe1, 1951, Capital Budgeting, Columbia University Press, New York, $x+774 p$.

DeWiest, Roger J. M., 1965, Geohydrology, John Wiley and Sons, Inc., New York, $x v+366 p$.

Donaldson, Elvin F., and John K. Pfahl, 1963, Corporate Finance, The Ronald Press Company, New York, 759 p. 
Dorfman, Robert, 1966, Basic economic and technologic concepts: a general statement, Design of Water Resource Systems, Arthur Maas, Maynard M. Hufschmidt, Robert Dorfman, Harold A. Thomas, Jr., Stephen A. Marglin and Gordon M. Fair, Harvard University Press, Cambridge, Mass., xvi ii +620 p.

Doyle, James A., 1950, Water rights in Nebraska, Nebraska Law Review, $\underline{29}, 385-415$.

Dunn, Robert M., Jr., 1967, A problem of bias in benefit-cost analys is: consumer surplus reconsidered, Southern Economic Journal, 33, $337-42$.

Durand, David, 1959, The cost of capital, corporation finance, and the theory of inves tmient: comment, American Economic Review, 49, 639-55.

Durbin, J., and G. S. Watson, 1950, Testing for serial correlation in least squares regression, I, Biometrika, 37, 409-28.

, 1951, Testing for serial correlation in least squares regression, II, Biometrika, 38, 159-78.

Eckstein, 0tto, 1958, Water Resource Development, Harvard University Press, Cambridge, Mass., xi i $\hat{i}+300 \mathrm{p}$.

Falk, L. H., and W. J. Stober, 1966, The Measurement and Comparison of Costs for Alternative Water Replacement Projects, Louisiana Water Resources Research Institute, Louisiana State University, Baton Rouge, October, 1966, ii +33 p.

Foley, Frank C., 1957, Water and the laws of nature, University of Kansas Law Review, 5, 492-98.

Forer, Lois G., 1961, Water supply: suggested federal regulation, Harvard Law Review, 75, 332-49.

Gaffney, Mason, 1967, Economic analysis of water resource problems-discussion, American Economic Review, 57, Papers and Proceedings, i92-95.

Gordon, Myron J., 1962, The Investiment, Financing and Valuation of the Corporation, Richard D. Irwin, Inc., Homewood, I17., 256 p.

Grant, Eugene L., and W. Grant Ireson, 1960, Principles of Engineering Economy, The Ronald Press Company, New York, viii +574 p.

Gross, Alan D., 1965, Condemnation of water rights for preferred uses-a replacement for prior appropriation, Willamette Law Journal, 3, 263-83. 
Ha11, Robert E., and Dale H. Jorgenson, 1967, Tax policy and inves tnent behavior, American Economic Review, 57, 391-414.

Hardy, George W., III, 1966, Handbook of Basic Water Law, Louisiana Water Resources Research Institute, Louisiana State University, Baton Rouge,, June, 1966, iv + 90 p.

Hirshleifer, Jack, James C. Dehaven, and Jerome W. Milliman, 1960, Water Supply, Economics, Technology, and Policy. The University of Chicago Press, Chicago, xij +378 .

Hirshleifer, Jack, and J. W. Milliman, Urban water supply: a second look, American Economic Review, 57, Papers and Proceedings, 169-78.

Johnson, Inc., 1966, Ground Water and Wells, Edward E. Johnson, Inc., St. Pau1, Minn., viij +440 p.

Jones, P. B., G. D. Walker, R. W. Harden and L. L. McDaniels, 1963, The Development of the Science of Hydrology, Texas Water Commission, Circular 63-03, iit 35 p.

Kazmann, Raphael G., 1965, Modern Hydrology, Harper and Row, New York, xiv +301 p.

Kirkwood, Marion R., 1948, Appropriation of percolating water, Stanford Law Review, 1, 1-22.

Knetch, Jack L., and Robert K. Davis, 1966, Comparisons of methods for recreation evaluation, Water Research, Allen V. Kneese and Stephen C. Smith, Editors, Johns Hopkins Press, Baltimore, 125-42.

Krutilla, John V., and 0tto Eckstein, 1958, Multiple Purpose River Development, Johns Hopkins Press, Baltimore, xiv $+301 \mathrm{p}$.

Linsley, Ray K., and Joseph B. Franzini, 1964, Water-Resources Engineering, McGraw-Hi11 Book Company, New York, xi+654 p.

Lipsey, R. G., and Kelvin Lancaster, 1956-57, The general theory of the second best, Review of Economic Studies, 24, 11-32. , 1959, McManus on second best, Review of Economic Studies, 26, 225-26.

Los Angeles County, 1966, Taxpayer's Guide: Tax Rates and Legal Requirements, Auditor-Controller's Office, Los Angeles, $141 \mathrm{p}$. 
Marglin, Stephen A., 1963, The social rate of discount and the optimal rate of investment, Quarterly Journal of Economics, 77, 95-111.

McKean, RoTand N., 1958, Efficiency in Government through Sys tems Analys is, John Wiley and Sons, Inc., New York, $x+336 p$.

McManus, M., 1959, Comments on the general theory of second best, Review of Economic Studies, 26, 209-24.

Metropolitan Water District of Southern California, 1938-1966, Annual Report for the Fiscal Year, Los Angeles (37 reports), paging varies.

Milne, Clinton, 1968, The hydrogeologic setting in Los Angeles County, California, Proceedings of the Limited Professional Symposium on Salt-Water Encroachment into Aquifers (May 4-5, 1967), Louisiana Water Resources Research Institute, Louisiana State University, Baton Rouge, October, 1968, 127-44.

Mishan, E. J., 1962, Second thoughts on second best, Oxford Economic Papers, 14, 205-17.

1964, Welfare Economics: Five Introductory Essays, Random House, Inc., New York, Xv + $229 \mathrm{p}$.

, 1967, A survey of welfare economics, 1939-59, Surveys of Economic Theory: Volume I, Money, Interest, and Welfare, St. Martin's Press, New York, xi $+222 \mathrm{p}$.

Modigliani, F., and M. H. Miller, 1958, The cost of capital, corporation finance and the theory of investment, American Economic Review, 48, 267-97.

0'Conne11, Jeffrey, 1962, Iowa's new water statute--the constitutionality of regulating existing uses of water, Iowa Law Review, $\underline{47}, 549-636$.

0strom, Elinor, 1965, Public Entrepreneurship: A Case Study in Ground Water Management, Unpublished Ph.D. Dissertation, University of California, Los Angeles, xix $+609 \mathrm{p}$.

Ostrom, Vincent, 1953, Water and Politics: A Study of Water Policies and Administration in the Development of Los Angeles, Haynes Foundation, Los Angeles, xvi ii +297 p.

Pigou, A. C., 1962, Economics of Welfare, 4th ed., St. Martin's Press, New York, $x \times \overline{x i}+876$ p. 
Samuelson, Paul A., 1958, Foundations of Economic Analysis, Harvard University Press, Cambridge, Mass., xi $+447 \mathrm{p}$.

Sen, A. K., 1961, On optimizing the rate of saving, Economic Journal, $71,479-96$.

Sleeman, J.F., 1955, The economics of water supply, Scottish Econornic Journal of Political Economy, 2, 2;1-45.

Smith, Adam, 1776, The Wealth of Nations, The Modern Library Version (1937), New York, $7 x+976$ p.

Stober, W. J., and L.H. Falk, 1967, A benefit-cost analysis of local water supply, Land Economics, 43, 328-35.

Stober, William J., L. H. Falk, and Robert E. Ekelund, Jr., 1968, Cost bias in benefit-cost analysis: comment, Southern Econonic Journa ], 34, 563-68.

Todd, David K., 1959, Ground Water Hydrology, John Wiley and Sons, Inc., New York, xi i $+336 \mathrm{p}$.

Trelease, Frank J., 1957, A model state water code for river basin development, Law and Contemporary Problems, 22, 307-22.

Tullock, Gordon, 1964, The social rate of discount and the optimal rate of investment: comment, Quarterly Journal of Economics, 78, $331-36$.

U.S. Department of Labor, Bureau of Labor Statistics, 1967, Employment and Earnings Statistics for States and Areas, 1939-66, U.S. Government Printing Office, Washington, D.C., 1xiv +812 p.

U.S. Geological Survey, 1962, Estimated lise of Water in the United States, 1960, Circular 456, K. A. Mackichan and J. A. Kemmerer, U.S. Government Printing Office, Washington, D.C., iv $+26 p$.

, 1963, The Role of Ground Water in the National Water Situation, Water Supply Paper 1800, C. L. McGuiness, U.S. Government Printing Office, Washington, D.C., $x i j+1122$ p.

Whipple, William, Jr., 1968, Economic Basis for Water Resources Analysis, Water Resources Research Institute, Rutgers University, New Brunswick, New Jersey, June, 1968, vii +116 p. 
APPENDIX

\section{WATER COST CALCULATIONS}

Average total water costs presented in Tables $4-1,4-2,4-5$ and 4-6 in the text are intended to be representative of unit costs paid by industrial firms in the Central and West Basin Water Replenishment District. Example 1 is a sample calculation for the average cost figures presented in Tables 4-1 and 4-2.

\section{Example 1.}

\section{Sample Ground-Water Cost Calculation}

Assumptions:

\begin{tabular}{|c|c|}
\hline Assessment Ratio & -- 45 percent (industrial property) \\
\hline Plant Valuation & $\begin{array}{l}\text {-- } \$ 10 \text { million consisting of } \$ 7 \text { million land } \\
\text { and improvements and } \$ 3 \text { million "personal" } \\
\text { property }\end{array}$ \\
\hline M.W.D. Tax Rate & $\begin{array}{l}\text { - } \$ 0.14 \text { per } \$ 100 \text { of assessed valuation on } \\
\text { all property }\end{array}$ \\
\hline Cost of Capital & $\begin{array}{l}\text { - } 7 \text { percent (before-tax)-- This is a conser- } \\
\text { vative figure which would tend to under- } \\
\text { state costs to private firms. However, it } \\
\text { is probably somewhat on the high side for } \\
\text { a municipality, hence costs may be slightly } \\
\text { overstated when the cost of capital is the }\end{array}$ \\
\hline
\end{tabular}


interest rate on municipal bonds.

Water Pumpage Rate -- 10,000 acre-feet per year

Life of Wells

-- 20 years

Cost per Well

-- $\$ 10,000$ up to 200 g.p.m. or 322 acre-feet per year capacity

-- $\$ 21,000$ up to 500 g.p.m. or 807 acre-feet per year capacity

-- $\$ 42,000$ up to 1,500 g.p.m. or 2,420 acrefeet per year capacity

Unit Cost Calculation:

Pumping Cost $\$ 7.00$

Pumping Assessment (1966-67)

6.20

Ad Valorem Taxes

Assessed Valuation

$45 \%$ of $\$ 7,000,000=\$ 3,150,000$

$45 \%$ of $\$ 10,000,000=\$ 4,500,000$

Flood Control District Zone I or II

$\$ 0.05 \times 1 / 100 \times \$ 3,150,000=\$ 1,575.00$

General Fund -F.C.D.

$\$ 0.00369 \times 1 / 100 \times \$ 3,150,000=\$ 116.24$

M.W.D.

$\$ 0.14 \times 1 / 100 \times \$ 4,500,000=\$ 6,300.00$

Replenishment District

$\$ 0.0020 \times 1 / 100 \times \$ 3,150,000=\$ 63.00$

Total Ad Valorem Taxes $=\$ 7,991.24$

$\div 10,000=$ Ad Valorem Taxes/Acre-Foot

0.80 


\section{Capital Recovery Cost}

(Capital Recovery Factor--7\%,

20 Year Life $=0.09439$ )

10,000 Acre-Feet per Year Pumpage Rate Met

by Use of $1-\$ 10,000$ and $4-\$ 42,000$ wells

$\$ 178,000 \times 0.09439=\$ 16,801.42 /$ Year

$\div 10,000=$ Capital Recovery/Acre-Foot $=$ 1.68

Total $\operatorname{Cos} t /$ Acre-Foot $=$ 


\section{Example 2}

\section{Sample M.W.D. Water Cost Calculation}

Assumptions:

Assessment Ratio _- $45 \%$

Plant Valuation -- $\$ 10$ million, $30 \%$ "personal" property

M.W.D. Price $\quad$-- $\$ 40.00$ per acre-foot (1966-67 price for softened and filtered water)

M.W.D. Tax Rate $\quad$-- $\$ 0.14$ per $\$ 100$ of total assessed value

Cost of Capital -- $7 \%$ before-tax

Water Use $\quad$-- 10,000 acre-feet per year

Cost of Connection

to M.W.D. Feeder $\quad-\$ 40,000$

Unit Cost Calculation

M.W.D. Rate

$\$ 40.00$

Ad Valorem Taxes (See Example 1 Above) 0.80

Capital Recovery Cost

Assuming a Perpetual (or long) Life

$=\$ 40,000 \times 7 \%=\$ 2,800 /$ year

$\div 10,000=$ Capita1 Recovery Cost/Acre-Foot $=\underline{0.28}$

Total Cost/Acre-Foot $=\quad \$ 41.08$

$+\$ 0.50$ to West Basin Municipal Water District $=\$ 41.58$ 
VITA

Laurence Henry Falk, son of Harry A. and Marie Falk, was burn in Ft. Collins, Colorado, on March 25, 1929. He was graduated from the St. Francis de Sales High School in Denver, Colorado in 1946. In September, 1946, he enlisted for a two-year term in the United States Army. The second year of his service was spent with the Army Advisory Group in Nanking, China. He was honorably discharged in September, 1948, holding the rank of corporal.

In January, 1949, he enrolled in the University of Denver where he studied a Business-Engineering curriculum and majored in Economics. He was awarded the degree of Bachelor of Science in August, 1952.

From 1952 to 1963 he worked in industry. Eight years of that time was spent as an analyst in the crude oil purchasing department of a major oil company in Denver, Houston and New Orleans.

In April, 1963, he became a researcher on the staff of the Public Affairs Research Council in Baton Rouge, Louisiana. He left the research organization in 1965 to continue his studies in Economics and conduct research in the area of Water Resources Economics at Louisiana State University. In September, 1968, he was appointed Instructor of Economics and is presently serving in that position. He is now a candidate for the degree of Doctor of Philosophy at the May, 1969, Commencement. 
EXAMINATION AND THESIS REPORT

Candidate:

Major Field:

Title of Thesis:
Laurence H. Folk

Economics

Economic Aspects of Ground-Water Basin Control

Approved:
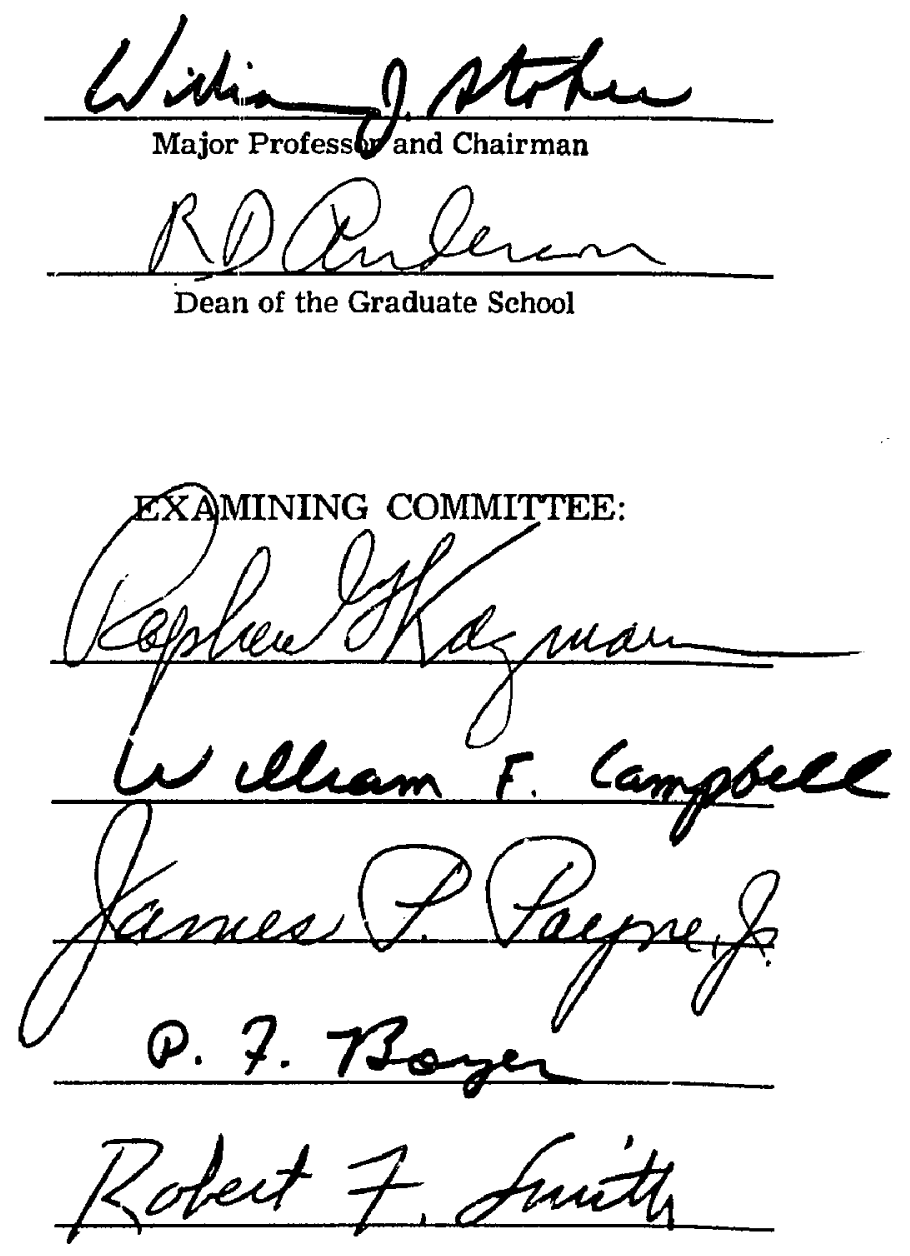

Date of Examination:

May 1, 1969 